\title{
Abrupt and moderate climate changes in the mid-latitudes of Asia during the Holocene
}

\author{
ELENA M. AIZEN, ${ }^{1}$ VLADIMIR B. AIZEN,${ }^{1}$ NOZOMU TAKEUCHI, ${ }^{2}$ PAUL \\ A. MAYEWSKI, ${ }^{3}$ BJORN GRIGHOLM, ${ }^{3}$ DANIEL R. JOSWIAK, ${ }^{4}$ STANISLAV A. NIKITIN, ${ }^{5}$ \\ KOJI FUJITA, ${ }^{6}$ MASAYOSHI NAKAWO, ${ }^{7}$ ALEXANDER ZAPF,+ \\ MARGIT SCHWIKOWSKI ${ }^{8,9}$ \\ ${ }^{1}$ Department of Geography, University of Idaho, Moscow, ID 83844, USA \\ ${ }^{2}$ Department of Earth Sciences, Graduate School of Science, Chiba University, Chiba 283-8522, Japan \\ ${ }^{3}$ Climate Change Institute, University of Maine, 133 Sawyer Environmental Research Center, Orono, Maine 04469, USA \\ ${ }^{4}$ Institute of Tibetan Plateau Research, Chinese Academy of Sciences, Beijing 100101, China \\ ${ }^{5}$ Department of Glacio-Climatology, Tomsk State University, Tomsk 634050, Russia \\ ${ }^{6}$ Graduate School of Environmental Studies, Nagoya University, Nagoya 464-8601, Japan \\ ${ }^{7}$ Research Institute for Humanity and Nature, 335 Takashima-cho, Kamigyo-ku, Kyoto 602-0878, Japan \\ ${ }^{8}$ Paul Scherrer Institute, $\mathrm{CH}-5232$, Villigen PSI, Switzerland \\ ${ }^{9}$ Oeschger Centre for Climate Change Research, University of Bern, Bern, Switzerland \\ Correspondence: Elena M. Aizen <eaizen@uidaho.edu>
}

\begin{abstract}
A multiple parameter dating technique was used to establish a depth/age scale for a $171.3 \mathrm{~m}$ (145.87 $\mathrm{m}$ w.e.) surface to bedrock ice core (B|2003) recovered from the cold recrystallization accumulation zone of the Western Belukha Plateau (4115 m a.s.l.) in the Siberian Altai Mountains. The ice-core record presented visible layering of annual accumulation and of $\delta^{18} \mathrm{O} / \delta \mathrm{D}$ stable isotopes, and a clear tritium reference horizon. A steady-state glacier flow model for layer thinning was calibrated and applied to establish a depth/age scale. Four radiocarbon $\left({ }^{14} \mathrm{C}\right)$ measurements of particulate organic carbon contained in ice-core samples revealed dates for the bottom part of Bl2003 from 9075 $\pm 1221 \mathrm{cal}$ a $B C$ at $145.2 \pm 0.1 \mathrm{~m}$ w.e. $(0.665 \mathrm{~m}$ w.e. from the bedrock) to $790 \pm 93 \mathrm{AD}$ at $121.1 \mathrm{~m}$ w.e. depth. Sulfate peaks coincident with volcanic eruptions, the Tunguska meteorite event, and the 1842 dust storm were used to verify dating. Analysis of the Bl2003 ice core reveals that the modern Altai glaciers were formed during the Younger Dryas (YD) $(\sim 10950$ to $\sim 7500 \mathrm{cal} \mathrm{a} \mathrm{BC})$, and that they survived the Holocene Climate Optimum (HCO) ( 6500 to $\sim 3600$ cal a BC) and the Medieval Warm Period (MWP) $(\sim 640$ to $\sim 1100$ AD). A decrease in air temperature at the beginning and an abrupt increase at the end of the YD were identified. Intensification of winds and dust loading related to Asian desert expansion also characterized the YD. During the YD major ion concentrations increased significantly, up to $\mathbf{5 0}$ times for $\mathrm{Na}^{+}$(background), up to 45 times for $\mathrm{Ca}^{2+}$ and $\mathrm{Mg}^{2+}$, and up to 20 times for $\mathrm{SO}_{4}^{2-}$ relative to the recent warm period from 1993 to 2003. A warm period lasted for about three centuries following the YD signaling onset of the HCO. A significant and prolonged decrease in air temperature from $\sim 2000$ to $\sim 600$ cal a BC was associated with a severe centennial drought (SCD). A sharp increase in air temperatures after the SCD was coincident with the MWP. After the MWP a cooling was followed gradually with further onset of the Little Ice Age. During the modern warm period (1973-2003) an increase in air temperature is noted, which nearly reaches the average of HCO and MWP air temperature values.
\end{abstract}

KEYWORDS: ice-core records, isotope chemistry, paleoclimatic reconstruction

\section{INTRODUCTION}

The climatic system exhibits moderate, abrupt and threshold state changes over a wide range of time. This range in variability is explored through the analysis of past climate in order to predict future climate. The retreat or advance of alpine glaciers at low-, mid- and high latitudes of Asia is one of the most obvious and significant consequences of climate variability (Haeberli and Holzhauser, 2003; Li and others, 2006; Narama and others, 2006). Over the past 150 years, since the end of the Little Ice Age (LIA), alpine glaciers all over the world have tended to retreat (Mayewski and

+ Deceased
Jeschke, 1979; Kadota and others, 1997; Paul and others, 2004; Liu and others, 2006; Aizen, 2011) in response to rapid increase of air temperature coupled with changes in precipitation patterns in mountain regions.

The rate of the glacier area change between the 1950s and 2010s varied from $-5 \%$ for large glacier massifs in the central Pamir and central Tien Shan to $-28 \%$ for small cirque and piedmont glaciers in the Siberian Altai, western and eastern Tien Shan (Surazakov and Aizen, 2006; Aizen and others, 2007; Aizen, 2011; IPCC, 2014).

Existing ensembles of climate models predict further largescale warming in central Asia (IPCC, 2014), although details of regional climate predictions for high mountain regions and 
particularly for central Asia remain unclear (e.g. Mitchell and others, 2004; UNEP, 2008). Instrumental climate records barely cover the past 100 years in Asian mountains and the data are sparse. There is still scientific uncertainty about the age of present glaciations, for example whether they existed after the Last Glacial Maximum (LGM) during the BøllingAllerød (BA) or instead developed after the interstadial BA during the Younger Dryas (YD) (Grosswald, 1980; Velichko and others, 1984, 2002; Velichko and Isayeva, 1992; Grosswald and others, 1994; Shatravin, 2000; Kuhle, 2004).

Long ice-core records from polar and alpine regions provide one of the most robust historical archives of the Earth's climate, allowing evaluation of the moderate, abrupt, and even threshold climatic conditions $\left(\mathrm{O}^{\prime}\right.$ Brien and others, 1995; Mayewski and others, 2004, 2005; IPICS, 2005). In temperate latitudes, long ice-core records can preserve records of accumulated climatic conditions extending back several millennia (Thompson and others, 1997, 2003). The goal of this research is to estimate the dynamics of moderate, and abrupt climatic changes in alpine glaciations in the mid-latitudes of Asia based on a surface to bedrock ice core from the Siberian Altai.

The Siberian Altai glacier system encompasses the continental northern periphery of the Central Asian Mountain System and the southern periphery of the Asian Arctic basin (Fig. 1) and is therefore a geographically ideal area to develop climatic records relating to major Eurasian circulation systems as well as internal and external hydrological cycles over northern Eurasia (Aizen and others, 2005). Paleo-climatic records recovered from Altai ice cores provide data that are complementary to records already developed from other Asian cores (e.g. Sentik, Dunde, Dasuopu, Guliya, Xixipangma and Everest) (e.g. Thompson and others, 1989, 2000; Kang and others, 2000; Qin and others, 2006; Tian and others, 2006). In contrast to the Tibetan/Himalayan ice-core records that have been recovered from monsoon-dominated circulation regions, the Altai Mountains act as the initial barrier in central Asia to intrusion of cold air masses from the Arctic. There have been no surface to bedrock ice-core records recovered from the Asian sector of the Arctic to compare to existing Arctic/ Greenland ice cores (e.g. Mayewski and others, 1993, 1994, 2004; Alley and others, 1997). Altai glacier records are directly associated with water vapor advected from the Atlantic and Pacific oceans and from the large AralCaspian internal drainage water system to the Arctic Ocean through Siberian rivers (Aizen and others, 2005).

\section{DATA AND METHODS}

\subsection{Field research}

The research presented here is the result of joint USA/Japan/ Russia glaciological expeditions to the Siberian Altai in 2001, 2002 and 2003 (Fujita and others, 2004; Aizen and others, 2005, 2006; Nakazawa and others, 2005; Okamoto and others, 2011). The Western Belukha Plateau at the northern edge of the central Asian mountain system was selected as the most suitable site for ice-core drilling. The plateau is $\sim 1 \mathrm{~km}^{2}$ and maintains an accumulation area of cold, recrystallized snow/firn (Aizen and others, 2005). The surface velocity at the drilling site is $<0.45 \mathrm{~m} \mathrm{a}^{-1}$. Maximum ice thickness, determined by radio-echo sounding measurements, is $180 \mathrm{~m}$. Two ice cores were drilled in 2003 on the plateau (Bl2003; 49 $48^{\prime} \mathrm{N}, 86^{\circ} 33^{\prime} \mathrm{E}, 4115 \mathrm{~m}$ a.s.l.) (Fig. 1), westward from West Belukha Peak (4435 m a.s.I.): one core was drilled to a depth of $171.3 \mathrm{~m}$ (surface to bedrock), and the second was drilled to a depth of $47.8 \mathrm{~m}$ from the surface.

An electro-mechanical drill with an inner diameter of 9.5 $\mathrm{cm}$ and a $135 \mathrm{~cm}$ long barrel (Geo-Tech Co., Japan), was used for drilling. With the $171.3 \mathrm{~m}$ borehole, the drill cutters touched bedrock. Our radar measurements of the ice thickness and bedrock topography showed that West Belukha Plateau lies on a relatively smooth flat bedrock, composed of plagiogranite and granodiorites (Berzin and Kungurtsev, 1996).

Ice-core densities and preliminary stratigraphic descriptions of ice layers and grain sizes were documented in the field via photographic and written records (Takeuchi and others, 2004). The core from the surface to $\sim 40 \mathrm{~m}$ depth consisted of a mixture of compacted firn and bubbly ice with thin transparent ice layers related to summers (Fig. 2a). The transparent layers of ice in the ice-core sections are gradually merged into a single mass of ice below $60 \mathrm{~m}$ of depth based on visual inspection.

Temperature was measured every $10 \mathrm{~m}$ in the $171 \mathrm{~m}$ deep borehole (Takeuchi and others, 2004; Aizen and others, 2006) (Fig. 2b). From $0{ }^{\circ} \mathrm{C}$ at the snow surface, temperature dropped to $-10^{\circ} \mathrm{C}$ at $2 \mathrm{~m}$, to $-15.8^{\circ} \mathrm{C}$ at $50-70 \mathrm{~m}$ depth and to $-14.4{ }^{\circ} \mathrm{C}$ at the bottom, i.e. lower than the annual mean air temperature $\left(-12.9{ }^{\circ} \mathrm{C}\right.$ for the period $1973-2003$; Aizen and others, 2005) at this elevation. The ice temperature suggests that West Belukha Plateau lies in the cold recrystallization zone, where any meltwater subsequently refreezes below the surface. Since the $-14.4{ }^{\circ} \mathrm{C}$ ice temperature at the bedrock is below the eutectic temperature, there should be no ion diffusion in the Bl2003 ice core (lizuka and others, 2012).

Bulk density of the cores increased with depth, and reached $930 \mathrm{~kg} \mathrm{~m}^{-3}$ at $\sim 60 \mathrm{~m}$ w.e. (Fig. 2c). A density/ depth profile was constructed allowing the w.e. thickness to be determined. All depths from this point in the paper are presented as w.e. depths. The ice-core length is $145.87 \mathrm{~m}$ w.e. Using insulated boxes, the ice cores were transported frozen to the ice-core laboratory at the Research Institute for Humanity and Nature (RIHN) in Japan. There, core sections were halved lengthwise and shipped frozen to the Ice Core Laboratory at the University of Idaho (UI).

\subsection{Ice-core processing and geochemical analysis}

Ice-core physical stratigraphy was conducted in the UI Ice Core Laboratory, the National Ice Core Laboratory, USA and the RIHN. After detailed stratigraphic documentation, the inner part of ice from each section $(4 \mathrm{~cm} \times 4 \mathrm{~cm})$ was cut and shipped frozen to the Climate Change Institute $(\mathrm{CCl})$ at the University of Maine (UM). At the CCI dedicated ice-core laboratory, ice-core sections were melted in a modified 'Wagenbach-style' continuous melter system connected with multiple fraction collectors to melt the core sections into discrete, co-registered samples at 0.01-0.08 m w.e. resolution (Fig. 3a, 4252 samples). The samples were immediately refrozen to await geochemical analysis. Osterberg and others (2006) provide full details of the melter system accuracy, precision and detection limits. Major ion analysis was performed via suppressed ion chromatography using a 
a

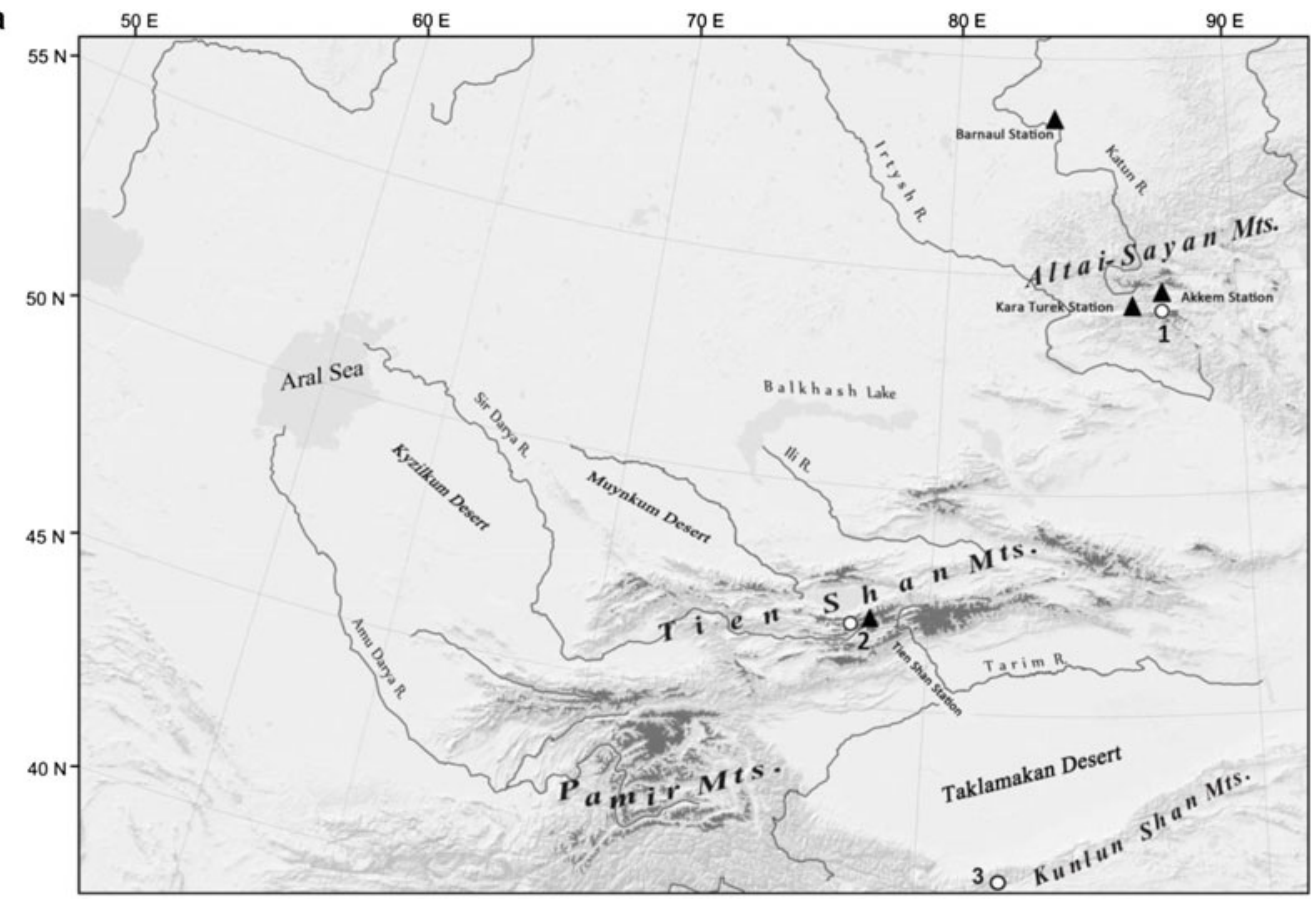

b

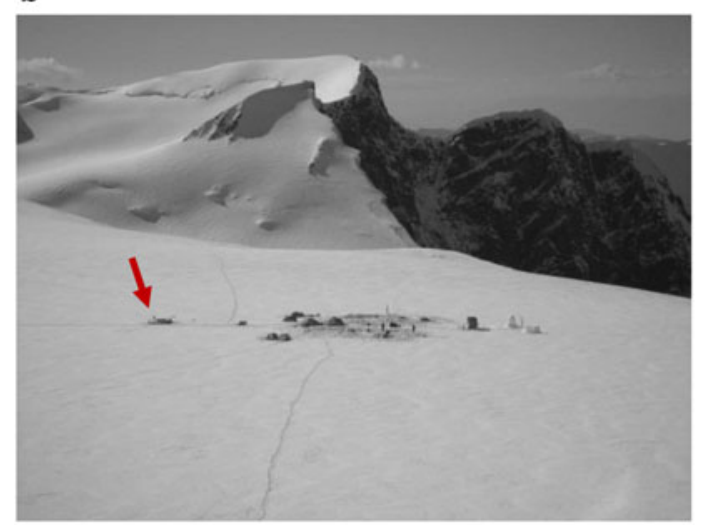

c

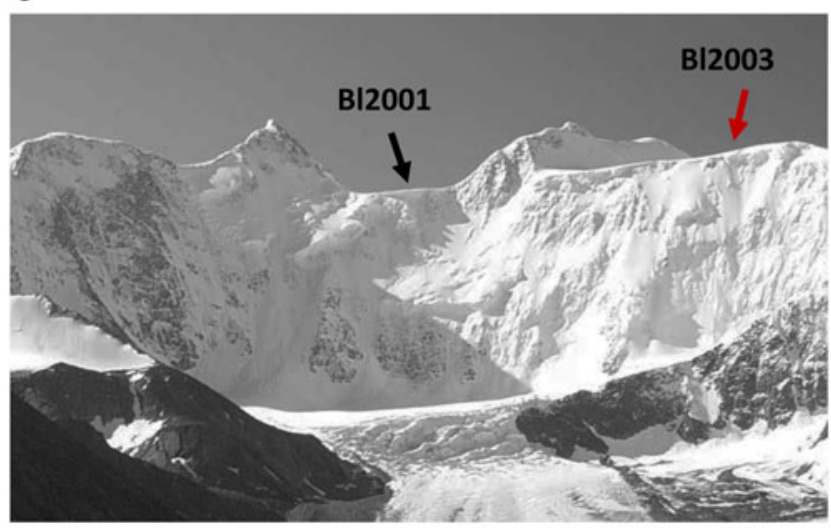

d

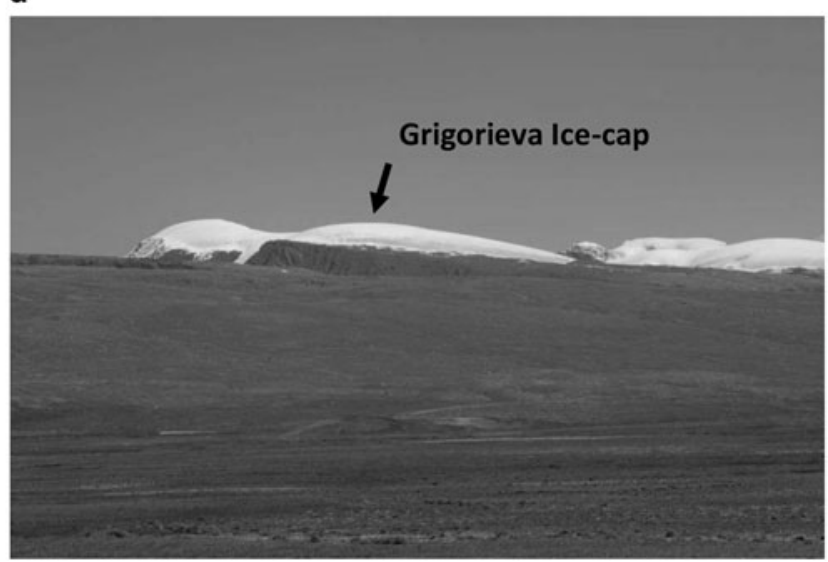

Fig. 1. (a) Map of central Asia with ice-coring sites (white circles) and meteorological stations used for ice-core records calibration and validation (black triangles). (b) Western Belukha Plateau, ice-coring site (BL2003, number 1 on the map), $4115 \mathrm{~m}$ a.s.l., August 2003, Siberian Altai. (c) Location of two drilling sites at the Belukha Mt massif: Bl2001 - between the east and west Belukha Peaks at $4062 \mathrm{~m}$ a. s.l. (Olivier and others, 2003) and Bl2003. (d) Grigor'eva ice cap in Tien Shan, (Gr2007, No. 2 on the map) at 4563 m a.s.l. (Takeuchi and others, 2014). No. 3 on the map is the ice core from the Guliya ice cap in Tibet (Thompson and others, 1997).

Dionex DX500 system at the ppb level with minimum detectable concentrations of $1 \mathrm{ppb}$.

Stable isotope ratios $\left(\delta^{18} \mathrm{O}, \delta \mathrm{D}\right)$ were determined via headspace equilibration at the UI Stable Isotope Laboratory using a Finnigan Delta Plus isotope ratio mass spectrometer coupled with Finnigan's GasBench II.
Oxygen isotope ratios were measured using a standard $\mathrm{CO}_{2}$ equilibration technique (Craig, 1957) with a Micromass multi-prep device coupled to a SIRA mass spectrometer. Hydrogen isotope ratios were measured using $\mathrm{Cr}$ reduction with a Eurovector elemental analyzer coupled to a Micromass Isoprime mass spectrometer (Morrison and 
a

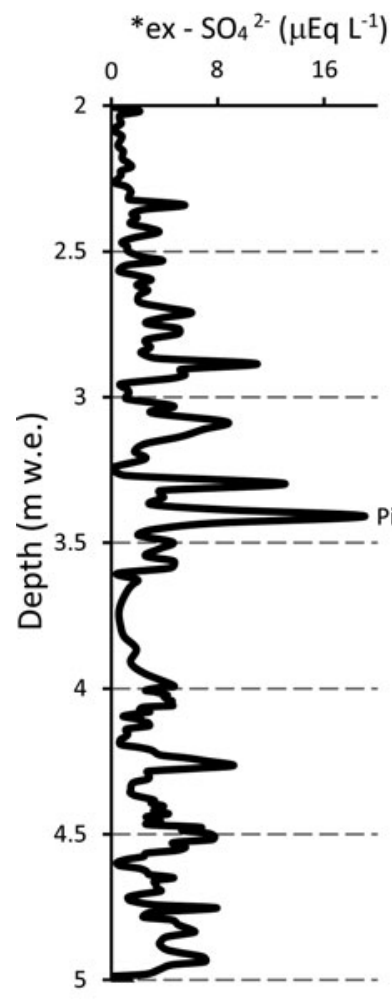

(1)

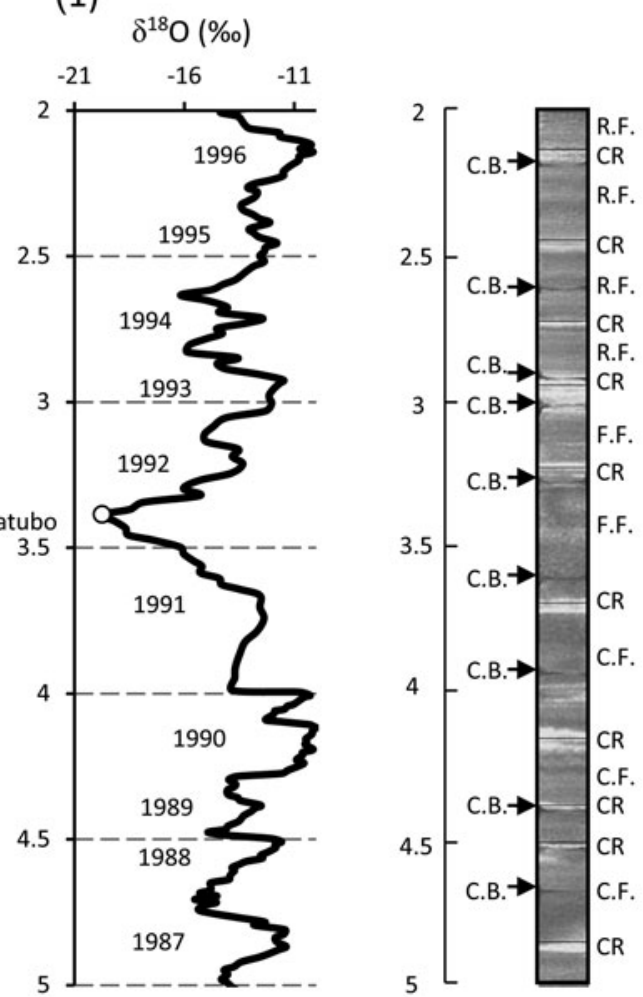

(2)
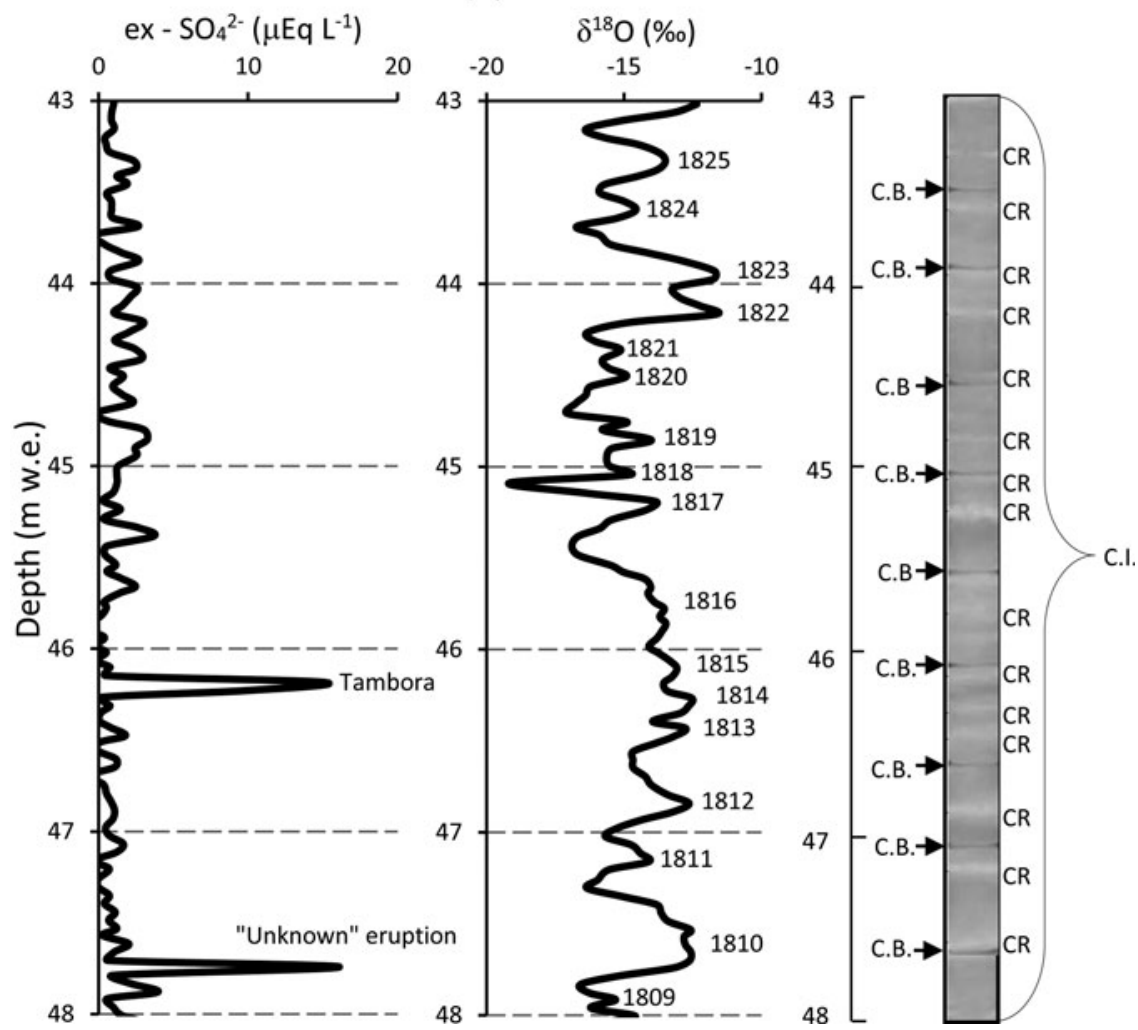

Fig. 2. Profiles of (a) *ex- $\mathrm{SO}_{4}^{2-}$, ex- $\mathrm{SO}_{4}^{2-}\left(\mu \mathrm{Eq} \mathrm{L}^{-1}\right)$, and oxygen stable isotope ratios $\delta^{18} \mathrm{O}(\%)$ seasonal-annual signals from two parts of icecore sections: from 1987 to 1997 , e.g. from 5 to $2 \mathrm{~m}$ w.e. (1) and from 1809 to1826, e.g. from 48 to 43 m w.e. (2) of BI2003 ice-core, and corresponding visual stratigraphy composed of a mosaic of digital pictures of ice-core sections: C.B signifies a break between the core sections; R.F. is regelated coarse-grained firn with few $1-2 \mathrm{~mm}$ ice crusts; F.F. is fine-grained firn with multiply $2-3 \mathrm{~mm}$ radiative ice crusts; C.F. is compact medium-grained snow/firn; C.I. is compact ice; CR is transparent ice interlayers identified compacted summer ice crusts. (b) The borehole temperature and (c) ice-core density (surface to the bedrock ice-core) (Takeuchi and others, 2004). 
b $\mathrm{T}\left({ }^{\circ} \mathrm{C}\right)$

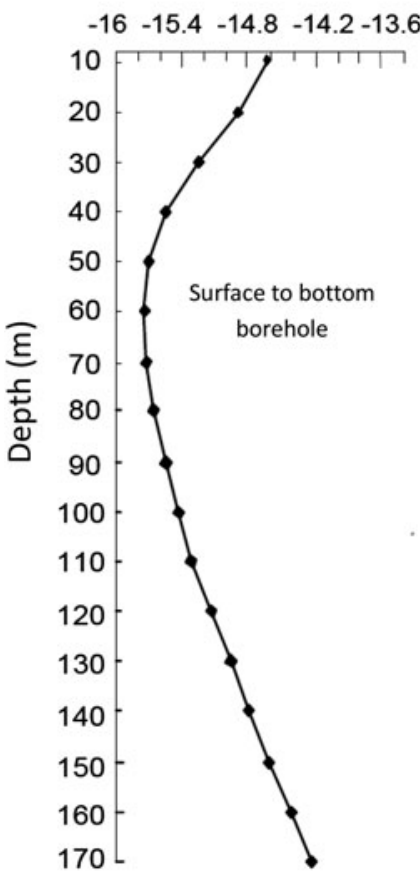

c

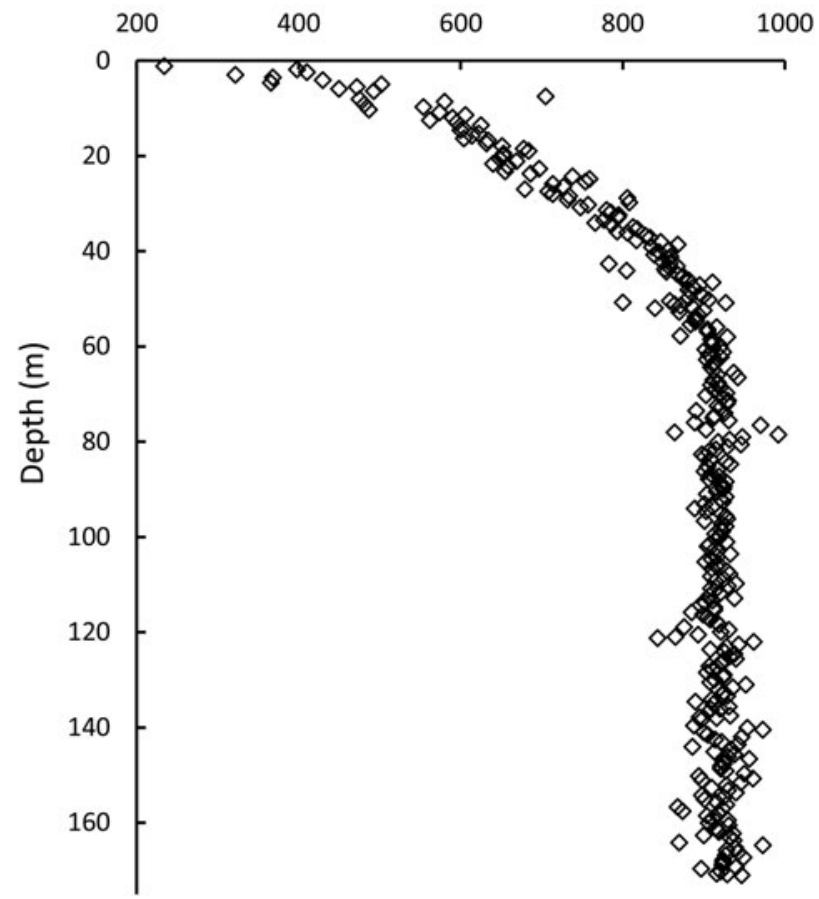

Fig. 2. (continued).

others, 2001). Data are reported in standard delta $(\delta)$ notation vs Standard Mean Ocean Water. The analytical precision for measurements of oxygen and deuterium isotope ratios was \pm 0.05 and $\pm 0.5 \%$, respectively. Analytic uncertainty in d-ex was $0.5 \%$, calculated from the quadratic average of the uncertainty for $\delta \mathrm{D}$ and $8 \times \delta^{18} \mathrm{O}$ (Froehlich and others, 2002). Stable isotope ratios $\left(\delta^{18} \mathrm{O}, \delta \mathrm{D}\right)$ determined at UI were validated with corresponding isotope data from Nagoya University (NU), Japan (Fig. 3b). UI stable isotope samples were analyzed at 0.01-0.08 $\mathrm{m}$ w.e. resolution (Fig. 3a) for the $145.87 \mathrm{~m}$ w.e. surface to the bedrock core, while NU stable isotope samples were analyzed at $0.10 \mathrm{~m}$ resolution to a depth of $68.7 \mathrm{~m}$ w.e. $(87.4$ $\mathrm{m})$ for the same surface to bedrock core. The NU stable isotope samples (1594 samples) were interpolated for validating the UI data.

\subsection{Tritium measurements}

Tritium concentrations $\left({ }^{3} \mathrm{H}\right)$ were measured via liquid scintillation counting at National Institute for Polar Research (NIPR, Japan) by analyzing 178 samples at a resolution of 0.06-0.59 $\mathrm{m}$ and verified in the Idaho State University, Environmental Monitoring Laboratory USA (ISU) by analyzing seven non coregistered samples within $1 \mathrm{~m}$ above and below the depth of maximum concentration determined at NIPR. Average difference between the four ISU samples and the NIPR results was $<13 \mathrm{TU}$, i.e. $<2 \%$ of the maximum concentration.

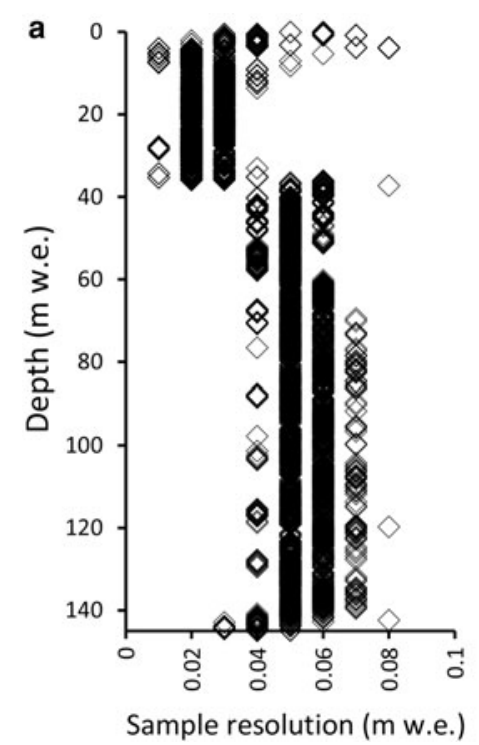

b

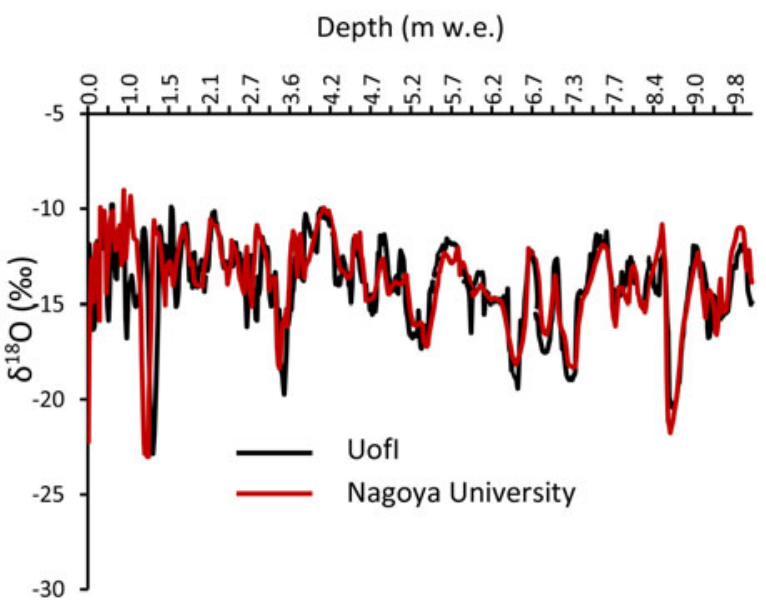

Fig. 3. The profiles of (a) sample length in the Bl2003 ice core and (b) oxygen stable isotope ratios, $\delta^{18} \mathrm{O}(\%)$. The results received in Uofl and validated with corresponding isotope data at Nagoya University. 


\section{4. ${ }^{14} \mathrm{C}$ radiocarbon measurements}

Radiocarbon analysis of the particulate organic carbon (POC) fraction was conducted at the Laboratory of Radio and Environmental Chemistry, Paul Scherrer Institute according to the method described by Jenk and others (2006) and Sigl and others (2009). Prior to analysis ice-core segments were cut in the cold room to obtain sections of clear ice. Ice layers with visible high dust loading or coarse lithoidal particles were not used for dating to avoid potential age interferences of old mineral carbon with the organic carbon fraction. Ice samples were thoroughly decontaminated by removing outer layers in a three-step process (cutting with a band saw, scraping with a scalpel, rinsing with $18 \mathrm{M} \Omega$ $\mathrm{cm}$ ultrapure water) to eliminate potential contamination from sampling and handling operations. Melted samples were then filtered through quartz fiber filters (Pallflex Tissuquartz, 2500QAO-UP; prebaked) and carbonates were removed by acidification of the filter residue with 0.2 $\mathrm{M} \mathrm{HCl}$. Dried filters were combusted in a two-step process where the fractions of POC and elemental carbon are separated $\left(10 \mathrm{~min}\right.$ at $340{ }^{\circ} \mathrm{C}, 12 \mathrm{~min}$ at $650{ }^{\circ} \mathrm{C}$ ) followed by cryogenic trapping and manometric quantification of the evolving $\mathrm{CO}_{2}$ (Szidat and others, 2004). The $\mathrm{CO}_{2}$ samples were sealed in glass ampoules, which were fixed to the gas handling system of the $200 \mathrm{kV}$ accelerator mass spectrometer system MICADAS for ${ }^{14} \mathrm{C}$ determination at the $\mathrm{ETH}$ Laboratory of Ion Beam Physics (Ruff and others, 2007; Synal and others, 2007). Results were corrected for a blank input of $1.5 \pm 0.7 \mu \mathrm{gC}$ with a fraction of modern $f_{\mathrm{m}}=0.64$ \pm 0.11 . For calibration OxCal 4.1 (Bronk, 2001) and the IntCal09 data of Reimer and others (2009) were used.

\subsection{Meteorological data}

Data from meteorological stations (daily, event, monthly and annual) for the period 1950-2002 were used for climatic analysis. The Akkem station $\left(49^{\circ} 54^{\prime} \mathrm{N}, 8^{\circ} 32^{\prime} \mathrm{E} ; 2045 \mathrm{~m}\right.$ ) has over 50 years of instrumental record, is in close proximity to the drill site (within $10 \mathrm{~km}$ ), sits at a relatively high elevation compared with other nearby stations, and is positioned to record the main air masses moving from the west toward the drill site (Fig. 1a) (Aizen and others, 2005). Barnaul station $\left(53^{\circ} 17^{\prime} \mathrm{N}, 83^{\circ} 39 \mathrm{E} ; 185 \mathrm{~m}\right)$ data were also used because that station has the longest (1838 to present) instrumental record in the region. It is located $450 \mathrm{~km}$ northwest of the drill site. An AWS installed near the drill site recorded the main meteorological parameters every $3 \mathrm{~h}$ during 2002/03 and resulting data are highly correlated with the Akkem station data. Akkem station and West Belukha Plateau temperature data for the period, July 2002 to April 2003 are also correlated, with $R^{2}=0.87$ (Okamoto and others, 2011).

Precipitation amount and simultaneous event mean air temperature were recorded hourly at the Akkem station from 21 July 2002 to 23 July 2003. Water samples from each precipitation event were collected for determination of stable isotope ratios $\left(\delta^{18} \mathrm{O}, \delta \mathrm{D}\right)$.

\section{DATING TECHNIQUES}

To establish the initial age/depth scale, we used: (1) a clear tritium peak attributed to the 1963 global atmospheric tritium maximum at the upper part of the core; (2) ${ }^{14} \mathrm{C}$ dating from discrete POC samples (at the bottom part of the core); (3) a steady-state glacier flow model for layer thinning
(Raymond, 1983; Thompson and others, 1989, 2000; Yao and Yang, 2004; Davis and others, 2005; Kaspari and others, 2008); (4) identification of seasonal signals in annual layers through analyses of stable isotope distribution to a depth of $51 \mathrm{~m}$ w.e. with discrepancy $<10 \%$ and below $51 \mathrm{~m}$ w.e. with discrepancy exceeding $10 \%$; and (5) stratigraphy to a depth of $62 \mathrm{~m}$ w.e.; below $62 \mathrm{~m}$ w.e., the discrepancy between dating by stratigraphy and by steady-state glacier flow modeling exceeds $10 \%$. Validation of dating was developed through identification of distinct layers, including significant volcanic eruptions, forest fires, the Tunguska meteorite event, and a notable dust storm in 1842 likely caused by extremely strong winds, as described in Chikhachev's journey to the Eastern Altai (Henderson and others, 2006; Malygina, 2009).

The interpolation/extrapolation between ${ }^{14} \mathrm{C}$ radioactivity marks was based on fitting a steady-state glacier flow model to the counting age/depth profile through a least-squares method, taking into account validating events.

\subsection{Tritium concentrations (Fig. 4; Table 1)}

Ice-core chronology was refined using radioactivity measurements (Naftz and others, 1996; Schwikowski and others, 1999; Pinglot and others, 2003). The analyzed tritium concentrations with depth exhibit several notable peaks consistent with past nuclear testing. The earliest tritium peak (68.5 TU at $15.49 \mathrm{~m}$ w.e.) was attributed to the first historical nuclear testing maximum in 1958, while the subsequent and largest peak (reaching $772 \mathrm{TU}$ at $14.11 \mathrm{~m}$ w.e.) was attributed to the time of maximum recorded nuclear detonations from 1962 to 1963 (Carter and Moghissi, 1977; Beck and Bennett, 2002). Five sampled radioactive horizons related to 1963 have at least three times higher values than any others with one maximum of $772 \mathrm{TU}$. The largest peak as well as minor subsequent tritium peaks (119.6 TU at $12.82 \mathrm{~m}$ w.e. and 127.4 TU at $11.04 \mathrm{~m}$ w.e.) are consistent with relative tritium concentration peaks preserved in the East Belukha (Olivier and others, 2004) during the late 1960s and early 1970s, respectively.

\section{2. ${ }^{14} \mathrm{C}$ measurements of POC (Figs 4 and $5 a$; Table 1)}

Four depths were chosen for ${ }^{14} \mathrm{C}$ measurements. The deepest measured horizon at $145.2 \pm 0.1 \mathrm{~m}$ w.e. depth $(0.665 \mathrm{~m}$ w.e. from the bedrock) corresponds to $9075 \pm 1221$ cal a BC, suggesting that Altai glaciers were formed during the YD. The next horizon at $142.8 \pm 0.4 \mathrm{~m}$ w.e. $(3.065 \mathrm{~m}$ w.e. from the bedrock) corresponds to $6197 \pm 473 \mathrm{cal}$ a BC, coincident with the sudden significant 8.2 ka cooling episode. Two other samples were obtained from the upper ice-core layers with sufficient organic carbon for radiocarbon dating. The corresponding ages were $135 \pm 221 \mathrm{cal}$ a BC at $134.6 \mathrm{~m}$ w.e. depth $(11.2 \mathrm{~m}$ w.e. above the bedrock) and $790 \pm 93 \mathrm{AD}$ at $121.1 \mathrm{~m}$ w.e. depth (26.88 $\mathrm{m}$ w.e. above the bedrock) (Figs 4 and 5a). The dated age of a ${ }^{14} \mathrm{C}$ measured layer was determined within the possible range of yearly deviation (i.e. \pm uncertainty) according to ice flow modeled dating or other corresponding historical events such as significant volcanic eruptions (Table 1).

\subsection{Stratigraphy (Fig. 2a)}

Dating of the upper ice-core sections was preliminarily assigned by counting annual (summer) layers based on 

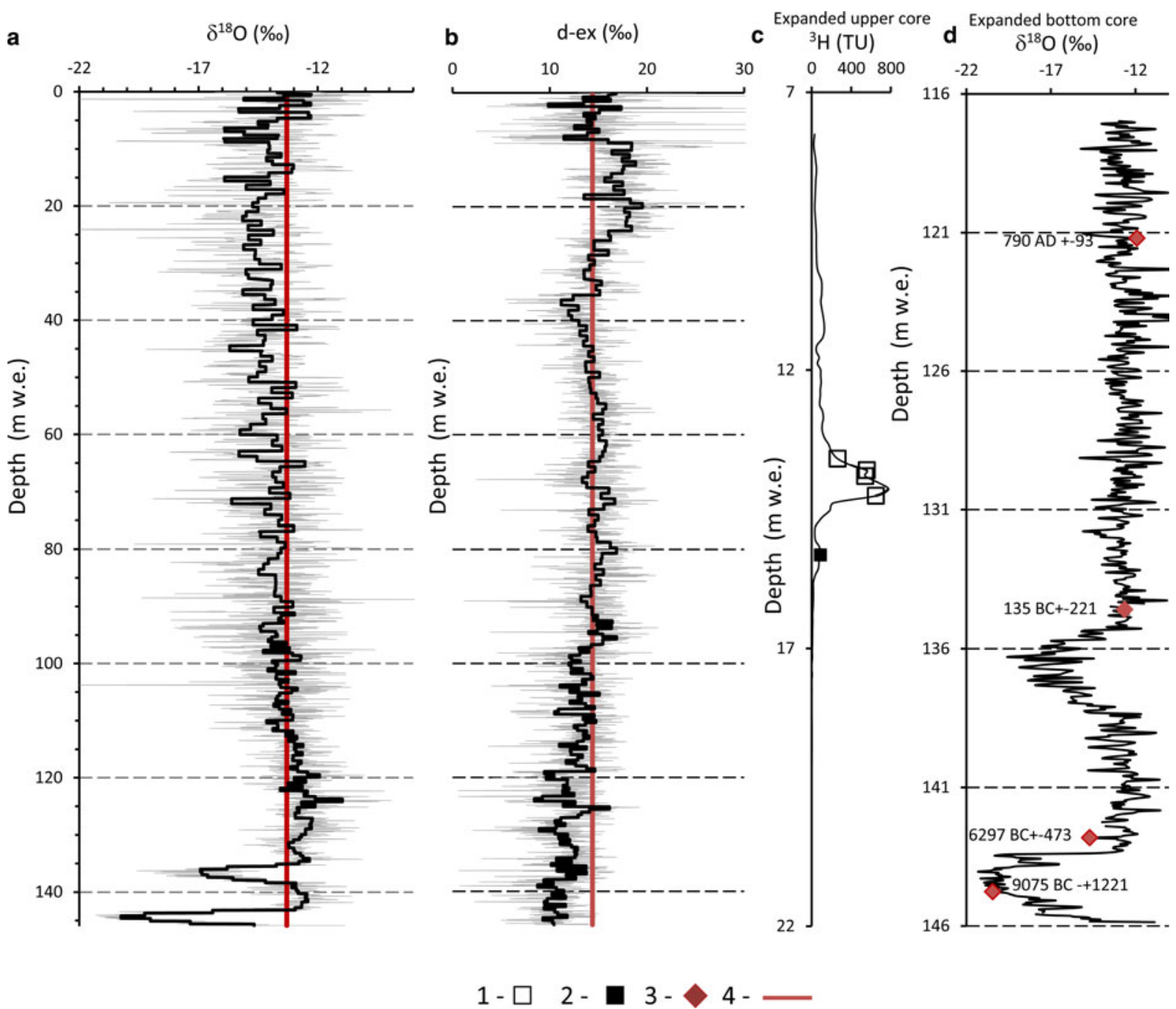

$3-$

$4-$

Fig. 4. (a) Oxygen stable isotope ratios and $1 / 0.5 \mathrm{~m}$ w.e. averages of $\delta^{18} \mathrm{O}(\%)$ and (b) d-ex (\%) from the BI2003 ice core with (c) radiogenic isotope records of ${ }^{3} \mathrm{H}$ (TU) at the top of the ice core, and (d) four ${ }^{14} \mathrm{C}$ records at the bottom of ice core. $1-{ }^{3} \mathrm{H}$ records related to $1963 ; 2-{ }^{3} \mathrm{H}$ record related to $1958 ; 3-{ }^{14} \mathrm{C}$ records; 4 - mean of $\delta^{18} \mathrm{O}$ and d-ex for ReWP.

detailed visible inspection of core stratigraphy. This technique was used successfully for the Greenland GISP2 ice core (e.g. Alley and others, 1993; Meese and others, 1997), for dating ice cores recovered from the Dunde and Guliya ice caps (Thompson and others, 1989), and also for shallow Tien Shan and Altai ice cores (Aizen and others, 2005, 2006). Due to the absence of regular/annual visible dust layers in Belukha ice cores, stratigraphic layer counting was achieved by identifying thin transparent ice interlayers related to summers radiation crusts. Melt percentage was found to be $\sim 7 \%$ in the upper $30 \mathrm{~m}$ w.e. of the core (Aizen and others, 2005; Joswiak, 2008), indicating an absence of percolation (Koerner and Fisher, 1990). Okamoto and others (2011) also reported that percolation was absent based on detailed stratigraphic analysis of ice-core layers (the upper $33 \mathrm{~m}$ w.e.) coincident with maximum air temperatures.

\subsection{Variability in stable isotopes (Figs 2a, 4, 5 and 6)}

Ice-core chronology was also refined by counting annual layers (Figs 2a and 5b) based on stable isotope variability/seasonality (e.g. Taylor and others, 1992). The $\delta^{18} \mathrm{O}$ and $\delta \mathrm{D}$ ratios were analyzed to determine the overall behavior of the stable isotope ratios with depth/time (Fig. 4). Stable isotope values in glacial cores are determined by air temperature during snowfall, seasonal distribution of precipitation, transport, mass exchange and distillation history of an air mass.

Because the Altai Mountains are located in the center of the Eurasian continent, precipitation amount during a snowfall event is not significant. Therefore, a precipitation amount effect (Dansgaard, 1964) is assumed to be absent, and distribution of stable isotope values in the ice core mainly reflects seasonal air temperature distribution (correlation up to 0.7; Aizen and others, 2006), which is notably pronounced in intercontinental regions. Identification of annual accumulation layers in the ice core was based on the extreme values of $\delta^{18} \mathrm{O}$, as minimum winter and maximum summer air temperatures, which are distinctive characteristics of the Altai meteorological regime (Aizen and others, 2005). The stable isotope records from the surface to $51 \mathrm{~m}$ w.e. (Fig. 2a) yield well preserved seasonal signals of $\delta^{18} \mathrm{O}$.

The $\delta^{18} \mathrm{O}-\delta \mathrm{D}$ relationship in the $\mathrm{Bl} 2003$ ice core reveals a similar slope to the co-variance (i.e. 8) of the Global Meteoric Water Line indicating a similar initial relationship in fractionation factor pointing to the absence of percolation in the 
Table 1. Historical events recorded in Bl 2003 ice-core from the Belukha Plateau, Siberian Altai

\begin{tabular}{|c|c|c|c|c|}
\hline $\begin{array}{l}z \\
\mathrm{~m} \text { w.e }\end{array}$ & $\begin{array}{c}\text { lons } \\
\mu \mathrm{EqL}^{-1} ; \delta^{18} \mathrm{O} \% ; \mathrm{OCppb}\end{array}$ & a/period/event & & Comments \\
\hline $0.012 ; 1.0$ & $\mathrm{~K}^{+}=8 ; \mathrm{K}^{+}=14.3$ & $\begin{array}{l}2003 \text { ff: } 73 \text { \% Siberia; } 2002 \text { ff: Yakutiya, Altai } \\
\text { kr }\end{array}$ & $\begin{array}{l}\text { Industrialization: } \\
\text { Modern (MoWP) }\end{array}$ & $\begin{array}{l}2006632 \text { ha of burned areas } \\
(15)\end{array}$ \\
\hline 3.4 & $\mathrm{SO}_{4}^{2-}=53.9 ; \mathrm{Ca} / \mathrm{SO}_{4}=0.6$ & 1991 (June) er: Pinatubo, Philippines; VEI 6 & $\begin{array}{l}\text { Recent Warm } \\
\text { Period (ReWP) }\end{array}$ & $\begin{array}{c}\text { Depleted isotopes }\left(\delta^{18} \mathrm{O}=\right. \\
-19.7 \% \text { ) after eruption }\end{array}$ \\
\hline 3.4 & $\mathrm{~K}^{+}=2.8$ & $1991 \mathrm{ff}$ & & forest fire: 1126000 ha (15) \\
\hline 14.1 & ${ }^{3} \mathrm{H}=772 \mathrm{TU}$ & 1963 max nuclear detonations & & \\
\hline 15.5 & ${ }^{3} \mathrm{H}=68.5 \mathrm{TU}$ & 1958 first nuclear detonations & & $\begin{array}{l}\text { The largest nuclear detonations } \\
1963 \text { (16) }\end{array}$ \\
\hline 16.38 & $\mathrm{SO}_{4}^{2-}=53.7 ; \mathrm{Ca} / \mathrm{SO}_{4}=0.6$ & 1956 er: Bezymianny, Kamchatka;VEI5 & & $\begin{array}{l}\text { Bl2003: Large increase in sul- } \\
\text { fates and nitrates in MoWP, } \\
\text { and they have been decreased } \\
\text { in ReWP }\end{array}$ \\
\hline $24.9 ; 26.7$ & $\mathrm{~K}^{+}=1.6 \mathrm{~K}^{+}=1.0$ & 1921 ff: Russia, Povolj'e; 1915 ff: Russia & Pre- & 12500000 ha (15) \\
\hline 27.56 & $\mathrm{SO}_{4}^{2-}=26.2 ; \mathrm{Ca} / \mathrm{SO}_{4}=0.3$ & 1912 er: Novarupta, USA; VEI 6 & industrialization & \\
\hline 28.5 & $\mathrm{NO}_{3}^{-}=18.9$ & 1908 Tunguska explosion event; Russia & & $\begin{array}{l}\text { Air burst of a large meteoroid/ } \\
\text { comet }\end{array}$ \\
\hline 35.96 & $\mathrm{SO}_{4}^{2-}=20.2 ; \mathrm{Ca} / \mathrm{SO}_{4}=0.8$ & 1883 er: Krakatoa, Indonesia;VEI 6 & Little Ice Age (LIA) & $\begin{array}{l}\text { Bl2003 depletion till the middle } \\
\text { of } 20 \text { th century }\end{array}$ \\
\hline 41 & $\mathrm{Ca}^{2+}=134.4 ; \mathrm{SO}_{4}^{2-}=22.2$ & 1842: dust storm (14) & & 1842: Extreme peaks in ions \\
\hline 45.14 & Depleted isotopes & 1816: Year without summer (13) & & BI2003: Depleted Isotopes \\
\hline 46.25 & $\mathrm{SO}_{4}^{2-}=16.1 ; \mathrm{Ca} / \mathrm{SO}_{4}=0.3$ & 1815 er. Mt. Tambora, Indonesia; VEI 7 & & $\begin{array}{l}\text { LIA began in late Medieval } \\
\text { times } 1400 \text { (10) in Europe; in } \\
1480 \text { in Siberia Teletskoe lake } \\
\text { (11); around } 1500 \text { AD in } \\
\text { China (12) }\end{array}$ \\
\hline 47.74 & $\mathrm{SO}_{4}^{2-}=22.6 ; \mathrm{Ca} / \mathrm{SO}_{4}=1.4$ & $\begin{array}{l}1809 \text { er:'unknown' or } 1800 \text { er. St. Helens, } \\
\text { USA;VEI } 5\end{array}$ & & $\begin{array}{l}\text { BI2003: Circa middle of } 15 \text { th } \\
\text { century - beginning the LIA }\end{array}$ \\
\hline 55.4 & $\mathrm{SO}_{4}^{2-}=10.0 ; \mathrm{Ca} / \mathrm{SO}_{4}=0.6$ & 1739 er: Shokotsu, Japan; VEI 5 & & \\
\hline 62.1 & $\mathrm{SO}_{4}^{2-}=7.5 ; \mathrm{Ca} / \mathrm{SO}_{4}=1.0$ & 1707 er: Fuji, Japan; VEI 5 & & \\
\hline 66.37 & $\mathrm{SO}_{4}^{2-}=11.5 ; \mathrm{Ca} / \mathrm{SO}_{4}=1.5$ & $\begin{array}{l}1667 \text { er: Shikotsu, or } 1663 \text { er. Usu, Japan; } \\
\text { VEI } 5\end{array}$ & & \\
\hline 68.9 & $\mathrm{SO}_{4}^{2-}=13.7 ; \mathrm{Ca} / \mathrm{SO}_{4}=0.4$ & $1650 \pm 10$ er: Shiveluch,Kamchatka; VEI 5 & & \\
\hline 70.2 & $\mathrm{SO}_{4}^{2-}=5.5 ; \mathrm{Ca} / \mathrm{SO}_{4}=1.0$ & 1625 er: Katla, S, Iceland; VEI 5 & & \\
\hline 71.3 & Depleted isotopes & Circa 1601 & & \\
\hline 71.59 & $\mathrm{SO}_{4}^{2-}=9.3 ; \mathrm{Ca} / \mathrm{SO}_{4}=0.4$ & 1600 er.: Huaynaputina, Perú; VEI 6 & & \\
\hline 73.9 & $\mathrm{SO}_{4}^{2-}=5.5 ; \mathrm{Ca} / \mathrm{SO}_{4}=1.0$ & 1580 er. Billy Mitchell, Bougainville; VEI 6 & & \\
\hline 84.5 & $\mathrm{SO}_{4}^{2-}=20.8 ; \mathrm{Ca} / \mathrm{SO}_{4}=0.6$ & $\begin{array}{l}1480 \text { er: St.Elena, USA VEI 5+ or } 1477 \text { er.: } \\
\text { Bardarbunga, Iceland; VEI } 6\end{array}$ & & \\
\hline 85.3 & $\mathrm{SO}_{4}^{2-}=5.7 ; \mathrm{Ca} / \mathrm{SO}_{4}=0.9$ & 1471 er: Sakura-Jima, Japan; VEI 5 & & \\
\hline 86.95 & $\mathrm{SO}_{4}^{2-}=12.4 ; \mathrm{Ca} / \mathrm{SO}_{4}=1.2$ & $1452 \pm 10$ er: Kuwae; VEI 5+ & & \\
\hline 88.04 & $\mathrm{SO}_{4}^{2-}=11.4 ; \mathrm{Ca} / \mathrm{SO}_{4}=1.3$ & 1442 er: Oshima; VEI 5 & & \\
\hline 102.3 & $\mathrm{SO}_{4}^{2-}=10.5 ; \mathrm{Ca} / \mathrm{SO}_{4}=0.7$ & 1280 er: Quiloto, Ecuador; VEI 6 & & \\
\hline 104.16 & $\mathrm{SO}_{4}^{2-}=8.7 ; \mathrm{Ca} / \mathrm{SO}_{4}=1.8$ & $\begin{array}{l}1262 \text { er: Katla, S. Iceland; VEI 5. } 1259 \text { er: } \\
\text { might be El Chichon, Mexico (9) }\end{array}$ & & \\
\hline 117.3 & $\mathrm{SO}_{4}^{2-}=9.5 ; \mathrm{Ca} / \mathrm{SO}_{4}=1.3$ & 1000er. Changbaishan, China; VEI 7 & $\begin{array}{l}\text { Medieval Warm } \\
\text { Period, MWP }\end{array}$ & $\begin{array}{l}\text { Tree ring (7) from } \\
\text { N. Fennoscandia - a warm } \\
\text { period: } 870-1100 \mathrm{AD} ;(8) \\
\text { relates the MWO Bl2003: } \\
\text { MWP: circa } 640-1100 \mathrm{AD} . \mathrm{T} \\
\text { was on average } 0.46^{\circ} \mathrm{C} \\
\text { higher than during ReWP }\end{array}$ \\
\hline 121.1 & $\mathrm{OC}=68 \mathrm{ppb}$ & $790 \pm 93 \mathrm{AD}$ & & \\
\hline 123.2 & $\mathrm{SO}_{4}^{2-}=7.2 ; \mathrm{Ca} / \mathrm{SO}_{4}=1.6$ & $800 \pm 100$ er: Churchill, Alaska; VEI 6 & & \\
\hline 123.98 & $\delta^{18} \mathrm{O}=-8.93 \%$ & Highest enriched $\delta^{18} \mathrm{O}$ corresponds to $\mathrm{MWO}$ & & \\
\hline 124.57 & $\mathrm{SO}_{4}^{2-}=8.9 ; \mathrm{Ca} / \mathrm{SO}_{4}=0.9$ & $610 \pm 50$ er: Opala, Kamchatka; VEI 5+ & & \\
\hline 126.4 & $\mathrm{SO}_{4}^{2-}=4.0 ; \mathrm{Ca} / \mathrm{SO}_{4}=2.0$ & \multicolumn{3}{|c|}{$\begin{array}{l}550 \pm 10 \text { er: Shiveluch, Kamchatka; VEI 5. } 520 \pm 10 \text { er: Haruna, } \\
\text { Japan, VEI } 4+\end{array}$} \\
\hline 130.75 & $\mathrm{SO}_{4}^{2-}=5.0 ; \mathrm{Ca} / \mathrm{SO}_{4}=1.5$ & \multicolumn{3}{|c|}{$240 \pm 100$ er: Ksudach, Kamchatka; VEI 6} \\
\hline
\end{tabular}


Table 1. (Cont.)

\begin{tabular}{|c|c|c|c|c|}
\hline $\begin{array}{l}z \\
\text { m w.e }\end{array}$ & $\begin{array}{c}\text { lons } \\
\mu \mathrm{EqL}^{-1} ; \delta^{18} \mathrm{O} \% ; \text { OCppb }\end{array}$ & $\mathrm{a} /$ period/event & & Comments \\
\hline 136.187 & $\mathrm{SO}_{4}^{2-}=11.6 \mathrm{Ca} / \mathrm{SO}_{4}=3.0$ & $\begin{array}{l}1050 \text { BC } \pm 500 \text { BC Pinatubo, Philippines; } \\
\text { VEI } 6\end{array}$ & $\begin{array}{l}\text { Severe Centennial } \\
\text { Drought, SCD }\end{array}$ & $\begin{array}{l}\text { SCD significant cold (N. Africa, } \\
\text { N. America, SE. Asia, 2400- } \\
1700 \text { a BC (6) }\end{array}$ \\
\hline 136.31 & $\delta^{18} \mathrm{O}=-19.44 \%$ & $\begin{array}{l}\text { Depleted isotopes-the lowest air } \\
\text { temperatures }\end{array}$ & & \\
\hline 137.251 & $\mathrm{SO}_{4}^{2-}=13.7 ; \mathrm{Ca} / \mathrm{SO}_{4}=2.7$ & 1610 BC \pm 14 er: Santorini, Greece; VEI 7 & & $\begin{array}{l}\text { BI2003: isotopes depletion } \\
\sim 2000 \text { to } 600 \text { a BC }\end{array}$ \\
\hline 138.095 & $\mathrm{SO}_{4}^{2-}=26.6 ; \mathrm{Ca} / \mathrm{SO}_{4}=2.3$ & 1860 BC St. Helens, USA; VEI 6 & & \\
\hline 138.46 & $\mathrm{SO}_{4}^{2-}=30.3 ; \mathrm{Ca} / \mathrm{SO}_{4}=3.0$ & 1900 BC \pm 150 er: Black Peak, Alaska; VEI 6 & & \\
\hline 139.025 & $\mathrm{SO}_{4}^{2-}=22.3 ; \mathrm{Ca} / \mathrm{SO}_{4}=2.9$ & 2040 BC \pm 100 er: Longlsl, N.Guinea;VEI6 & & \\
\hline 141.831 & $\delta^{18} \mathrm{O}=-10.53$ & $\begin{array}{l}\text { Circa } 5100-4600 \text { a BC } \max \delta^{18} \mathrm{O} \text { during } \\
\text { HCO }\end{array}$ & $\begin{array}{l}\text { Holocene Climate } \\
\text { Optimum, HCO }\end{array}$ & $\begin{array}{l}\text { Bl2003: HCO from circa } 6500 \\
\text { to } 3600 \text { a BC }\end{array}$ \\
\hline 141.926 & $\mathrm{SO}_{4}^{2-}=15.0 ; \mathrm{Ca} / \mathrm{SO}_{4}=3.6$ & $\begin{array}{l}4000 \pm 200 \text { BC er: Masaya, Nicaragua; } \\
\text { VEI } 6\end{array}$ & & $\begin{array}{l}\text { Bl2003: enriched on } 10.8 \% \\
\text { from YD }\end{array}$ \\
\hline 142.088 & $\mathrm{SO}_{4}^{2-}=24.7 ; \mathrm{Ca} / \mathrm{SO}_{4}=3.3$ & $5500 \pm 100$ BC er: Mashu, Japan; VEI6; & & \\
\hline 142.65 & $\mathrm{SO}_{4}^{2-}=21.1 ; \mathrm{Ca} / \mathrm{SO}_{4}=5.6$ & $\begin{array}{l}5700 \text { BC er. Kamchatka, Russia; VEI } 6 \text { or } \\
5677 \pm 150 \text { BC er: Crater Lake, Oregon; } \\
\text { VEI } 7\end{array}$ & & \\
\hline $142.8 \pm 0.4$ & $\mathrm{OC}=47.2 \mathrm{ppb} \delta^{18} \mathrm{O}=-14.7$ & $6197 \pm 473$ BC; 8.2 ka cooling episode & & $\begin{array}{l}\text { Cold dry phase }(2,3) \text {. Bl2003: } \\
\text { isotopes depletion }\end{array}$ \\
\hline 143.08 & $\mathrm{SO}_{4}^{2-}=117.8 ; \mathrm{Ca} / \mathrm{SO}_{4}=2.1$ & $6200 \pm 100$ BC er: Kyushu, Japan; VEI6 or & & $\begin{array}{l}\text { CA deserts were forested due to } \\
\text { rainfall, warm temperate }(4,5)\end{array}$ \\
\hline 143.27 & $\delta^{18} \mathrm{O}:$ from -20.3 to -13.39 & 6400 a BC Abrupt warming event (AWE2): & & \\
\hline 143.4 & $\mathrm{SO}_{4}^{2-}=140.9 ; \mathrm{Ca} / \mathrm{SO}_{4}=1.4$ & $6440 \pm 25$ BC er: Kuril L., Kamchatka; VEI7 & & \\
\hline 143.47 & $\delta^{18} \mathrm{O}_{\min }=-20.3$ & \multirow{2}{*}{\multicolumn{2}{|c|}{$\begin{array}{l}\text { 6900-6600 BC Pre Boreal Oscillation event (PBO) } \\
\text { Circa } 7300 \text { a BC Abrupt warming event (AWE1) }\end{array}$}} & Cool PBO \\
\hline 143.82 & $\delta^{18} \mathrm{O}:$ from -21.3 to -16.55 & & & $\begin{array}{l}\text { sharp rise of air temperature in } \\
\text { Europe (1) }\end{array}$ \\
\hline 143.92 & $\mathrm{SO}_{4}^{2-}=140.9 ; \mathrm{Ca} / \mathrm{SO}_{4}=1.4$ & \multirow{2}{*}{\multicolumn{2}{|c|}{$\begin{array}{l}7420 \pm 200 \text { er: Fisher, Aleutian Isl.; VEI } 6 \\
7460 \pm 150 \text { BC er: Pinatubo, Philippines; VEI } 6\end{array}$}} & Bl2003: AWE1 \\
\hline 144.008 & $\mathrm{SO}_{4}^{2-}=192.4 ; \mathrm{Ca} / \mathrm{SO}_{4}=1.3$ & & & \\
\hline & $\mathrm{SO}_{4}^{2-}=50.3 ; \mathrm{Ca} / \mathrm{SO}_{4}=0.7$ & \multicolumn{2}{|l|}{$7480 \pm 80$ BC er: Lvinaya past, Kuril Isl.; VEI $6+$} & $\begin{array}{l}\text { Bl2003: beginning PB; huge } \\
\text { increase of the ions }\end{array}$ \\
\hline 144.04 & $\delta^{18} \mathrm{O}_{\min }=-21.3$ & Circa 7800 BC & Younger Dryas, YD & The most depleted isotopes \\
\hline $145.2 \pm 0.1$ & $\mathrm{OC}=47.2 \mathrm{ppb}$ & $9075 \pm 1221 \mathrm{BC}$ & & \\
\hline 145.236 & $\mathrm{SO}_{4}^{2-}=394.8 ; \mathrm{Ca} / \mathrm{SO}_{4}=1.1$ & $9500 \pm 300$ BC er: Khangar, Kamchatka & & $\begin{array}{l}\text { Massive caldera-forming } \\
\text { eruption }\end{array}$ \\
\hline 145.75 & & Circa10 950 a BC & & $\begin{array}{l}\text { Sharp drop of isotopes; huge } \\
\text { increase of ions }\end{array}$ \\
\hline 145.865 & & & & $\begin{array}{l}\text { BL2003 Bedrock: Altai glaciers } \\
\text { regenerated }\end{array}$ \\
\hline
\end{tabular}

er., eruption; VEI, volcanic explosivity index; ff, forest fire.

1. Johnsen and others (1997); Kobashi and others (2008); 2. Zoller (1960); 3. Alley and others (1997); Alley and Ágústsdóttir (2005); 4. Winkler and Wang (1993); 5. Koshkarova and Koshkarov (2004); 6. Claussen and others (1999); Kalugin and others (2005); 7. Briffa and others (1990); 8. Mann and others (2009); 9. Palais and others (1992); 10. Mayewski and others (1993); Meese and others (1997); Bradley (2000); Bradley and others (2003); 11. Andreev and others (2007); Butvilovskii (1993); Jacoby and others (1996); Ovchinnikov and others (2000); 12. Li and Ku (2002); 13. Stothers (1984); 14. Olivier and others (2006); 15. Vorob'ev and others (2004); 16. Carter and Moghissi (1977); Beck and Bennett (2002); 17. Valendik (1996); Eruptions dates were taken from the Global Volcanism Program (http://www.volcano.si.edu/world/largeeruptions.cfm) and (Zielinski, 1995).

Bl2003 ice core. For different time periods, the slope varied from 8.4 to 6.1. Slopes do not approach typical sublimation/evaporation line slopes $\sim^{\prime} 5^{\prime}$ (Clark and Fritz, 1997) (Table 2). It is unlikely that evaporative/sublimation changes that could occur at site would significantly affect the preserved ice-core records.

\subsection{A steady-state glacier flow model for layer thinning (Figs 7a-c)}

A steady-state glacier flow model was used to determine the ice age, $t$ (a) in the Altai ice core as a function of depth. We applied the numeric modeling of annual ice thickness, $L(z)$ with depth initially presented by Raymond (1983) and implemented by Thompson and others (2000), Yao and Yang (2004), Davis and others (2005) and Kaspari and others (2008), where

$$
L(z)=\operatorname{Ac}(1-z / H)^{k}
$$

and

$$
t=\frac{H^{k}}{[(k-1) \mathrm{Ac}]\left[1 /(H-z)^{k-1}-1 / H^{k-1}\right]}
$$

$H$ (145.867 m w.e.) and $z$ are ice equivalent thickness and depth. Ac (0.344 $\mathrm{m}$ w.e.) is the original layer thickness as determined from the present thickness of annual layers, e.g. 
a
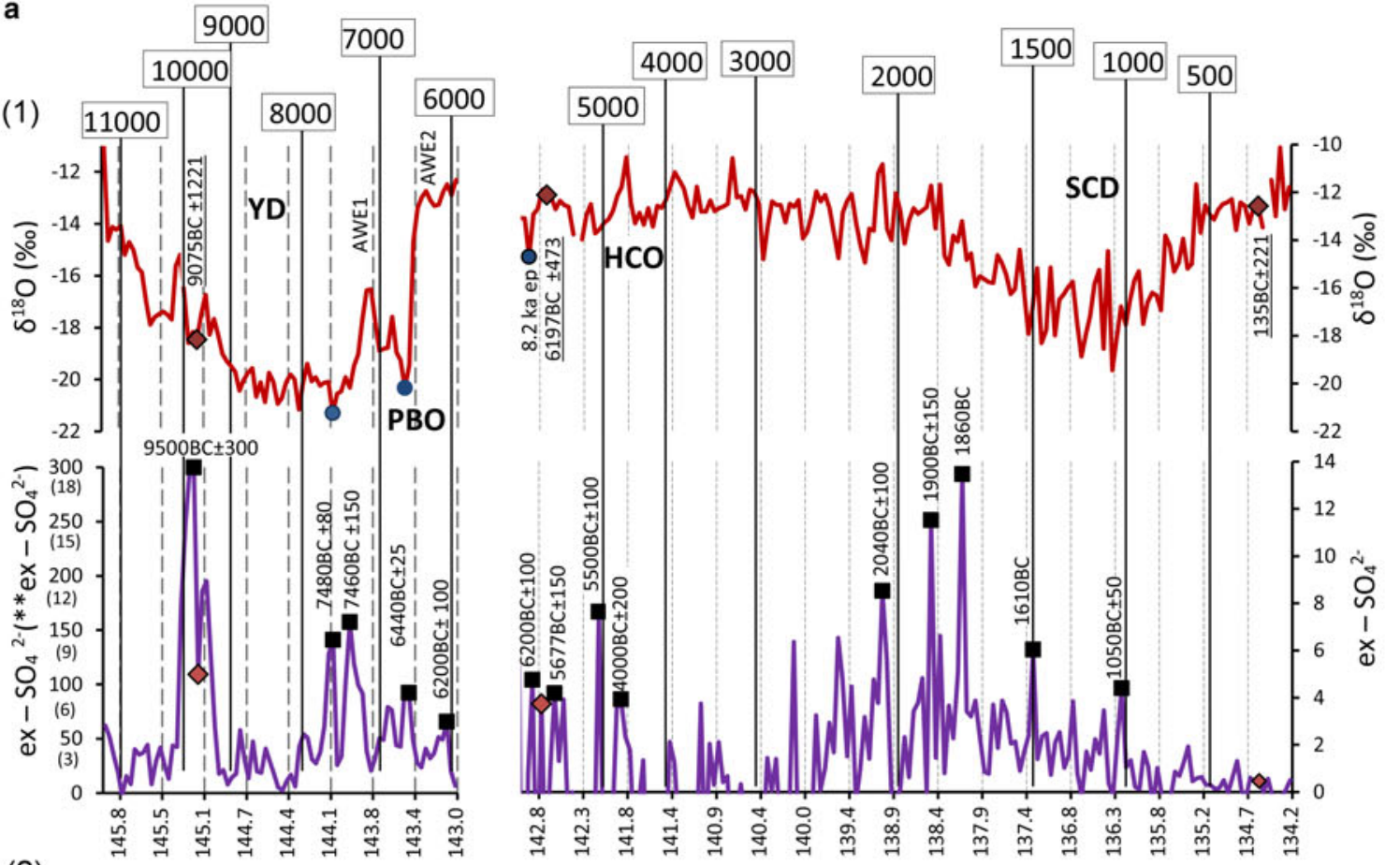

(2)

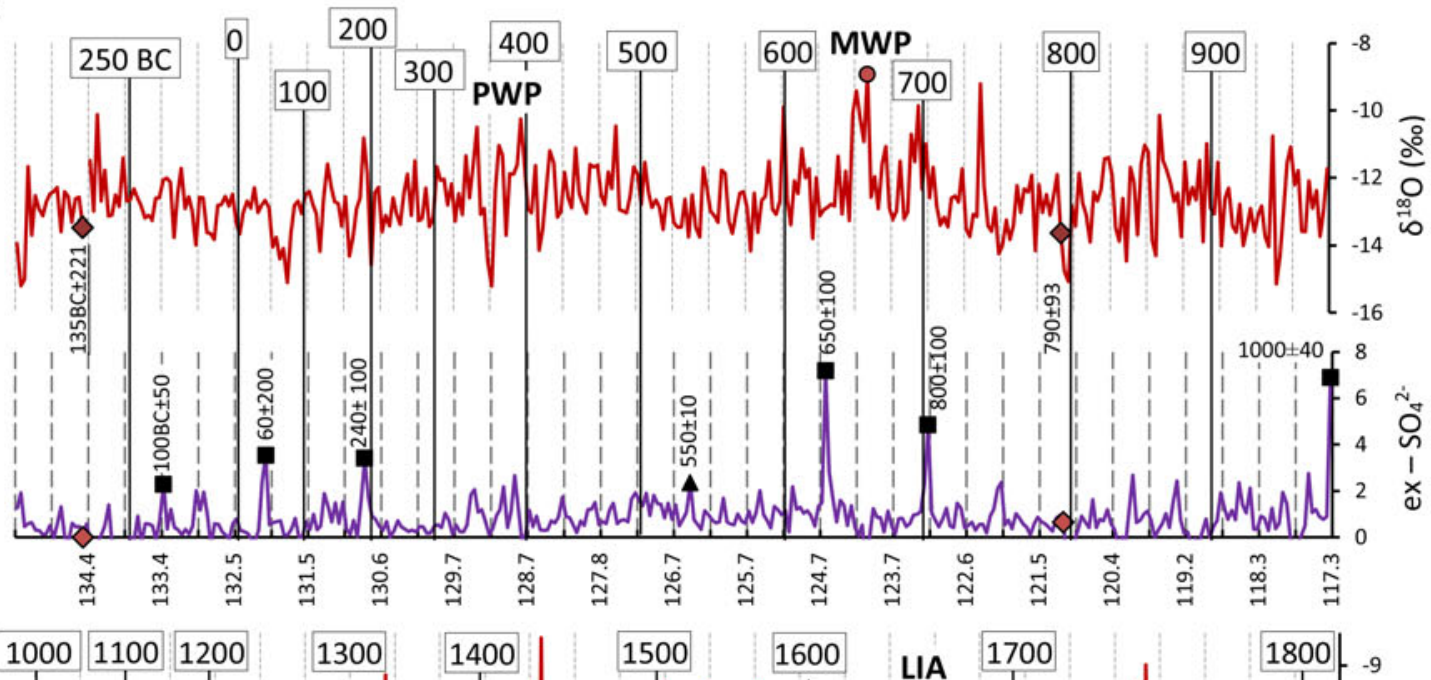

(3)

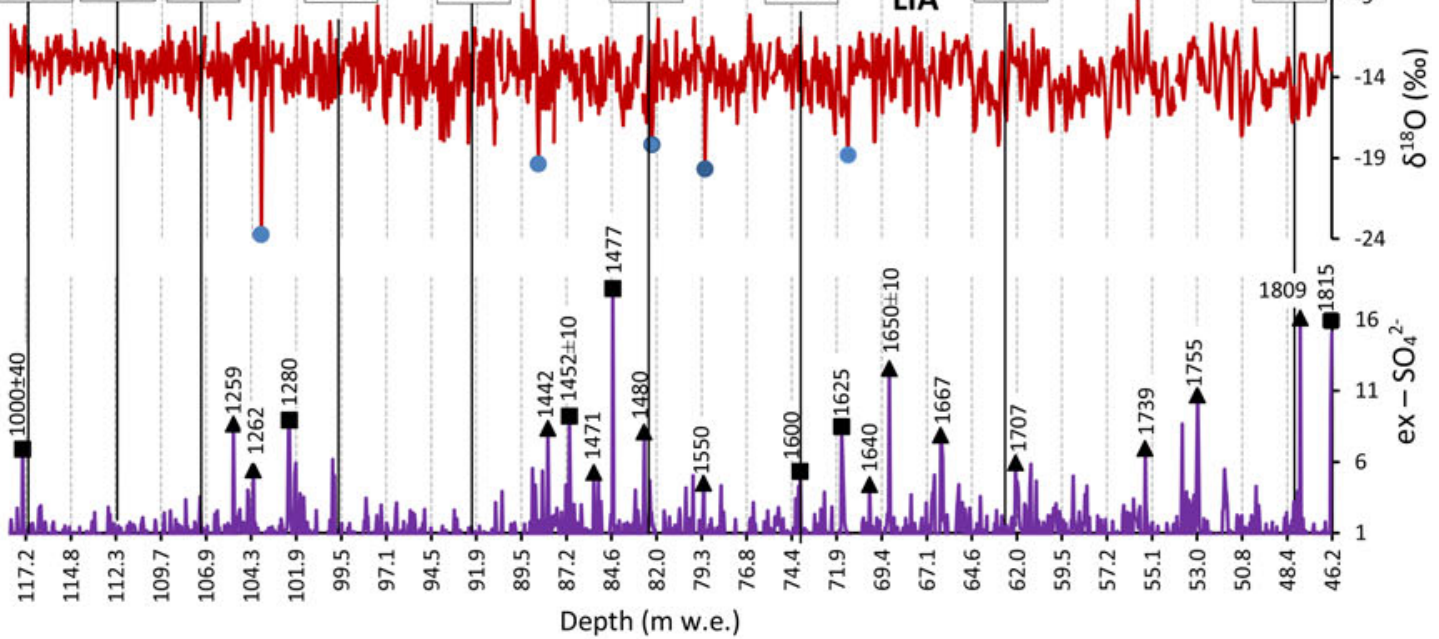

Fig. 5. Ice-core isotope-chemistry records and associated historical events (Table 1) (a) at the low part of the BI2003 ice core: (1) is from 145.8 to 134.2 m w.e., (2) is from 134.5 to 117.3 m w.e., (3) is from 117.3 to $46.2 \mathrm{~m}$ w.e., and (b) at the upper part of the Bl2003 ice core. Stable isotope records of $\delta^{18} \mathrm{O}(\%)$ are red, non-dust sulfate absolute, ex-SO ${ }_{4}^{2-}\left(\mu \mathrm{Eq} \mathrm{L}^{-1}\right)$ and normalized, $* * e x-\mathrm{SO}_{4}^{2-}\left(\mathrm{Eqn}^{(4))}\right.$ and $*$ ex $-\mathrm{SO}_{4}^{2-}(\mathrm{Eqn}$ (5)) fraction records are violet, major ions of $\mathrm{Ca}^{2+}, \mathrm{NO}_{3}^{-}, \mathrm{K}^{+}\left(\mu \mathrm{Eq} \mathrm{L}^{-1}\right)$ are black and radiogenic isotope of ${ }^{3} \mathrm{H}(\mathrm{TU}) ; 1$ is ${ }^{14} \mathrm{C}$ records; $2 \mathrm{l}, 2 \mathrm{~h}$ are extreme low/high temperatures; $3_{5}$ and $3_{\geq 6}$ are referred volcanic eruptions with corresponding $\mathrm{VEI}=5$ and $\mathrm{VEI}=6$ or $7 ; 4$ is Tunguska explosion; 5 is forest fires; 6 is ${ }^{3} \mathrm{H}$ records; 7 is strong dust storm. 


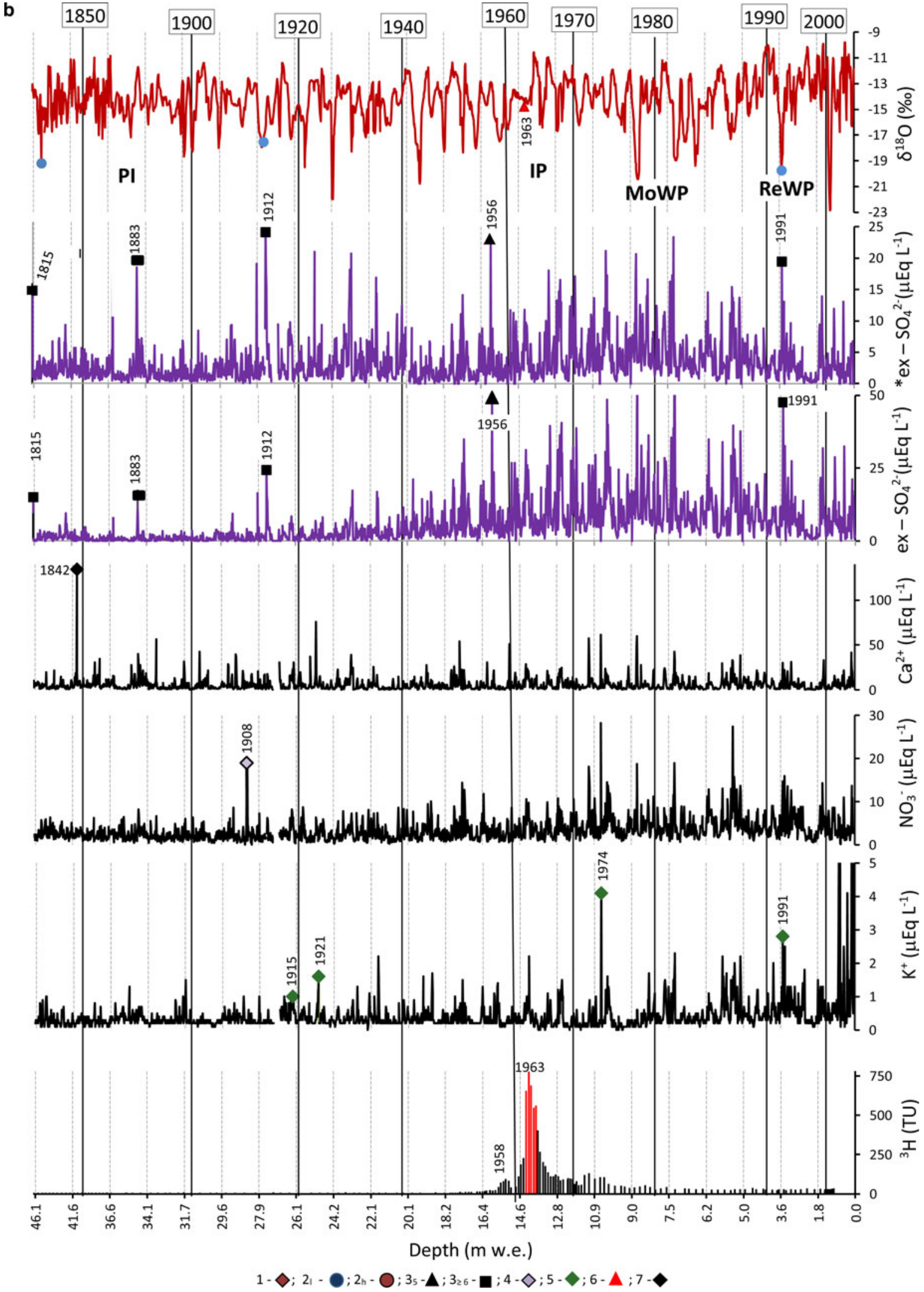

Fig. 5. (continued)

from Eqn (1) the snow pit stratigraphy seasonal layers for 2002, or from Eqn (2) the thickness of snow/firn/ice between two annual timelines, i.e. for the period, 1963 $\left({ }^{3} \mathrm{H}\right.$ marked event; Section 2.1) to the present. $k(1.53)$ is the constant determined by least squares, to minimize the discrepancy in dating.

\subsection{Peaks in sulfate concentrations/volcanic eruptions}

Volcanic eruptions are also used as reference horizons to validate the dating (Zielinski and others, 1994; Zielinski, 1995; Siebert and others, 2010; Moore and others, 2012). For 


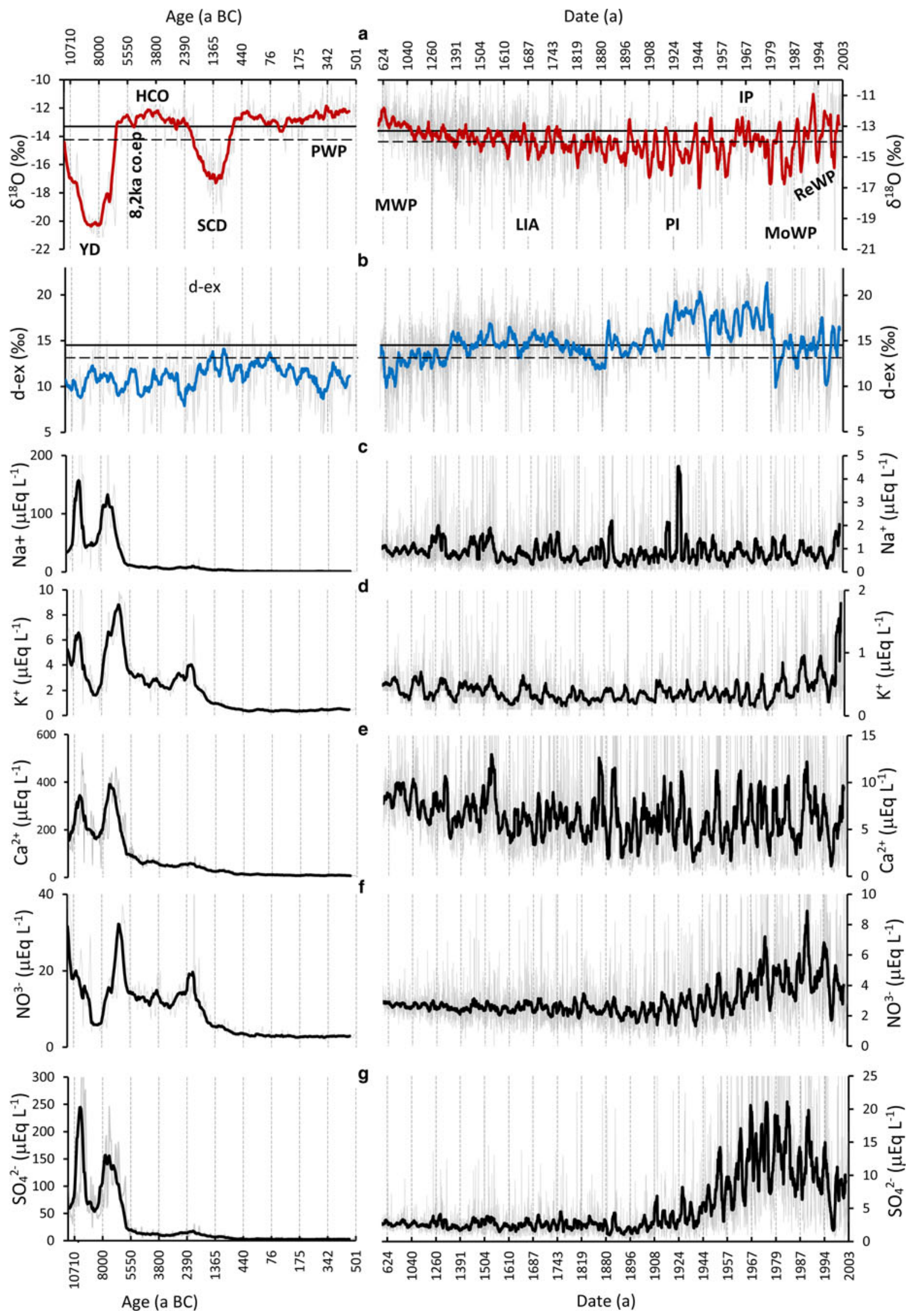

Fig. 6. Dated (a) stable isotope, $\delta^{18} \mathrm{O}\left(\%\right.$ ) , (b) d-ex (\%o) and major ions of (c) $\mathrm{Na}^{+}$, (d) $\mathrm{K}^{+}$, (e) $\mathrm{Ca}^{2+}$, (f) $\mathrm{NO}_{3}^{-}$and (g) $\mathrm{SO}_{4}^{2-}$ records with 10-record and $30-$ record (bold) moving averages and averages for the ReWP (direct solid black) and for the MoWP from (dashed black) from the Bl2003 ice core.

inferring volcanic source analysis, we use the Smithsonian Global Volcanism Program database of Holocene volcanism (Siebert and Simkin, 2002). We considered significant volcanic eruptions with a volcanic explosivity index $(\mathrm{VEI}) \geq 5$ and focused on eruptions that are most likely recorded in Siberian Altai ice-core records, e.g. from Kamchatka, Japan (Table 1). Significant anomalies $(\geq 2 \sigma)$ of sulfate concentrations associated with volcanic eruptions were considered 
Table 2. Mean characteristics of the stable isotope distribution for the different periods of the Altai glacier existence

\begin{tabular}{|c|c|c|c|c|}
\hline & \multirow[b]{2}{*}{ Circa years } & \multicolumn{3}{|c|}{ Mean } \\
\hline & & $\delta^{18} \mathrm{O}$ & d-ex & Slope \\
\hline ReWP & 1993-2003 & -13.3 & 14.4 & 7.6 \\
\hline MoWP & 1973-2003 & -14.1 & 13.9 & 7.7 \\
\hline IP & 1951-1973 & -14.2 & 17.4 & 8.4 \\
\hline PI & 1900-1950 & -14.6 & 16.7 & 8.1 \\
\hline LIA & 1550-1900 AD & -14.2 & 14.4 & 8.0 \\
\hline MWP & $700-1150$ AD & -12.8 & 12.2 & 6.2 \\
\hline SCD & 2000-1000 BC & -16.5 & 12.6 & 6.8 \\
\hline $\mathrm{HCO}$ & $6500-3600 \mathrm{BC}$ & -12.7 & 10.2 & 6.1 \\
\hline $\mathrm{PBO} / \mathrm{YD}$ & 7100/7800-10950 BC & -18.5 & 10.7 & 7.6 \\
\hline
\end{tabular}

as markers for validation of the depth/age scale. However, significant anomalies of sulfate concentrations, $\mathrm{SO}_{4}^{2-}$, may also be associated with $\mathrm{Ca}^{2+}$ (e.g. gypsum and/or anhydrite), which originates from evaporite deposits. If gypsum and/or anhydrite were the primary soluble compound delivering $\mathrm{SO}_{4}^{2-}$ to the site, then a $\mathrm{Ca}^{+2} / \mathrm{SO}_{4}^{2-}$ equivalence ratio $>1$ would be expected. This was not the case for the markers of volcanic eruptions. We considered significant anomalies in sulfate $\left(\mathrm{SO}_{4}^{2-}\right)$ with $\mathrm{Ca}^{2+} / \mathrm{SO}_{4}^{2-}$ equivalence ratios $<1$ above $46.25 \mathrm{~m}$ w.e. (Mt. Tambora eruption in 1815).

Below $46.25 \mathrm{~m}$, e.g. during the LIA and earlier, the $\mathrm{Ca}^{2+}$ background and $\mathrm{Ca}^{2+}$ extremes were more significantly increased than $\mathrm{SO}_{4}^{2-}$. Therefore, to reveal the maxima related to volcanic eruptions we used only the non-dust sulfate fraction (Eqn (3); ex-SO ${ }_{4}^{2-}$ ) (Figs $5 \mathrm{a}$ and b; Table 1) as utilized for the $\mathrm{Bl} 2001$ ice-core dating (Olivier and others, 2006).

$$
\text { ex- } \mathrm{SO}_{4}^{2-}=\mathrm{SO}_{4}^{2-}-n \mathrm{Ca}^{2+}
$$

${ }^{* *} \mathrm{ex}-\mathrm{SO}_{4}^{2-}=\mathrm{SO}_{4}^{2-} / 20-n \mathrm{Ca}^{2-} / 45$ (below $142.8 \mathrm{~m}$ w.e.),

$$
\left.{ }^{*} \text { ex }-\mathrm{SO}_{4}^{2-}=\mathrm{SO}_{4}^{2-} / 2.1-n \mathrm{Ca}^{2-} \text { (above } 17.8 \mathrm{~m} \text { w.e. }\right)
$$

where $n$ is the average ratio between $\mathrm{SO}_{4}^{2-}$ and $\mathrm{Ca}^{2+}$ concentrations for the period, 1815-99 with well-calibrated records of non-volcanic events. The value of $n$ was reported to be 0.21 in the BL2001 ice core (Olivier and others, 2006) and the same value was applied for calculation of the nondust sulfate fraction (ex-SO ${ }_{4}^{2-}$ ) (Eqn (3)) for volcanic eruption indicators in the present study.

For bottom ice-core sections (below $142.8 \mathrm{~m}$ w.e.), $\mathrm{SO}_{4}^{2-}$ and $\mathrm{Ca}^{2+}$ background and extreme concentrations were significantly elevated. Therefore, to compare bottom records with the other part of the ice core, the $\mathrm{SO}_{4}^{2-}$ and $\mathrm{Ca}^{2+}$ bottom records were normalized by an average basic noise factor of ' 20 ' and '45' (Eqn (4)), respectively (Fig. 5a), then the peaks in the non-dust sulfate fraction $\left({ }^{* *} \mathrm{ex}-\mathrm{SO}_{4}^{2-}\right)$ were the same order as those in the other periods, e.g. pre-industrial. Average basic noise was estimated as a ratio between background means during periods of elevated the $\mathrm{SO}_{4}^{2-}$ and $\mathrm{Ca}^{2+}$ concentration (i.e. YD) and background means during the pre-industrial period (PI).

For the upper part of the core (above $17.8 \mathrm{~m}$ w.e.), the $\mathrm{SO}_{4}^{2-}$ background and $\mathrm{SO}_{4}^{2-}$ extreme concentrations were also increased (on average 2.1 times) compared with the lower part of the core (e.g. Pl). A similar procedure of normalization with an average basic noise factor of 2.1 (Eqn (5)) was applied. After normalization peaks in sulfate $\left({ }^{*} \mathrm{ex}-\mathrm{SO}_{4}^{2-}\right)$ were the same order as those for the pre-IP (Fig. 5b).

Intensive growth in sulfate from the background with a simultaneous decline in the $\mathrm{Ca}^{2+} / \mathrm{SO}_{4}^{2-}$ equivalence ratio relative to adjacent records, as well as the non-dust sulfate fraction maxima (Eqns (3-5)), were also considered when assigning volcanic eruptions. The appearance of significantly depleted isotopes follows in many cases after the sulfate anomalies associated with volcanic eruptions (Fig. 5). This illustrates the impact of strong volcanic eruptions on the temporal decrease of air temperatures.

\subsection{Peaks in biomass burning}

The large forested areas of western Siberia and northeastern Kazakhstan are located directly upwind from the Belukha Plateau, and aerosols injected to the atmosphere by large forest fires are preserved in Altai glacier ice. Ice-core records have been used as a proxy for large fire activity by examining the variability of soluble major ions associated with smoke from fire plumes (e.g. Whitlow and others, 1994; Yalcin and others, 2006; Olivier and others, 2006). Eichler and others (2011) demonstrated that $\mathrm{K}^{+}$and $\mathrm{NO}_{3}^{-}$ are suitable proxies for biomass burning and the temporal and spatial distribution of forest fires over Russia, including Siberia, is well known. The largest forest fires in the Altai Mountains and Southwestern Siberia were recorded in 1921, 1974, 1991 and 2003 (Valendik, 1996; Vorob'ev and others, 2004). Peaks in $\mathrm{K}^{+}$potentially associated with forest fires (Fig. 5b; Table 1) were also used to validate dating at the upper part of Bl2003 ice core.

\subsection{Identification of distinct layers: Tunguska meteorite event and a notable dust storm}

The Tunguska explosion event (1908) corresponds to a significant nitrate peak (Henderson and others, 2006) in the B12003 core (at $28.5 \mathrm{~m}$ w.e. depth; Fig. 5b). The most pronounced visible horizon through stratigraphy analysis in the upper part of the $\mathrm{Bl} 2003$ ice cores is a thick dust layer dated to 1842 (Henderson and others, 2006; Malygina, 2009) at $41 \mathrm{~m}$ w.e. signaled by a peak in calcium (Fig. 5b). These two events were also used to calibrate dating in the upper part of the Bl2003 ice core. 


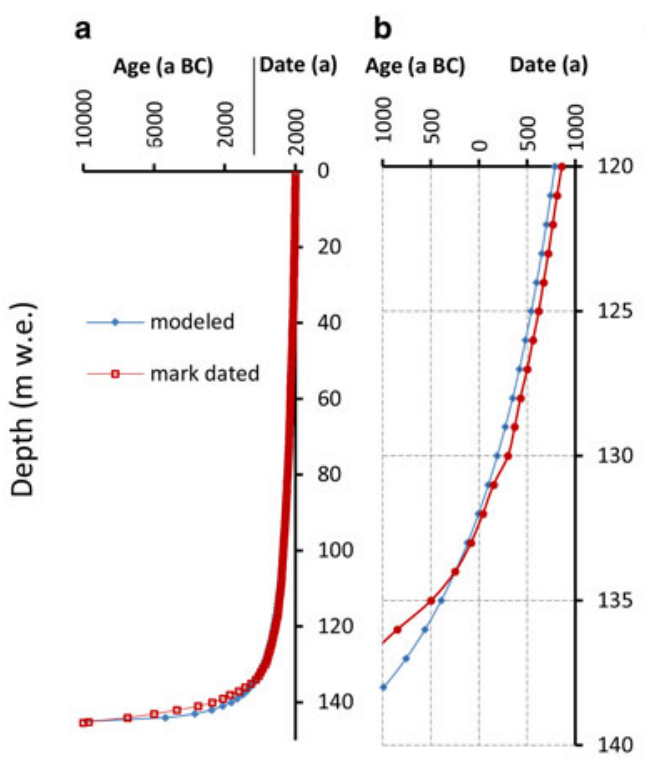

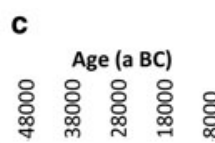

d

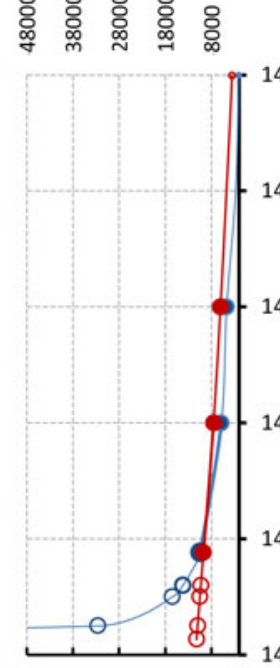

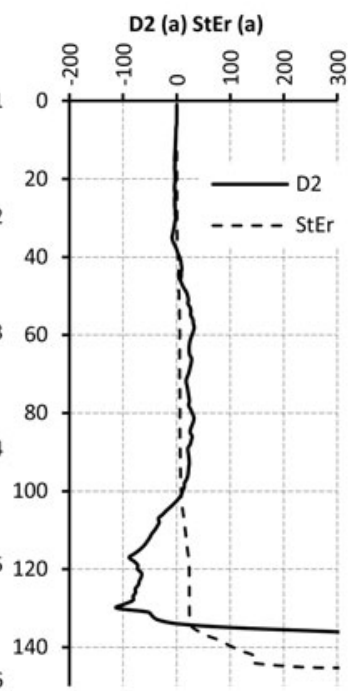

e

D2 (\%)

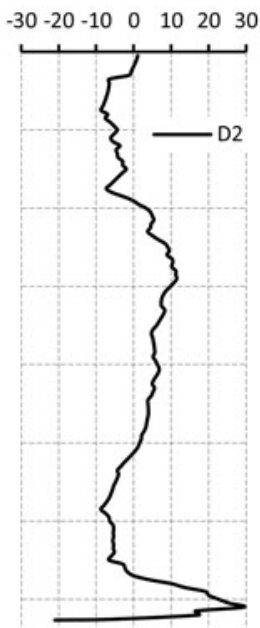

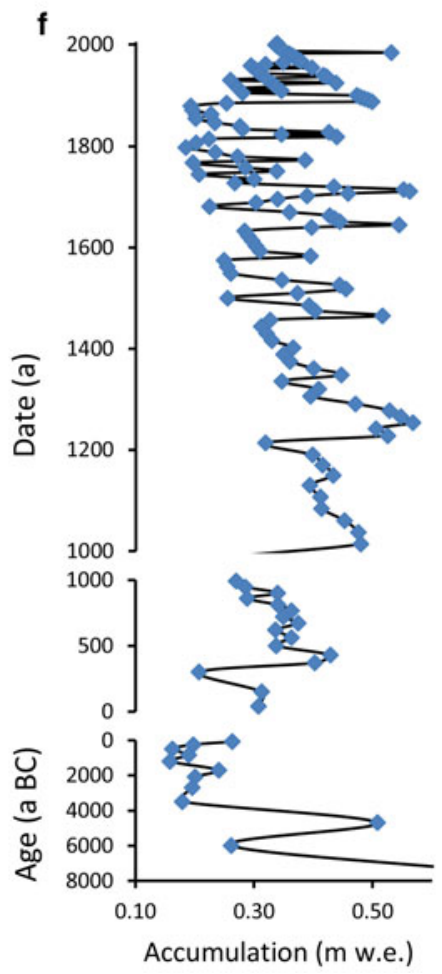

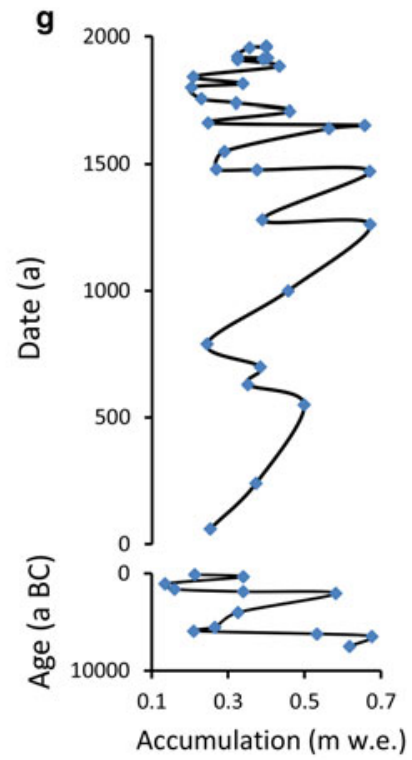

Fig. 7. (a) Modeled and mark-dated age/depth profiles of the Bl2003 ice core with (b) extended bottom part from 120 to $140 \mathrm{~m}$ w.e. and (c) from 141 to $145.87 \mathrm{~m}$ w.e. (d) The standard error profile, StEr (a) and ( $\mathrm{d}$ and e) discrepancy, D2 (a and \%) between modeled and mark-dated Bl2003 ice-core records. Dating validation through annual accumulation estimated for (f) each meter of w.e. and (g) marked events.

\subsection{Discrepancy, uncertainty and standard error}

Discrepancy-1 (D1) over the upper part of the core (until 62 $m$ w.e.) is the difference in years of an horizon dated by different techniques, i.e. tritium picks, stratigraphy/isotope analysis, and validated through volcanic eruption marks (Table 3). Discrepancy-2 (D2), considered along the $\mathrm{Bl} 2003$ ice core (Figs 7d and e), is estimated based on comparison between dated age/depth profile (radioactive measurements, counting annual ice layer through stratigraphy, stable isotopes, etc.) and the calculated profile using a steady-state glacier flow model for layer thinning (Section 3.5) with validation through volcanic eruption events. The absolute discrepancy (Fig. 7d) is estimated as the absolute difference in years of a horizon. Relative discrepancy is the ratio between the difference in dated years (D2) and the number of years from the surface (Table 3 ).

Uncertainty-1 (U1), below $121.1 \mathrm{~m}$ w.e. is based on the uncertainty of validation referenced by volcanic eruption dating (Siebert and Simkin, 2002). Uncertainty-2 (U2) is the uncertainty in ${ }^{14} \mathrm{C}$ measurements of the four POC horizons and values of uncertainty interpolated between the four ${ }^{14} \mathrm{C}$ measured horizons. Absolute and relative values of uncertainty are estimated in years and percent relative to mean year of a horizon (Table 3).

The standard error, StEr (a) of dated Bl2003 ice-core records relative to modeled results is estimated beginning in 1963 (for the period 1963-2003) and earlier (deeper) (Table 3; Fig. 7d). Determination of the 1963 tritium peak 
Table 3. Measured and modeled age, and discrepancy (D1, D2), uncertainty (U1, U2) and standard errors (StEr) in dating of the Bl2003 ice core

\begin{tabular}{|c|c|c|c|c|c|c|c|c|c|c|c|c|}
\hline $\begin{array}{l}\text { Depth } \\
\text { m w.e. }\end{array}$ & Event & Measured and validated age determinant & $\begin{array}{l}\text { Measured } \\
\text { Date }\end{array}$ & $\begin{array}{c}\text { D1 } \\
\mathrm{a}\end{array}$ & $\begin{array}{l}\text { Modeled } \\
\text { age }\end{array}$ & $\begin{array}{c}\mathrm{D} 2 \\
\mathrm{a}\end{array}$ & $\%$ & $\begin{array}{l}\text { Age } \\
\text { Bl2003 }\end{array}$ & $\begin{array}{l}\text { U1 } \\
\mathrm{a}\end{array}$ & $\begin{array}{c}\mathrm{U} 2 \\
\mathrm{a}\end{array}$ & $\begin{array}{l}\cup 2 \\
\%\end{array}$ & $\begin{array}{c}\text { StEr } \\
\text { a }\end{array}$ \\
\hline 3.4 & Pinatubo er. & $\begin{array}{l}\mathrm{Ca} / \mathrm{SO}_{4} ; \mathrm{ex}-\mathrm{SO}_{4}^{2-} \\
\text { Stratigr } / \delta^{18} \mathrm{O}\end{array}$ & $\begin{array}{l}1991 \\
1991\end{array}$ & & 1990.9 & 0 & -1 & 1991 & & & & \\
\hline 14.1 & Max nuclear detonations & $\begin{array}{l}{ }^{3} \mathrm{H} \\
\text { Stratigr/ } \delta^{18} \mathrm{O}\end{array}$ & $\begin{array}{l}1963 \\
1964\end{array}$ & 1 & 1961.5 & -1.5 & -3.7 & 1963 & & & & 0.5 \\
\hline 15.2 & First nuclear detonations & $\begin{array}{l}\delta^{3} \mathrm{H} \\
\text { Stratigr } / \delta^{18} \mathrm{O}\end{array}$ & $\begin{array}{l}1958 \\
1960\end{array}$ & 2 & 1954 & -4 & -7 & 1958 & & & & 0.7 \\
\hline 27.56 & Novarupta er. & $\begin{array}{l}\mathrm{Ca} / \mathrm{SO}_{4} ; \mathrm{ex}-\mathrm{SO}_{4}^{2-} \\
\text { Stratigr } / \delta^{18} \mathrm{O}\end{array}$ & $\begin{array}{l}1912 \\
1916\end{array}$ & 4 & 1908 & -4 & -3.9 & 1912 & & & & 1.2 \\
\hline 28.5 & Tunguska event & $\begin{array}{l}\mathrm{NO}_{3} \\
\text { Stratigr/ } \delta^{18} \mathrm{O}\end{array}$ & $\begin{array}{l}1908 \\
1912\end{array}$ & 4 & 1905 & -3 & -3 & 1908 & & & & 1.3 \\
\hline 35.96 & Krakatoa er. & $\begin{array}{l}\mathrm{Ca} / \mathrm{SO}_{4} ; \mathrm{ex}-\mathrm{SO}_{4}^{2-} \\
\text { Stratigr } / \delta^{18} \mathrm{O}\end{array}$ & $\begin{array}{l}1883 \\
1889\end{array}$ & 6 & 1874 & -9 & -8 & 1883 & & & & 1.6 \\
\hline 41 & Dust storm & $\begin{array}{l}\mathrm{Ca}^{2+} \\
\text { Stratigr } / \delta^{18} \mathrm{O}\end{array}$ & $\begin{array}{l}1842 \\
1847\end{array}$ & 5 & 1850 & 8 & 6 & 1842 & & & & 2.5 \\
\hline 46.25 & Tambora er. & $\begin{array}{l}\mathrm{Ca} / \mathrm{SO}_{4} ; \mathrm{ex}-\mathrm{SO}_{4}^{2-} \\
\text { Stratigr } / \delta^{18} \mathrm{O}\end{array}$ & $\begin{array}{l}1815 \\
1824\end{array}$ & 9 & 1822 & 7 & 7 & 1815 & & & & 2.9 \\
\hline 47.74 & Unknown er. & $\begin{array}{l}\mathrm{Ca} / \mathrm{SO}_{4} ; \mathrm{ex}-\mathrm{SO}_{4}^{2-} \\
\text { Stratigr } / \delta^{18} \mathrm{O}\end{array}$ & $\begin{array}{l}1809 \\
1805\end{array}$ & 12 & 1814 & 15 & 8 & 1809 & & & & 3.7 \\
\hline 62.1 & Fuji er. & $\begin{array}{l}\text { ex-SO } \\
\text { Stratigr }\end{array}$ & $\begin{array}{l}1707 \\
1723\end{array}$ & 16 & 1730 & 23 & 8 & 1707 & & & & 6.2 \\
\hline 66.37 & Usu/Shikotsu ers. & $\mathrm{ex}-\mathrm{SO}_{4}^{2-}$ & 1665 & & 1691 & 24 & 8 & 1667 & & & & 6.1 \\
\hline 71.59 & Huaynaputina er. & ex- $\mathrm{SO}_{4}^{2-}$ & 1610 & & 1633 & 23 & 9 & 1610 & & & & 6.4 \\
\hline 84.5 & Bardarbunga er. & ex- $-\mathrm{SO}_{4}^{2-2}$ & 1477 & & 1515 & 35 & 7 & 1480 & & & & 7.1 \\
\hline 102.3 & Quiloto er. & ex- $\mathrm{SO}_{4}^{2-}$ & 1271 & & 1283 & 3 & 0 & 1280 & & & & 9.9 \\
\hline 104.16 & El Chichon & ex-SO ${ }_{4}^{2-}$ & 1255 & & 1248 & -11 & -1 & 1259 & & & & 11.2 \\
\hline 117.3 & Changbaishan er. & ex-SO ${ }_{4}^{2-}$ & 1000 & & 921 & -79 & -9 & 1000 & & & & 22.7 \\
\hline $121.1 \pm 0.37$ & & OC ppb & $790 \pm 93$ & & 744 & -66 & -6 & 810 & & 186 & 15 & 24.0 \\
\hline 123.2 & Churchill er. & ex-SO ${ }_{4}^{2-}$ & $800 \pm 100$ & & 650 & -70 & -5 & 720 & 200 & 227 & & 24.1 \\
\hline 124.57 & Opala er. & ex- $\mathrm{SO}_{4}^{2-}$ & $610 \pm 50$ & & 565 & -75 & -5 & 640 & 100 & 253 & & 24.1 \\
\hline 130.75 & Ksudach er. & ex- $\mathrm{SO}_{4}^{2-}$ & $240 \pm 100$ & & $156 \mathrm{AD}$ & -84 & -4 & 240 & 200 & 370 & & 24.3 \\
\hline 132.05 & Churchill er. & ex-SO ${ }_{4}^{2-}$ & $60 \mathrm{AD} \pm 200$ & & $6 \mathrm{BC}$ & -46 & -2 & $40 \mathrm{AD}$ & 400 & 394 & & 24.5 \\
\hline 132.88 & Okmok er. & ex- $\mathrm{SO}_{4}^{2-}$ & $100 \mathrm{BC} \pm 50$ & & $115 \mathrm{BC}$ & -35 & -2 & $80 \mathrm{BC}$ & 100 & 410 & & 24.8 \\
\hline $134.6 \pm 0.39$ & & OC & $135 \mathrm{BC} \pm 221$ & & $326 \mathrm{BC}$ & 4 & 0 & $330 \mathrm{BC}$ & & 442 & 20 & 26.0 \\
\hline 136.187 & Pinatubo er, & ex-SO ${ }_{4}^{2-}$ & $1050 \mathrm{BC} \pm 500$ & & $570 \mathrm{BC}$ & 330 & 12 & $900 \mathrm{BC}$ & 1000 & 540 & & 48.3 \\
\hline 137.251 & Santorini er. & ex-SO ${ }_{4}^{2-}$ & $1610 \mathrm{BC} \pm 14$ & & $850 \mathrm{BC}$ & 740 & 19 & $1590 \mathrm{BC}$ & 28 & 605 & & 67.0 \\
\hline 138.095 & St.Helens er. & ex- $\mathrm{SO}_{4}^{2-}$ & $1860 \mathrm{BC}$ & & $1020 \mathrm{BC}$ & 840 & 18 & $1860 \mathrm{BC}$ & & 657 & & 76.6 \\
\hline 139.025 & Long IsI er. & $\mathrm{ex}-\mathrm{SO}_{4}^{2-}$ & $2040 \mathrm{BC} \pm 100$ & & $1310 \mathrm{BC}$ & 790 & 19 & $2100 \mathrm{BC}$ & 200 & 714 & & 91 \\
\hline $142.8 \pm 0.42$ & & OC & $6297 \mathrm{BC} \pm 473$ & & $4685 \mathrm{BC}$ & 1315 & 16 & $6000 \mathrm{BC}$ & & 946 & 11 & \\
\hline
\end{tabular}




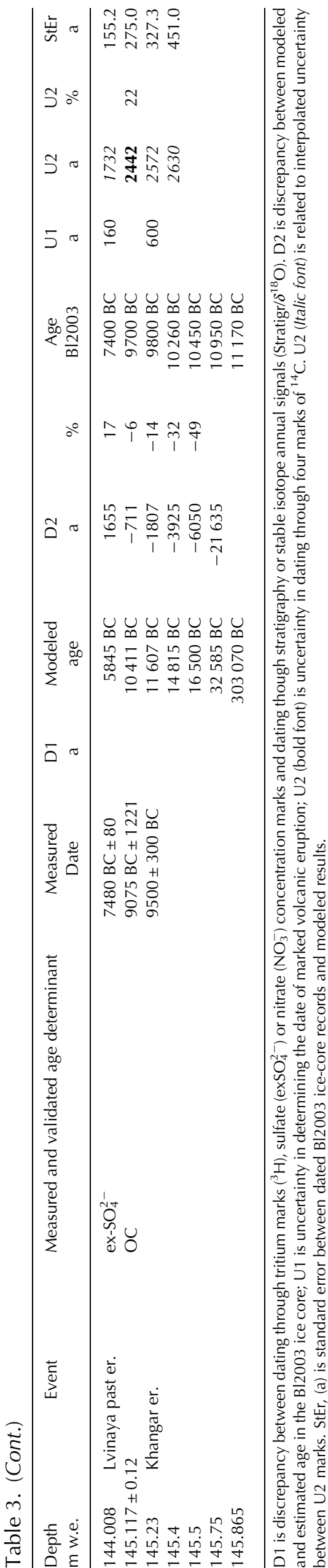

through the seasonal signal in isotope/stratigraphy analysis yields a discrepancy of 1 year. Comparison of modeled depth/age with 1963 radioactive markers yields a discrepancy (D2) within 1.5 years, i.e. $\sim 3.7 \%$ of the 40 years period from 1963 to 2003. StEr of dated Bl2003 ice-core records relative to modeled (Eqn (2)) is estimated as 0.5 year from 1963 to 2003 (Table 3).

Discrepancy (D1) is 4 years at the depth of the local sulfate peak (27.56 m w.e.) as attributed to the 1912 Novarupta eruption (Table 3). Validation of modeled dating through dating by ex- $\mathrm{SO}_{4}^{2-}$, yields a discrepancy within 4 years, i.e. $\sim 4 \%$, at the 1912 horizon. Depth $117.3 \mathrm{~m}$ w.e., modeled to $1000 \mathrm{AD}$ is validated through the Changbaishan eruption, yielding a discrepancy of $9 \%$ between modeled dating and validation through ex- $\mathrm{SO}_{4}^{2-}$.

The discrepancy between dated ice-core and modeled profiles is $<10 \%$ above $135 \mathrm{~m}$ w.e. (till $~ 330$ a BC) in the Bl2003 ice core (Table 3; Fig. 7e). Standard error between dated and modeled ice-core records at $135 \mathrm{~m}$ w.e. is 26 years.

Below $135 \mathrm{~m}$ w.e. the discrepancy increased, reaching a maximum at the bottom. Until $145.4 \mathrm{~m}$ w.e. ( 10 900 BC) the discrepancy (D2) in dated ice-core records is within the values of uncertainty $(\cup 2)$ of ${ }^{14} \mathrm{C}$ measurement (Table 3 ). The discrepancy does not exceed $6 \%$ at three radiocarbon marked horizons. The discrepancy in dating through radiocarbon marks and modeled dating could be explained by a deviation in accumulation rate (Fig. $7 f$ and $g$ ) from modeled accumulation ( $0.344 \mathrm{~m}$ w.e.) during periods of variable Altai accumulation rate history.

\section{ISOTOPE/AIR TEMPERATURE RELATIONSHIPS}

The variability of the stable isotope records from ice cores is used to estimate isotope/air temperature relationships. We examined isotope data from 136 precipitation events collected year-round at the Akkem meteorological station with corresponding mean air temperature during precipitation events. Eighty one events occurring during negative temperature periods at the Akkem station were selected.

The first step: The relationship between mean air temperatures during precipitation $\left(\mathrm{T}_{\mathrm{pr}}\right)$ and $\delta^{18} \mathrm{O}$ at Akkem station, $T_{\text {pr. }}=0.9 \delta^{18} \mathrm{O}+12.1$, was adjusted using the transfer function:

$$
T_{\text {pr. }}=0.9( \pm 0.08) \delta^{18} \mathrm{O}+3.2 R^{2}=0.7(\text { at } \alpha=0.05)
$$

with air temperature lapse rate, $-0.43^{\circ} \mathrm{C}\left(100 \mathrm{~m}^{-1}\right)$. We assume the isotopic composition of the precipitation deposited at the Akkem station is equivalent to the isotopic composition of the precipitation deposited at the Belukha Plateau. The air temperature lapse rate was obtained based on air temperatures measurements at AWS and Akkem station during the precipitation events. The standard error in air temperature during precipitation events modeled through stable isotope ratio in precipitation is estimated at $2.7^{\circ} \mathrm{C}$.

The second step: The Siberian Altai is located at the center of the Eurasian continent (Fig. 1) under the strong influence of the Siberian High $(\mathrm{SH})$ and westerly jet stream. In winter, the $\mathrm{SH}$ blocks advection of fresh water transport, while in the warm season when the $\mathrm{SH}$ is weak maximum precipitation occurs throughout the Altai glacier region (Köppen climate classification). Currently, $86 \%$ of the annual precipitation in the Altai Mountains occurs during the warm season from May to October (Aizen and others, 2005). The warm season is clearly when maximum precipitation occurs, due to the 

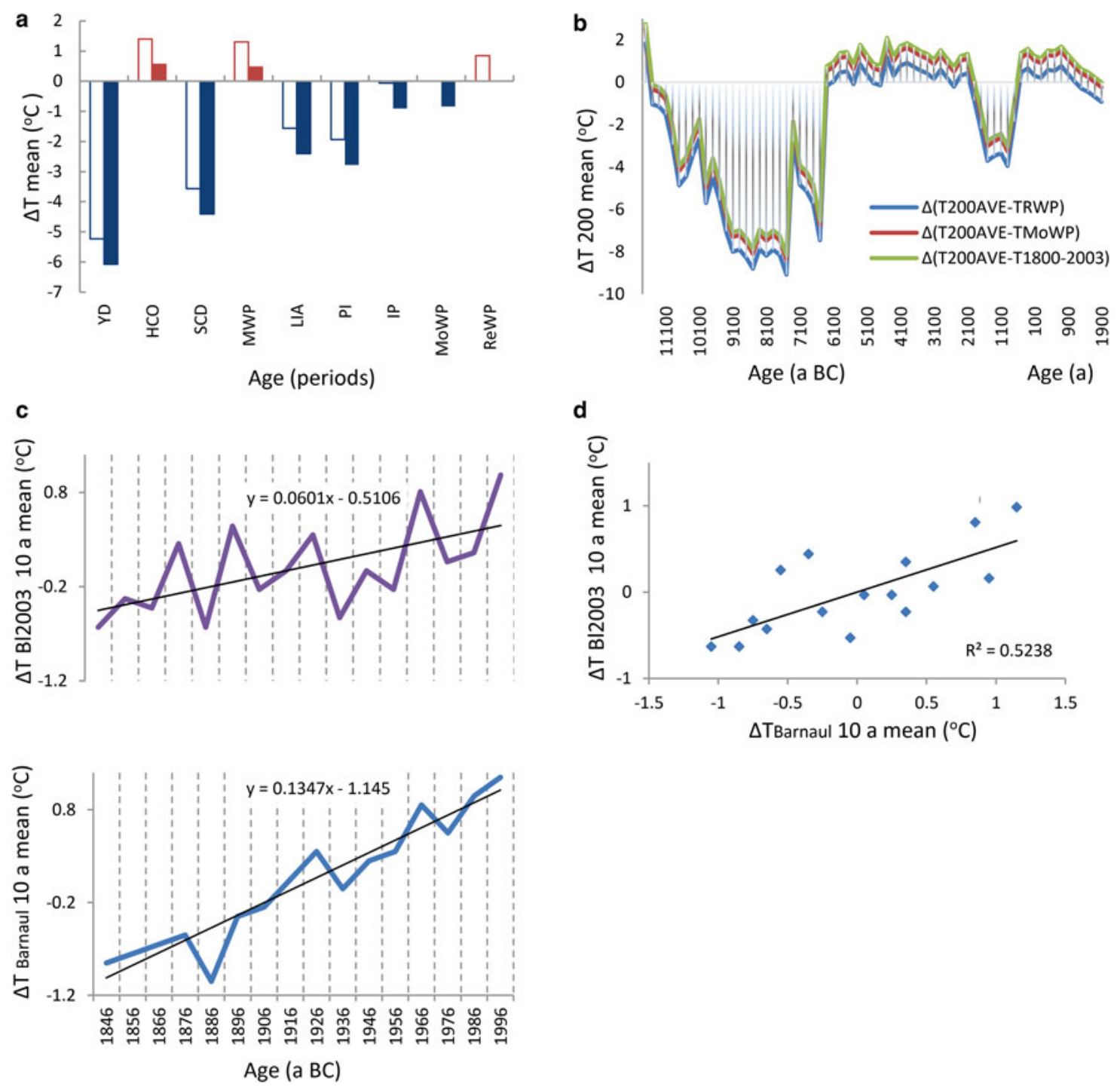

Fig. 8. (a) Average estimations on reconstructed air temperature deviations, $\Delta T,\left({ }^{\circ} \mathrm{C}\right)$ from the Recent (filled column: red is for positive and blue is for negative deviations) and Modern (not filled) Warm Periods for the different historical periods. (b) Bicentennial deviations of reconstructed air temperature from the Recent (green) and Modern (red) Warm Period mean of air temperatures and the last bicentennial mean (blue). (c) Decadal mean deviations from the last decadal mean of air temperature reconstructed from Bl2003 ice-core records and from Barnaul Station. (d) Correlation between deviations from the last decadal mean of decadal air temperature means at the Barnaul Station and reconstructed from the Bl2003 ice-core records.

'blocking' effect of the $\mathrm{SH}$, which decreases precipitation during the cold seasons. Therefore, stable isotopes in ice-core records are biased toward warm season air temperatures, i.e. air temperature during precipitation events. The information recorded in Bl2003 ice core during the cold season is limited.

To take into account air temperatures without precipitation, a relationship between annual air temperature during precipitation $\left(T_{\mathrm{pr}}\right)$ and mean annual air temperature ( $\left.T_{\text {reconstr }}\right)($ Eqn (7)) was developed based on long-term data from Akkem station for the period, 1951-2001:

$$
\begin{aligned}
T_{\text {reconstr }} & =-0.055\left(T_{\mathrm{pr}}\right)^{2}+0.012 T_{\mathrm{pr}}-11.234 \\
R^{2} & =0.52,
\end{aligned}
$$

where $T_{\mathrm{pr}}$ is calculated as the mean annual precipitationweighted temperature, $\sum k T, k$ is the share of monthly amount of precipitation in the annual total and $T$ is the mean monthly temperature. The standard error of mean annual air temperature, reconstructed from the mean annual air temperature during precipitation, is estimated at $0.68{ }^{\circ} \mathrm{C}$.
Validation of the estimations in reconstructed air temperature deviations was achieved using the deviations of the decadal annual mean air temperatures from the average for the period, 1841-2001 from the Barnaul station. The decadal air temperature deviation variability at Barnaul station is similar to the variability in reconstructed decadal means of air temperature deviations from Bl2003 ice-core records (Fig. 8c) and the correlation is 0.52 for 16 decadal means (Fig. 8d). The tendency of increased/decreased air temperatures in the $\mathrm{Bl} 2003$ ice-core records is in accordance with Barnaul station data, while the amplitude of variability in air temperature deviations at the Barnaul station is insignificantly lower than in ice-core records. The long-term trend in air temperature deviations is more intense at the Barnaul station $\left(0.13{ }^{\circ} \mathrm{C}\left(10 \mathrm{yrs}^{-1}\right)\right)$ than revealed from Bl2003 ice-core records $\left(0.06^{\circ} \mathrm{C}\left(10 \mathrm{yrs}^{-1}\right)\right)$.

\section{ISOTOPE/d-ex RELATIONSHIP}

Analysis of the main synoptic patterns that deliver moisture to the Altai Mountains reveals several clusters of moisture origin 
(Aizen and others, 2005, 2006), e.g. moisture originating over the Atlantic Ocean formed accumulation with d-ex values ranging from 7 to $14 \%$ and intermediate $d$-ex values of $10 \%$. Accumulation with $\mathrm{d}$-ex records $<7 \%$ is formed by moisture originating from the Pacific Ocean or the Northern Atlantic Ocean depending on $\delta^{18} \mathrm{O}$. That is, moisture enriched in $\delta^{18} \mathrm{O}$ is generally derived from the Pacific Ocean, while moisture depleted in $\delta^{18} \mathrm{O}$ is generally derived from the northern Atlantic or Arctic Oceans. The dex values over $14 \%$ are typical of re-evaporated moisture from southwestern regions, e.g. Caspian, Aral and Black seas (Froehlich and others, 2002; Aizen and others, 2005, 2006).

\section{NET ACCUMULATION}

Snow/firn/ice densities (Fig. 2) and annual layer modeled thinning coefficients were used to establish cumulative and w.e. depth profiles. The visual stratigraphy, depths of peaks in tritium concentration and $\delta^{18} \mathrm{O}$ analysis validated through multiple sulfate peaks, forest fires, the Tunguska explosion event, and a dust storm in 1842 reveal an average annual net accumulation of $\sim 0.34$ at $46.25 \mathrm{~m}$ w.e. coincident with the depth of the Tambora eruption in 1815; 0.36 at $28.5 \mathrm{~m}$ w.e. coincident with the 1908 Tunguska explosion event, and $\sim 0.35 \mathrm{~m}$ w.e. in the upper $14.1 \mathrm{~m}$ w.e. coincident with the 1963 nuclear detonation.

To verify the credibility of the developed time scale (Table 1) a profile of annual accumulation rate from surface to $145 \mathrm{~m}$ w.e. was estimated for $1 \mathrm{~m}$ w.e. resolution (Fig. $7 \mathrm{f}$ ) and for the main time-marked events (Table 1; Fig. 7g) using the modeled thinning coefficients. The last section of $0.865 \mathrm{~m}$ w.e. from the bedrock was excluded due to the nonlinear increase of modeled thinning coefficients.

Estimated annual accumulation rate varied on average from $0.16 \mathrm{~m}$ w.e. during cold periods, up to $0.70 \mathrm{~m}$ w.e. during warm periods of Altai's glaciation history (Figs $7 f$ and g), demonstrating the credibility of the developed icecore time scale.

\section{RESULTS}

\subsection{Ice-core depth/age scale and historical events}

\subsubsection{Younger Dryas}

7.1.1.1. Intense depletion in $\delta^{18} \mathrm{O}$. It was observed in more than 100 ice-core samples $(0.02-0.03 \mathrm{~m}$ w.e. resolution) at the bottom of the core, close to the bedrock (Figs 4 and 6 a). The depletion in $\delta^{18} \mathrm{O}$ from -10.8 to $-21.3 \%$ indicates an extreme decrease in air temperature.

Taking into account the ${ }^{14} \mathrm{C}$ measurement at $145.117 \pm$ $0.12 \mathrm{~m}$ w.e. depth dating to $9075 \pm 1221 \mathrm{cal}$ a BC (Fig. 5a (1); Section 3.2), modeled depth dating to 10411 a BC (Table 3) and validated dating through the highest maxima in non-dust sulfate fraction at $145.23 \mathrm{~m}$ w.e. depth, associated with the massive caldera-forming Khangar, Kamchatka eruption dated to $9500 \pm 300$ a BC (Siebert and Simkin, 2002) (Table 1), we assigned the $145.117 \pm$ $0.12 \mathrm{~m}$ w.e. depth to $9700 \mathrm{cal} \mathrm{a}$ BC and the $145.23 \mathrm{~m}$ depth to $9800 \mathrm{cal}$ a BC using the possible range of uncertainties in dating for both the ${ }^{14} \mathrm{C}$ estimation and the Khangar eruption (Table 3). Dating of these two horizons is in accordance with model-based dating, i.e. the discrepancy is within the uncertainty of measurements. The rest of the $0.64 \mathrm{~m}$ w.e. to the bottom is related to the beginning of a significant drop in isotopes (Figs $5 \mathrm{a}(1)$ and $4 \mathrm{a}$ ). We suggest this indicates the beginning of the YD in the Siberian Altai. The linear extrapolation to the bottom from $145.23 \mathrm{~m}$ locates the beginning of the YD at $10950 \mathrm{cal}$ a $B C$ at $145.75 \mathrm{~m}$ w.e., approximately coinciding with the beginning of the GISP-2 YD event (Fig. 9a) (Peteet, 1995; Alley and others, 2000; Rasmussen and others, 2006; Lowe and others, 2008; Steffensen and others, 2008). The flow model (Fig. 7c, Table 3) suggests accelerated and unrealistic thinning of layers deeper than $145.23 \mathrm{~m}$ w.e., i.e. $32585 \mathrm{cal}$ a BC at $145.75 \mathrm{~m}$ w.e. and the basal ice at the bedrock of $145.865 \mathrm{~m}$ w.e. depth is dated at 303070 years BC according to the model.

We suggest that the Altai's glaciers were re-generated during the YD. This is in accordance with radiocarbon measurements of organic soil from the bottom of a $87.46 \mathrm{~m}$ surface to bedrock ice core from the inner Tien Shan (Grigor'eva ice cap, Gr2007; $42^{\circ} \mathrm{N}, 78^{\circ} \mathrm{E} ; 4563 \mathrm{~m}$ a.s.l.), about $1500 \mathrm{~km}$ southwest of the Altai. The radiocarbon measurements revealed that the present Tien Shan ice cap contains no ice that formed in the last glacial maximum (Fig. 9a) (Takeuchi and others, 2014).

The YD was identified in Northern Europe as a cooling event experienced throughout the entire North Atlantic Region. The end of the YD, based mainly on the GISP2 ice core, is 9640 a BC (Fig. 9a; Alley and others, 2000). In arid Northeast Asia, the YD was an exceptionally cool, dry climate dated between 10900 and 9600 cal a BC (Herzschuh, 2006). However, this was not universally the case; ambiguities exist in the paleo-environmental record of the region, e.g. some lake basins along the eastern face of the Altai Mountains began to recover $\sim 8000 \mathrm{cal}$ a BC, and permafrost layers of Gobi Desert soils degraded $\sim 8000$ cal a BC as temperatures increased (Rhodes and others, 1996; Yang and others, 2004; Okishev, 2011).

Our results do not prove that the YD was synchronously recorded in the Altai and in Greenland. The deepest ${ }^{14} \mathrm{C}$ measured horizon at $145.2 \mathrm{~m}$ w.e. depth in the Bl2003 ice core corresponds to $9075 \pm 1221 \mathrm{cal} \mathrm{a} \mathrm{BC}$ and assigned to $9700 \mathrm{cal}$ a BC is located at the beginning of intensive depletion in $\delta^{18} \mathrm{O}$, while the same spot with age of $9700 \mathrm{cal}$ a BC in the Guliya ice core (Thompson and others, 1997) and in the GISP2 (Alley and others, 2000) ice core corresponds respectively to the middle and to the end of isotope depletion (Fig. 9a). The second from the bottom ${ }^{14} \mathrm{C}$ measured horizon at $142.82 \mathrm{~m}$ w.e. corresponding to $6197 \pm 473 \mathrm{cal}$ a BC and assigned to $6000 \mathrm{cal}$ a BC, is located $0.45 \mathrm{~m}$ w.e. from the abrupt enrichment in isotopes at $143.27 \mathrm{~m}$ w.e., which was assigned to $6400 \mathrm{cal}$ a BC (Table 1). The $1.8 \mathrm{~m}$ w.e. horizons between 145.2 and $143.4 \mathrm{~m}$ w.e. were significantly depleted. Two ${ }^{14} \mathrm{C}$ dates (Figs 4d, 5a and 9a) at the bottom of the $\mathrm{Bl} 2003$ ice core, along with strong $\delta^{18} \mathrm{O}$ isotope depletion and flow model dating suggest that the late glacial oscillation recorded in the $\mathrm{Bl} 2003$ ice core may be associated with the YD and it might have begun simultaneously with Greenland ice core records, but it was prolonged by more than millennium.

7.1.1.2. Significantly increased major ion concentrations. Up to 50 times for $\mathrm{Na}^{+}$(background), up to 45 times (background) for $\mathrm{Ca}^{2+}$ and $\mathrm{Mg}^{2+}$, up to 20 times for $\mathrm{SO}_{4}^{2-}$ (background) relative to subsequent periods are observed at the beginning and end of the most intensive depletion of isotopes, which occurred during the YD (Fig. 6). 
a
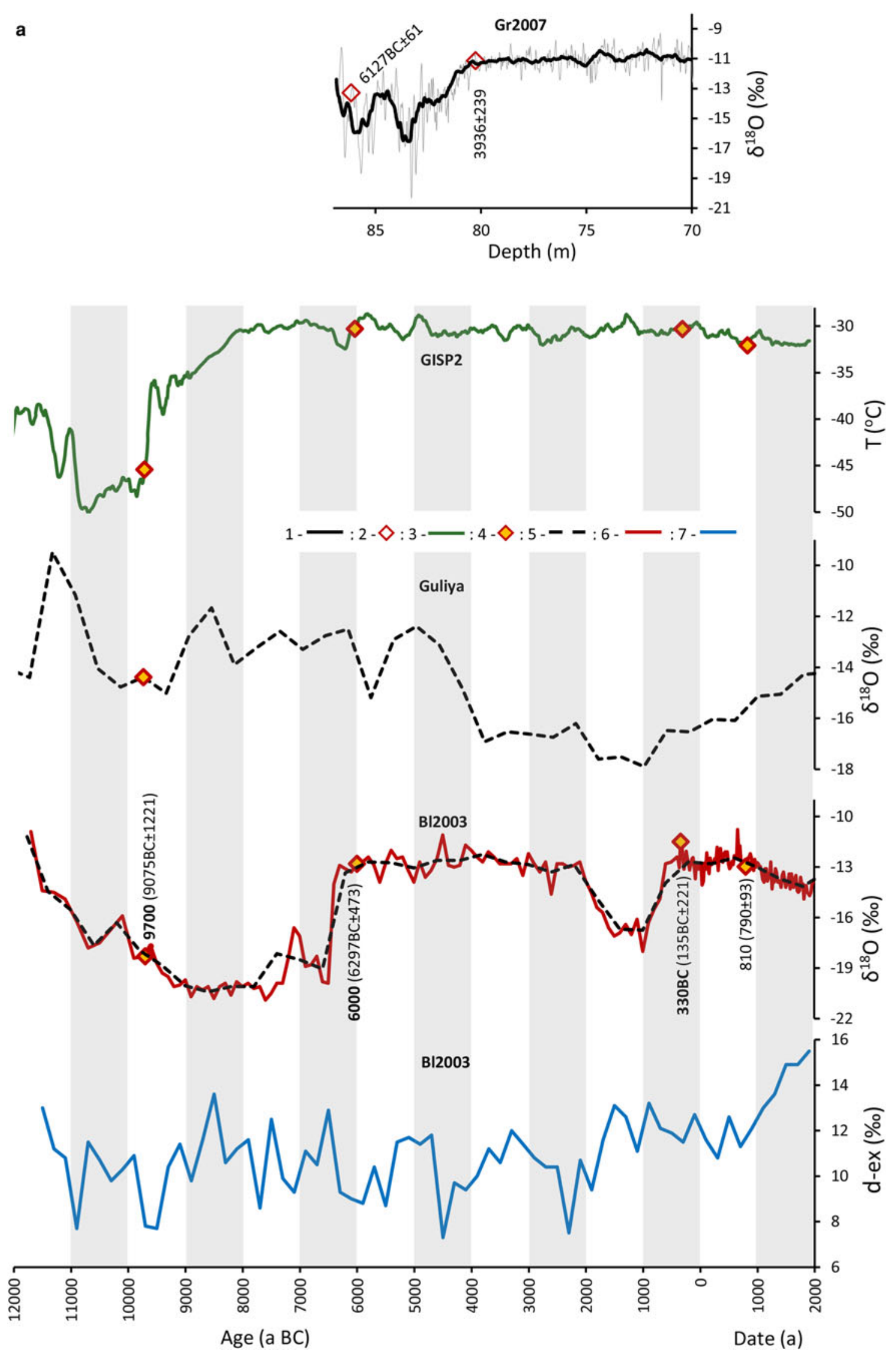

Fig. 9. Comparison of $\delta^{18} \mathrm{O}$ and d-ex records from the Altai, Bl2003 (to bedrock) ice core with $\delta^{18} \mathrm{O}$ records from inner Tien Shan, Grigor'eva ice core, Gr2007 (to bedrock, not dated) (Takeuchi and others, 2014), from Western Kunlun Shan, Guliya ice core (to bedrock) (Thompson and others, 1997) and from Altai, East Belukha ice core, Bl2001 (not to bedrock) (Henderson and others, 2006); with reconstructed mean air temperatures, $T\left({ }^{\circ} \mathrm{C}\right.$ ), from Greenland GISP2 (Alley, 2000), GISP2' (Kobashi and others, 2011), and from the Barnaul meteorological station, with air temperature deviations, $\Delta T\left({ }^{\circ} \mathrm{C}\right)$, from Greenland GISP2" (Vinther and others, 2009) and with summer air temperature deviations, $\Delta T \mathrm{~s}$ $\left({ }^{\circ} \mathrm{C}\right)$, reconstructed based on ring-width chronology from Siberia, Yamal, (Hantemirov and Shiyatov, 2002) for the last (a) 13700 years; (b) 2400 years of bi-decadal records and (c) 2000 years of decadal records. 1 is 15 -record moving averages of $\delta^{18} \mathrm{O} ; 2$ is ${ }^{14} \mathrm{C}$ measured age for Gr2007; 3 and 6 are reconstructed air temperature, $\delta^{18} \mathrm{O}$ and corresponding age (a BC, Date (a)); 4 is ${ }^{14} \mathrm{C}$ measured age for BI2003; 5 is four-centennial averages of $\delta^{18} \mathrm{O}$ for Guliya and Bl2003; 7 is bi-centennial averages of d-ex records from Bl2003. 
b
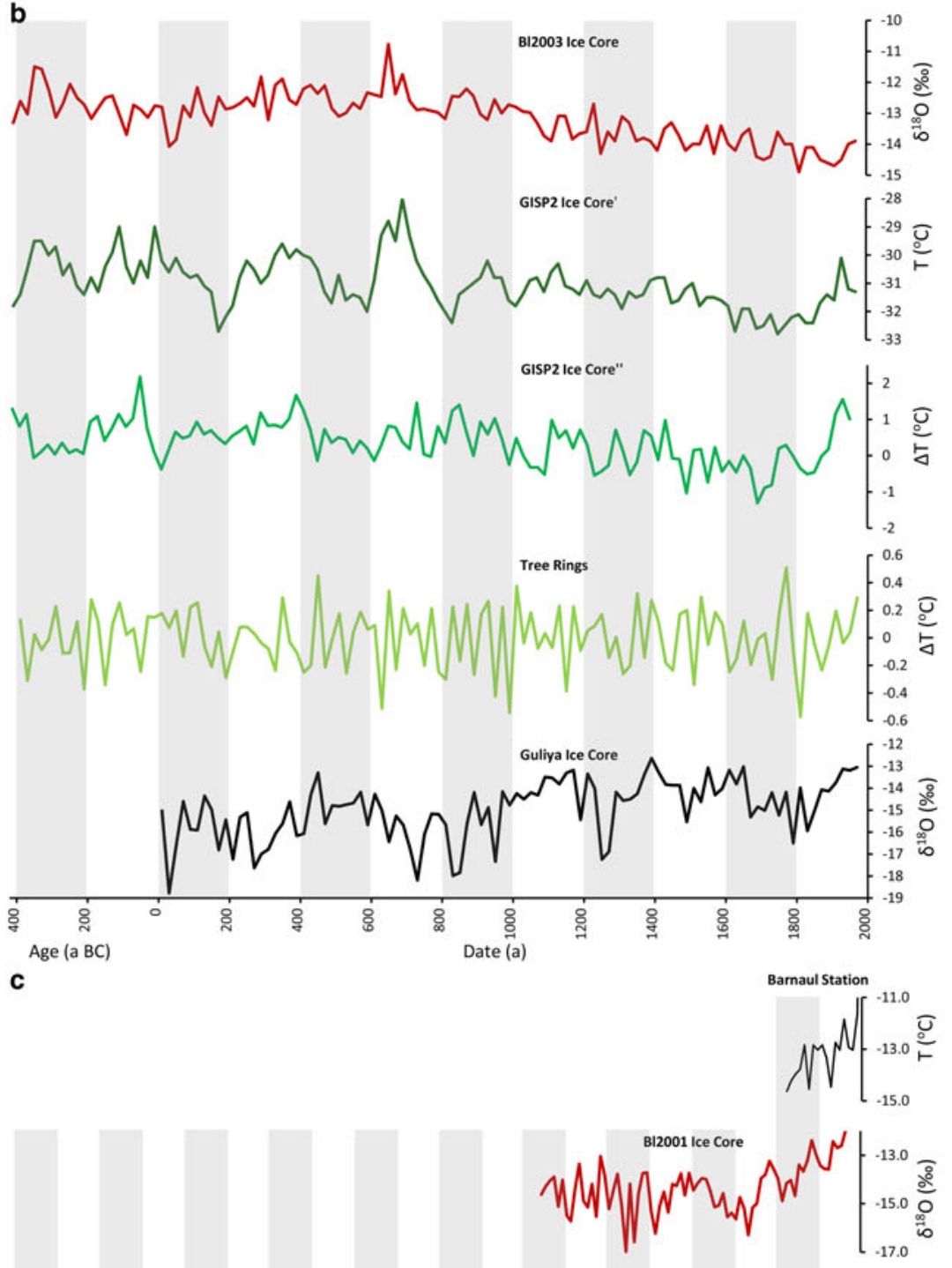

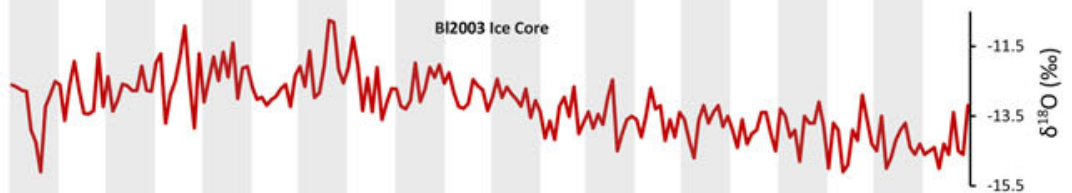
Gisp2 ice coré

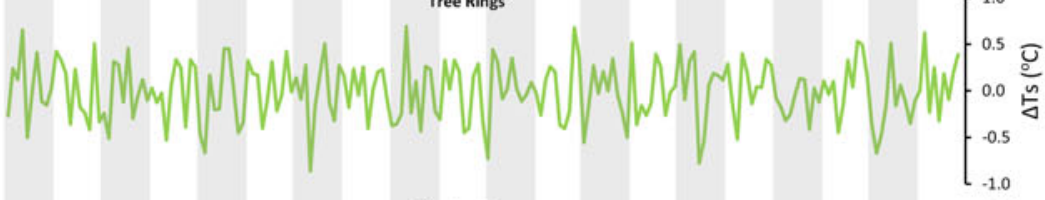

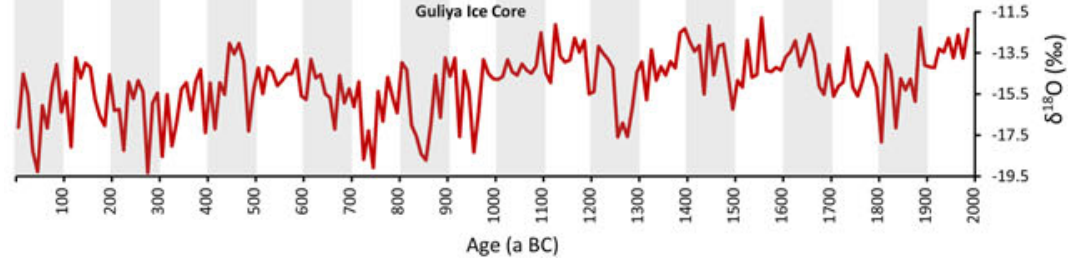

Fig. 9. (continued) 
The ion concentrations reveal variable magnitude and distribution during the $\mathrm{YD}$ in $\mathrm{K}^{+}$and $\mathrm{NO}_{3}^{-}$relative to maxima of $\mathrm{Ca}^{2+}, \mathrm{Mg}^{2+}, \mathrm{Na}^{+}, \mathrm{Cl}^{-}$and $\mathrm{SO}_{4}^{2-}$, pointing to different origin/causes of these two groups of ions/aerosols. A maximum in $\mathrm{K}^{+}$is not as significant as for $\mathrm{Ca}^{2+}, \mathrm{Mg}^{2+}$, $\mathrm{Na}^{+}, \mathrm{Cl}^{-}$and $\mathrm{SO}_{4}^{2-}$ during the warm to cold transition period and is delayed during the cold to warm transition period of the YD. There is no obvious maximum in $\mathrm{NO}_{3}^{-}$ during the warm to cold transition period of the YD.

During the YD, the transition from warm to cold and vice versa led to steepening pressure gradients, enhanced wind intensity and numerous dust storms with associated increases in $\mathrm{Ca}^{2+}, \mathrm{Mg}^{2+}, \mathrm{Na}^{+}, \mathrm{Cl}^{-}$and $\mathrm{SO}_{4}^{2-}$ concentrations. During the time of the most depleted isotope values, i.e. a period of minimum air temperatures, major ion concentrations (aerosol loading) decrease relative to the transition time from warm to cold and from cold to warm.

7.1.1.3. Air temperature and $\mathrm{d}$-ex values. Average air temperature was $6{ }^{\circ} \mathrm{C}$, reaching up to $9.0 \pm 2.7^{\circ} \mathrm{C}$, lower during the YD compared with the recent period (Figs 8a and b). The Bl2003 ice-core stable isotope profile exhibits the lowest air temperature during the YD with a possible deviation of $-12{ }^{\circ} \mathrm{C}$ relative to the recent period. During the YD average d-ex values ranged from 10.2 to $12.6 \%$ (Fig. 6b). These values are comparable with those for the Global Meteoric Water Line.

\subsubsection{Pre Boreal (PB) and Holocene Climate Optimum (HCO)}

7.1.2.1. $\delta^{18} \mathrm{O}$ enrichment. The first short and abrupt warming event (AWE1), associated with $\delta^{18} \mathrm{O}$ enrichment from -21.3 to $-16.6 \%$ was dated at $\sim 7300$ cal a BC, preceding the cool, Pre Boreal Oscillation event (PBO), 26900-6600 cal a BC (Fig. 5a(1); Table 1). Another warm period follows the large abrupt enrichment in $\delta^{18} \mathrm{O}$ from -20.3 to $-13.4 \%$ o indicative of the HCO (Figs $5 \mathrm{a}(1)$ and 6 ). The most intensive enrichment of $-10.5 \%$ occurred during the $\mathrm{HCO}$, pointing to an increase in air temperature at $\sim 5100-4600 \mathrm{cal}$ a BC. The Bl2003 ice-core records revealed that the HCO lasted from $\sim 6500$ to 3600 cal a BC over Siberia.

A short depletion in $\delta^{18} \mathrm{O}$ stable isotopes from -12.3 to $-14.7 \%$ o (Figs 4 and 5) with a ${ }^{14} \mathrm{C}$ radiocarbon date of 6297 $\pm 473 \mathrm{cal}$ a $\mathrm{BC}$ reveals a period with decreased air temperature referred to as the $8.2 \mathrm{ka}$ sudden cooling episode. The cold phase 26200 a BC was lasted by about 200 years across low- to mid-latitude regions (Zoller, 1960; Alley and others, 1997; Alley and Ágústsdóttir, 2005). However, the $\delta^{18} \mathrm{O}$ signal from Bl2003 ice core as well as from Guliya ice core at the 8.2 ka cooling episode was not as pronounced as in Greenland ice-core records (Figs 5a(1) and 9a).

7.1.2.2. Major ion. Sharp decreases in major ion concentrations are observed at the end of transition time of sharp isotope enrichment (Fig. 6). A delayed maximum in $\mathrm{K}^{+}$and $\mathrm{NO}_{3}^{-}$(relative to maximum in $\mathrm{Ca}^{2+}, \mathrm{Mg}^{2+}, \mathrm{Na}^{+}$, $\mathrm{Cl}^{-}$and $\mathrm{SO}_{4}^{2-}$ ) occurs during the large abrupt first warm events, AWE1, $7400 \mathrm{cal}$ a BC, after the YD.

During the $\mathrm{HCO}$, under the intensive $\delta^{18} \mathrm{O}$ enrichment, major ion content continued to drop reaching the lowest content $\sim 3000 \pm 200$ cal a BC after period before the severe centennial drought (SCD). Relative to $\mathrm{YD}$ the declining ion content, up to 30 times for $\mathrm{Na}^{+}$(maximum), from 10 times for $\mathrm{Ca}^{2+}$ and $\mathrm{Mg}^{2+}$, up to 15 times for $\mathrm{SO}_{4}^{2-}$ and just 2-3 times for $\mathrm{K}^{+}$and $\mathrm{NO}_{3}^{-}$are observed after of the most intensive enrichment of isotopes.

7.1.2.3. Air temperature and d-ex values. According to geomorphologic analysis (Koshkarova and Koshkarov, 2004) in north-central Siberia, the HCO warm event consisted of a winter warming of $3-9{ }^{\circ} \mathrm{C}$ and a summer warming of $2-6{ }^{\circ} \mathrm{C}$ compared with the modern period. The Altai ice-core mean records reveal a large temperature difference of $\sim 7^{\circ} \mathrm{C}$ between the $\mathrm{YD}$ and $\mathrm{HCO}$ and $\sim 5^{\circ} \mathrm{C}$ between the $\mathrm{HCO}$ and the SCD (Fig. 8). During the Holocene Thermal Maximum, bicentennial means reached the maximum positive deviation, exceeding on average, $1.5 \pm 2.7^{\circ} \mathrm{C}$ relative to recent times, and $2.0 \pm 2.7^{\circ} \mathrm{C}$ relative to the modern period (Fig. 8b). During the warmest periods of the $\mathrm{HCO}$ with the highest bicentennial $\delta^{18} \mathrm{O}$ mean $(-10.53 \%$ ) d-ex values drop to their lowest values and the bicentennial dex mean values reach a minimum of $6.1 \%$ (Fig. 9a).

\subsubsection{Severe centennial drought}

7.1.3.1. $\delta^{18} \mathrm{O}$ depletion. The $\mathrm{Bl} 2003$ ice-core record reveals significant and prolonged depletion in isotopes from $\sim 2000$ to $200 \mathrm{cal}$ a BC (Figs 4, 5a(1), 6a and 9a; Table 1), concurrent with periods of SCD observed in North Africa, SE. Asia and N. America from 2400 to 1800 years BC (Claussen and others, 1999; Booth and others, 2005; Arz and others, 2006; Davis and Thompson, 2006; Parker and others, 2006; Menounos and others, 2008; Chun and others, 2011). The dating of the SCD corresponds with prolonged depletion in Guliya ice-core stable isotope records (Thompson and others, 1997). However, the SCD event was not pronounced in the GISP2 ice-core signal (Fig. 9a).

7.1.3.2. Major ions. Elevated ion concentrations (relative to their declines in the $\mathrm{HCO}$ ) up to 5 times for $\mathrm{Na}^{+}$, $\mathrm{Cl}^{-}$and $\mathrm{SO}_{4}^{2-}, 2-3$ times for $\mathrm{Ca}^{2+} \mathrm{Mg}^{2+}, \mathrm{NO}_{3}^{-}$and $\mathrm{K}^{+}$are observed at the beginning of the SCD during the second period of intensive isotope depletion, i.e. during the sharp transition from warm to cold conditions in the SCD. After this maximum, the major ion contents moderately and slowly decreased to pre-industrial low levels and have insignificant variability. There is no maximum in ion content at the end of SCD during the transition from cold to warm conditions as was observed during the YD.

7.1.3.3. Air temperature and d-ex values. Air temperatures declines a second time after the $\mathrm{YD}$, down $5{ }^{\circ} \mathrm{C}$ from the $\mathrm{HCO}$, however, not reaching the YD minimum of $\sim 1.5^{\circ} \mathrm{C}$. Air temperatures are about $\sim 3.5^{\circ} \mathrm{C}$ lower than modern values (Fig. 8). D-ex values began to increase from about the time of the SCD lowest temperatures and reach their modern values, exceeding 14\%o (Fig. 6).

\subsubsection{Medieval Warm Period (MWP) during Prolonged Warm Period (PWP)}

7.1.4.1. $\delta^{18} \mathrm{O}$. The enrichment in $\delta^{18} \mathrm{O}$, from -19.4 to $-10.1 \%$, after the SCD (Fig. 4) $\sim 600$ cal a BC lasted until $\sim 1100$ AD, revealing a warm period, which includes the MWP, which began from 640 AD (Figs 5a(2,3), 6a, 9a and b). The corresponding ${ }^{14} \mathrm{C}$ date is $790 \mathrm{AD} \pm 93$ consistent with flow model dating and peaks in volcanic eruptions 
(Table 1). The most intensive enrichment in $\delta^{18} \mathrm{O}$ (up to $-8.9 \%$ ) in the Bl2003 ice-core record occurred $\sim 660$ to 680 AD with a dating discrepancy of $5 \%$ (Table 3 ).

After isotope ratios enriched to the Medieval Thermal Maximum values, further cooling followed gradually with periods of more or less depleted isotopes. There is an observed negative trend in bidecadal isotope means since the Medieval Thermal Maximum (Figs 9b and 6a).

The end of the MWP in the $\mathrm{Bl} 2003$ ice-core record was associated with the beginning of a mild and continuous depletion in isotopes $1100 \mathrm{AD}$, which is in accordance with the end of the MWP estimated by Briffa and others (1990), Mackay and others (2005) and Mann and others (2009).

Comparison of bidecadal mean stable isotope ratios revealed similar distributions in the $\mathrm{Bl} 2003$ and GISP2 icecore records (Kobashi and others, 2011) from $400 \mathrm{cal}$ a BC to $1820 \mathrm{AD}$ especially for the MWP. Analysis of a tree ring chronology also revealed an increase in reconstructed summer air temperatures (Hantemirov and Shiyatov, 2002) during the Medieval Thermal Maximum (Fig. 9b).

7.1.4.2. Major ions (Fig. 6). After the elevated ion concentration during the SCD, their content decreased with moderate variability and did not significantly change till the industrial period (IP).

7.1.4.3. Air temperature and d-ex values. During the MWP as well as in the $\mathrm{HCO}$, air temperature was higher, on average $\sim 1.5^{\circ} \mathrm{C}$, relative to the recent and modern warm period (MoWP) (Fig. 8). D-ex values fluctuated on average between 10 and 14\%o (Figs 6 and 9a).

\subsubsection{Little Ice Age}

7.1.5.1. $\delta^{18} \mathrm{O}$. The LIA appears to span the period 1400 to $1870 \mathrm{AD}$ according to GISP2 chemical records in Europe (Mayewski and others, 1993; Meese and others, 1997; Bradley, 2000) and from 1500 AD in China ( $\mathrm{Li}$ and $\mathrm{Ku}$, 2002), which experienced lower temperatures compared with the 20th century. There are several minima with warming intervals during the LIA (Mayewski and others, 1993; Meese and others, 1997). In Siberia, the LIA lasted from 1480 until 1880 AD based on data from sediments in the Teletskoe Lake (Butvilovskii, 1993; Panyushkina and others, 2000; Andreev and others, 2007).

The mild, continuous depletion in the middle part of the $\mathrm{Bl} 2003$ ice core, around the middle of the 15th century, is considered as the LIA (Figs 6a and 9c). The LIA is not obviously pronounced in the Altai Bl2003 ice-core isotope records. Depleted isotopes during the middle of the 15th century were followed by relatively enriched isotope values until the end of the 15th century. Following this, isotope depletion occurred near the turn of each century, lasting until the middle of the 20th century (Figs 6a and 9c).

7.1.5.2. Ion concentration. It was relatively low with periods of greater or lesser concentration. The end of the 15th/beginning of 16th centuries and the end of 19th/beginning of the 20th centuries are characterized by low concentrations of major ions. This was accompanied by the most depleted isotope content during the LIA, i.e. low temperatures (Fig. 6).

7.1.5.3. Air temperature. At the beginning of the 15th century, the climate was on average, $2{ }^{\circ} \mathrm{C}$ cooler compared with the recent period based on the Bl2003 ice-core data (Fig. 8).

\subsubsection{PI and IPs including modern and recent}

7.1.6.1. $\delta^{18}$ O. During the MoWP from 1973 to 2003, a shift in climate appears marked by an observed enrichment in stable isotope values. However, the most enriched records are in the upper part of the $\mathrm{Bl} 2003$ ice core, up to $-9.8 \%$. Enrichment of stable isotope values in the $\mathrm{Bl} 2003$ ice core increases significantly from the beginning of the 1990s, i.e. during the recent warm period (ReWP) from 1993 to 2003 (Figs 5b and 6a). These values were not exceeded by any of those observed for the last 1000-1500 years. An exception is a short period with several enriched records, up to $-9.0 \%$, at the middle of the 18th century (Figs $5 b(3)$ and 9c).

At the beginning of glacier generation (or regeneration), isotope records were more enriched than during the 30 years MoWP and then during the 10 years ReWP (means for: MoWP is $\delta^{18} \mathrm{O}_{1973-2003}=-14.1 \%$ and for ReWP: $\delta^{18} \mathrm{O}_{1973-1993}=-13.3 \%$; Table 2). At the bottom of the $\mathrm{Bl} 2003$ ice core, from 145.865 to $145.75 \mathrm{~m}$ w.e. depth several isotopically enriched records of up to $-10.9 \%$ were revealed. During the $\mathrm{HCO}$ and MWP centennial mean isotope values are even higher, by up to $-8.9 \%$, than the 30 years MoWP and the 10 years ReWP means (Fig. 9a).

7.1.6.2. Major ions. Elevated sulfate and nitrate levels in the upper $17.8 \mathrm{~m}$ w.e. of the core are related to the Industrialization (IP) as of the early1950s, marked by an increasing trend ( $p \leq 0.001, F$-stat result using log-transformed concentrations) (Olivier and others, 2006; Joswiak, 2008) (Figs $6 \mathrm{~g}$ and $\mathrm{f}$ ). Despite the positive trend in the sulfate/ nitrate time series since the early 1950s, a decrease in concentrations occurred in the early 1990s during the ReWP reflecting a combination of several factors, including a short-run de-industrialization period subsequent to the dissolution of the Soviet Union in 1991, and global reduction of atmospheric sulfate in the early 1990s from decreased coal use and production (Stern, 2005). Low-level concentrations below $17.8 \mathrm{~m}$ w.e. provide insight into the PI background of atmospheric concentrations.

7.1.6.3. Air temperature and d-ex values. During the MoWP air temperature exceeded air temperatures during the YD, SCD, LIA and pre-IPs, it was about the same as during the beginning of IP, and lower by $1.0^{\circ} \mathrm{C}$ relative to $\mathrm{HCO}$ and the MWP. During the ReWP air temperature is lower by just $\sim 0.5{ }^{\circ} \mathrm{C}$ than during the Holocene Thermal Maximum and the MWP (Figs 8a and b).

The d-ex values reach their maximum, on average significantly exceeding $14 \%$ and sometimes as high as $22 \%$ during the PI and IP till the end of 1970s. From the beginning of the 1980 s when a sharp decrease in d-ex values is observed, d-ex values varied from 10 till $16 \%$.

\subsection{Comparison analysis of Bl2003 ice-core records with other paleo-climatic records}

\subsubsection{East Belukha ice core, Siberian Altai}

In July 2001, another ice core (BI2001; not to bedrock) was obtained by a Swiss-Russian team from the saddle between 
the East and West Belukha peaks $\left(49^{\circ} 48 \mathrm{~N}, 86^{\circ} 34 \mathrm{E} ; 4062 \mathrm{~m}\right.$ a.s.I.) (Olivier and others, 2003, 2006; Henderson and others, 2006; Eichler and others, 2009, 2011) (Fig. 1c). The Bl2001 depth/age scale was derived for the $69.1 \mathrm{~m}$ w.e. core based on the 1963 peak in tritium and the record of ${ }^{210} \mathrm{~Pb}$ radioactive decay since 1815 using modeled annual layer thinning (Haefeli, 1961). The average annual accumulation was reported as $0.560 \mathrm{~m}$ w.e. (Olivier and others, 2003), from the surface to $69.1 \mathrm{~m}$ w.e. (reference horizon of Tambora eruption) covering the time period, 1815-2001.

A lower accumulation rate was obtained from the West Belukha Plateau surface to bedrock ice core, Bl2003 (i.e. $0.34 \mathrm{~m}$ w.e. for the period, 1815-2001) in comparison with that reported by Olivier and others (2003). Accumulation differences are likely the result of variability in wind/snow redistribution caused by local orographic effects created by the two-steep slopes of the West and East Belukha peaks on the saddle where the Bl2001 was drilled, while the BI2003 ice core was obtained from an open plateau (Figs $1 \mathrm{~b}$ and c).

Marked events including the Mt. Pinatubo eruption in 1991, nuclear detonation maximum in 1963, the Novarupta eruption in 1912, the Tunguska event in 1908, the Mt. Krakatoa eruption in 1883, major dust storms in 1842 and the Tambora eruption in 1815, among others (Table 1) are preserved in both cores validating the depth/ age scale developed for the $\mathrm{Bl} 2003$ core.

Decadal means of stable isotope ratios from the $\mathrm{Bl} 2001$ core were developed for the period, 1250-1980 (Eichler and others, 2009), (Fig. 9c). Estimated uncertainty of the $\mathrm{Bl} 2001$ core dating increases from $<1$ year at the $\delta^{3} \mathrm{H}$ peak to $\sim 6$ years at 1940, and to $\sim 25$ years at 1815 (Olivier and others, 2004), i.e. for the period covered by radioactive decay of ${ }^{210} \mathrm{~Pb}$. Discrepancies in dating the Bl2003 icecore records by different techniques is also $\sim 1$ year at the 1963 depth and 7-9 years at the 1815 depth (Table 3).

Comparison of the decadal mean stable isotope ratios revealed similar distributions in the $\mathrm{Bl} 2001$ and $\mathrm{Bl} 2003$ icecore records from 1250 to 1850 (Fig. 9c). The discrepancy in the distribution of the high and low values in the decadal means is within the uncertainty/discrepancy in dating the Bl2001 core (25 years at 1815; Olivier and others, 2004) and the $\mathrm{Bl} 2003$ core (7-9 years at 1815; Table 3). The variability in decadal means of $\delta^{18} \mathrm{O}$ values obtained from the $\mathrm{Bl} 2001$ and $\mathrm{Bl} 2003$ ice cores is about the same $(\sigma=1.0$ and $0.6 \%$ ). Reconstructed NovemberMay air temperature from the Bl2001 ice-core stable isotope records is based on data from Barnaul meteorological station (Eichler and others, 2009). Eichler and others (2009) found a $\delta^{18} \mathrm{O} /$ air temperature slope of $(0.88 \pm 0.36) \%{ }^{\circ} \mathrm{C}^{-1}$ for decadal means in May-November monthly air temperature; our analysis revealed an air temperature $/ \delta^{18} \mathrm{O}$ slope of $(0.9 \pm 0.08){ }^{\circ} \mathrm{C}^{\circ}{ }^{-1}(\operatorname{Eqn}(6))$. The slope in the inverse relationship between $\delta^{18} \mathrm{O} /$ air temperature is $(1.1 \pm 0.08) \%{ }^{\circ} \mathrm{C}^{-1}$. Thus, both air temperature reconstruction techniques reveal slopes within the uncertainty in the $\delta^{18} \mathrm{O}$-surface air temperature regression.

From the middle of the 18th century, stable isotope records from the $\mathrm{Bl} 2001$ ice core reveal significant enrichment until the 1980s. Stable isotope records from the Bl2003 ice core do not reveal a significant enrichment trend until the middle of the 20th century, with the most significant enrichment from the end of the 1980s to the beginning of the 1990s (Figs 6a and 9c). The distribution of stable isotopes from the $\mathrm{Bl} 2003$ ice-core records is in accordance with air temperature reconstructions from Okamoto and others (2011), which are based on stratigraphic analysis of the Bl2003 ice core.

The difference in decadal means of $\delta^{18} \mathrm{O}$ is explained by the more significant fraction of radiation melt and partial percolation in Bl2001 at the upper part of the Bl2001 core (Henderson and others, 2006). Significant association between thicknesses of radiation crust in annual layers in $\mathrm{Bl} 2001$ and reconstructed air temperatures (Eichler and others, 2009) supports our explanation that the effect of solar radiation on snow melt and consequent stable isotopes is more significant at the Bl2001 drilling site than at the Bl2003 site. A decreased fraction of radiation melt at the insignificantly higher elevated BI2003 drill site is likely responsible for the more depleted mean stable isotope ratio since the middle of the 18th century. The difference in radiation melt between the $\mathrm{Bl} 2001$ and Bl2003 drilling sites might be caused by differences in topography. Bl2001 is located on the saddle of a narrow field between the Belukha and West Belukha peaks (Fig. 1). Radiation melt and percentage of percolation with consequent freezing is more intense at B12001 than at $\mathrm{Bl} 2003$ because of multiple reflections of shortwave radiation from surrounding slopes covered by snow with high albedo, which significantly increases the diffuse and total radiation, especially under intense cloudiness. With the water phase change, isotopic fractionation enriches stable isotopes by $2-3 \%$ in the solid phase (e.g. O'Neill, 1968; Arnason, 1969; Nakawo and others, 1993).

Different wind/snow redistributions at the two drill sites could also cause the difference in decadal means of $\delta^{18} \mathrm{O}$. Higher snow accumulation at Bl2001 than at Bl2003 is a result of snow redistributed from nearby slopes. The additional snow brought from surrounding slopes at Bl2001 generally accumulated during the warm season (when the precipitation maximum occurs), increasing the decadal stable isotope means.

7.2.2. Greenland, GISP2 (Alley, 2000; Vinther and others, 2009; Kobashi and others, 2011); Western Kunlun Shan, Guliya (Thompson and others, 1997), Inner Tien Shan, Grigor'eva (Takeuchi and others, 2014) ice cores and northwestern Siberia, ring-width chronology (Hantemirov and Shiyatov, 2002) (Fig. 9) 7.2.2.1. YD and 8.2 ka event. Analysis of stable isotopes from the three surface to bedrock ice cores from different parts of central Asia and Greenland (Guliya, Bl2003 and GISP2) reveal the YD. The exception is Gr2007, where the ${ }^{14} \mathrm{C}$ radiocarbon measurements from the surface to bedrock reveal the existence of grass during the YD (Takeuchi and others, 2014). The duration and intensity of this cool period differs geographically. The most intense drop and following abrupt rise in air temperature occurred over Greenland (Fig. 9a; Alley, 2000). The air temperature change was $\sim 10^{\circ} \mathrm{C}$, while in the West Siberia, air temperature changed $\sim 7-8{ }^{\circ} \mathrm{C}$ (sum of negative and positive deviations; Fig. $8 \mathrm{~b}$ ) and the depletion in isotopes was $\sim 9 \%$. The Guliya ice core demonstrates a weak depletion $\sim 4-5 \%$.

The ${ }^{14} \mathrm{C}$ radiocarbon measured layer at the bottom of the $\mathrm{Bl} 2003$ ice core, of $(9075 \pm 1221)$ cal a BC assigned as 9700 cal a BC is the beginning of isotope depletion in the BI2003 ice core, while the $(9075 \pm 1221)$ cal a BC in the GISP2 ice core corresponds to the end of the cool period of the $\mathrm{YD}$ in Greenland and to the middle part of the YD cool period in 
the Western Kunlun, Guliya (Fig. 9a). The Western Siberia, Altai, had the most prolonged cool period of YD. In the Western Kunlun Shan, enrichment of isotopes after the YD cool period was not so intensive as in GISP2 or BI2003. The depletion of isotopes/air temperatures over $8.2 \mathrm{ka}$ is observed in all four surface-to-bottom cores, including Gr2000.

7.2.2.2. SCD. The Guliya and $\mathrm{B} \mid 2003$ records contain a prolonged period in isotope depletion of approximately the same intensity (i.e. from 12 to $18 \%$ o) during the SCD, which is not pronounced in GISP2 records. The Guliya ice core shows an earlier time for the beginning of gradual isotopes depletion than the $\mathrm{Bl} 2003$ core, but the same period for the most intense depletion during the SCD (Fig. 9a).

\subsubsection{The last 2400 years (MWP, LIA, PIP, IP, MoWP,} RWP). For the last 2400 years, the distribution of bidecadal/decadal means in the Bl2003 stable isotope is in the best accordance with bidecadal/decadal means of reconstructed air temperature from GISP2 (Vinther and others, 2009; Kobashi and others, 2011) (Figs 9b and c). The correlation reaches 0.53 with data developed by Kobashi and others (2011) or 0.40 with data developed by Vinther and others (2009). The MWP is pronounced in both sets of data with a maximum in air temperature $/ \delta^{18} \mathrm{O}$ ratio at $\sim 640-700$ AD.

There is a discrepancy between Bl2003 and GISP2 around the 20th century when reconstructed data from GISP2 shows an increase in air temperatures from the end of 19th to the beginning of 20th century, i.e. the end of the LIA, while the $\mathrm{Bl} 2003$ ice-core records demonstrate enrichment in isotopes from the middle of 20th century (Figs 9c and b).

Bidecadal/decadal means in stable isotope records from the Guliya ice core (Thompson and others, 1997) do not show a significant correlation with corresponding BI2003 ice-core records for the last 2000 years, however there are similar periods in $\delta^{18} \mathrm{O}$ enrichment (e.g. 440, 980, 1660) and depletion (e.g. 40 AD, 1200, 1260, 1500, 1810) in both cores (Fig. 9c). Summer air temperature deviations reconstructed from the tree ring chronology (Hantemirov and Shiyatov, 2002) are similar in distribution to Bl2003 $\delta^{18} \mathrm{O}$ records, with periods of isotope enrichment/high summer temperatures (e.g. 130, 450, 660, 980, 1180, 1660, 1830) and depletion/low summer temperatures (e.g. 40, 530, 640, 1110, 1200, 1380, 1730, 1810, 1920, 1940) (Fig. 9c). Neither Bl2003 ice core $\delta^{18} \mathrm{O}$ records nor tree ring chronology from the northwest Siberia demonstrate air temperature growth from the end of 19th century.

\section{DISCUSSION}

\subsection{The post-depositional processes}

Temperature measured in the $171 \mathrm{~m}$ deep borehole suggests that West Belukha Plateau lies in the cold recrystallization zone, where any meltwater subsequently refreezes below the surface and there should not be ion diffusion in the $\mathrm{Bl} 2003$ ice core. Stratigraphic analysis of Bl2003 ice core indicates an absence of percolation. Analysis of the $\delta^{18} \mathrm{O} /$ $\delta \mathrm{D}$ relationship in the $\mathrm{B} / 2003$ ice core also indicates an absence of intensive melt and consequent percolation. The varied slopes the in $\delta^{18} \mathrm{O} / \delta \mathrm{D}$ relationship do not approach typical sublimation/evaporation slopes, suggesting it is unlikely that evaporative/sublimation changes occur at the site. Snow/wind redistribution over the open West Belukha Plateau is just one of the post depositional processes that could insignificantly impact on ice-core records on the Belukha Plateau, most probably during winter. According to automatic twice-daily measured snow surface level, there is no sign of wind redistribution during the warm season till October (Aizen and others, 2005). Furthermore, according to stratigraphy analysis, no significant post-depositional effects were apparent in the records from the Bl2003 ice core, as stable isotope records from the surface to the $51 \mathrm{~m}$ w.e. yield well-preserved seasonal signals of $\delta^{18} \mathrm{O}$.

\subsection{The YD event}

The YD event recorded in the Bl2003 core likely began simultaneously with the YD in Greenland ice-core records, but it was more prolonged. Our results of the prolonged YD dating through Bl2003 ice-core records are in accordance with Rhodes and others (1996), Yang and others (2004), and Okishev (2011) results. Furthermore, according to Saarnisto (2000) the maximum extent of western Siberian glaciation during the LGM as well as the YD was reached one millennium later than the extent of maximum glaciation in Europe.

According to Steffensen's and others (2008) results, the precipitation moisture source of Greenland switched within 1-3 years over the YD transition and initiated an abrupt change of the Greenland air temperature. Steffensen and others (2008) suggest that a northern shift of the Intertropical Convergence Zone could be the trigger of these abrupt shifts of Northern Hemisphere atmospheric circulation. We assume that the changes in YD air temperatures recorded in the $\mathrm{Bl} 2003$ ice core were also caused by changes in atmospheric circulation/pressure, with consequent changes in sources of moisture, wind speed and in atmospheric dust loading from expanded Asian deserts (Kazakh steps, Muyun Kum, Gobi and Taklamakhan). Dust, which could explain the prolonged YD event, was intensively eluted and accumulated in Asian deserts after the LGM when Siberian and Central Asian glaciers melted. The transition from warm to cold and vice versa led to steepening pressure gradients resulting in enhanced wind and frequent dust storms with associated increases in $\mathrm{Ca}^{2+}, \mathrm{Mg}^{2+}, \mathrm{Na}^{+}, \mathrm{Cl}^{-}$ and $\mathrm{SO}_{4}^{2-}$ concentrations. During the time of the most depleted isotope values in YD (minimum air temperatures), major ion concentrations decreased, relative to the timing of changes in air temperatures, and intrusion of dust from Asian deserts to the Siberian Altai was not as intense as during the transitional time. During the minimum air temperatures of the YD, regional convective processes were reduced and mineral dust loading weakened.

Values of d-ex comparable with the Global Meteoric Water Line during the YD suggest that the western, northwestern and northern air masses originating over the Atlantic Ocean are primarily responsible for bringing precipitation to the Altai Mountains. This precipitation is not significantly modified by recycled moisture.

Uneven variability in $\mathrm{K}^{+}$and $\mathrm{NO}_{3}^{-}$ions relative to $\mathrm{Ca}^{2+}$, $\mathrm{Mg}^{2+}, \mathrm{Na}^{+}, \mathrm{Cl}^{-}$and $\mathrm{SO}_{4}^{2-}$ concentrations during the $\mathrm{YD}$ suggests their different origin. $\mathrm{K}^{+}$and $\mathrm{NO}_{3}^{-}$are the most suitable biomass burning proxies (Eichler and others, 2011), while $\mathrm{Ca}^{2+}, \mathrm{Mg}^{2+}, \mathrm{Na}^{+}, \mathrm{Cl}^{-}$and $\mathrm{SO}_{4}^{2-}$ are suitable as dust storm proxies for the Siberian Altai ice cores. A maximum in $\mathrm{K}^{+}$ and $\mathrm{NO}_{3}^{-}$occurs not during the $\mathrm{YD}$, but during the large abrupt warm events after the YD. We assume there was 
insufficient biomass available for burning during the time of the most depleted isotopes/lowest temperatures of the YD. The enriched isotopes associated with increased temperature during the AWE activated biomass growth with consequent burning under, most probably, dry and still windy conditions.

\subsection{Holocene Climate Optimum}

We suggest that during the $\mathrm{HCO}$, high moisture availability in the Altai was associated with intrusions of Atlantic air masses as well as with moisture originating from the Pacific, evidenced by $\delta^{18} \mathrm{O}$ and $\mathrm{d}$-ex (Aizen and others, 2005 , 2006) that maybe associated with the Eastern Asian Pacific summer monsoon. Continental recycled moisture was negligible, probably caused by high air humidity during one of the warmest periods in the Holocene. Combined paleo-evidence (Petit-Maire and others, 1994) suggests that the Eastern Asian monsoon penetrated more than $300 \mathrm{~km}$ northwestwards into Inner Mongolia between $\sim 7500 \mathrm{BC}$ and $3000 \mathrm{BC}$ exceeding its modern limit of extension. This agrees with Ricketts and others (2001) data from an $\sim 8000$ years record of hydrological change within Issyk Kul Lake (inner Tien Shan) based on sedimentary, faunal and geochemical evidence from piston cores, attributing high moisture availability in the early Holocene period to strengthening Asian and Indian summer monsoons. The sharp drop in ion content in the BL2003 ice-core records could be associated with increased precipitation during the $\mathrm{HCO}$ relative to the YD.

\subsection{SCD, MWP and LIA}

Water cycle changes in the Siberian Altai resulted in more cold and probably arid conditions from $\sim 2000$ to $600 \mathrm{cal} \mathrm{a}$ $\mathrm{BC}$ yielding a transition to the SCD. The elevated concentrations of $\mathrm{K}^{+}$and $\mathrm{NO}_{3}^{-}$during the beginning of the SCD cold period may be associated with sufficient biomass developed during the preceding wet and warm period of the HCO. The biomass burning was intensified during the subsequent dry SCD that resulted in increased $\mathrm{K}^{+}$and $\mathrm{NO}_{3}^{-}$concentration in the $\mathrm{Bl} 2003$ core.

We suggest that the fraction of re-evaporated moisture from the Aral-Caspian endorheic basin began to increase during the SCD with a maximum fraction during the PI. However, the Oceanic sources of moisture are still the prevalent sources during the SCD and MWP with insignificant fractions of continental (or recycled) moisture. The high values of $\mathrm{d}$-ex, exceeding $14 \%$ o during the LIA, are associated with an increased fraction of precipitation of inter-continental origin in the Altai.

\subsection{PI and IP}

During the ReWP air temperature almost reaches $\mathrm{HCO}$ and MWP high temperatures. The maximum values of d-ex during the PI and IPs, till the end of 1970s, suggest that intercontinental moisture was the main source of precipitation. We suggest that from the beginning of the 1980s oceanic moisture again became the prevalent source.

\section{CONCLUSIONS}

Radiocarbon analysis of the POC fraction, stable isotope records and derived temperature estimations from the
Bl2003 ice core suggests that modern Altai glaciers were re-generated during the $\mathrm{YD}$, when air temperatures in the Siberian Altai were, on average, $\sim 6{ }^{\circ} \mathrm{C}$ lower than during the Recent Warming Period, and reveal an abrupt $\sim 7^{\circ} \mathrm{C}$ increase in air temperature after the end of the YD.

In addition, during the YD, Bl2003 major ion records exhibit the highest concentrations displayed in the entire ice-core record. Following the Younger Dryas, major ion concentrations decrease reaching the lowest mean levels during the modern/recent period. The exceptions to these trends are sulfate and nitrate, which begin to increase in concentration during the early 1950s, reflecting modern industrialization. Bl2003 results are in accord with analyses from Greenland (Mayewski and others, 1997; Taylor and others, 1997), Antarctica (Jouzel and others, 1996) and tropical alpine (Thompson and others, 1995) ice cores, which also show high concentrations of mineral dust during the YD cold period. Elevated major ion concentrations during the YD can be explained by the intercontinental location of the Altai Mountains and large mineral dust sources from Asian deserts.

The $\mathrm{Bl} 2003 \delta^{18} \mathrm{O}$ signal, along with ${ }^{14} \mathrm{C}$ radiocarbon measurements, reveals a period with decreased air temperature corresponding with the 8.2 ka sudden cooling episode. In addition, the $\mathrm{Bl} 2003$ ice-core records, as well as the Guliya ice-core records (Thompson and others, 1997) reveal the prolonged period in isotope depletion of approximately the same intensity from $\sim 2000$ to 600 a BC, which is associated with the Severe Continental Drought. During this period air temperatures, on average, were $\sim 4.5^{\circ} \mathrm{C}$ lower than during the Recent Warming Period.

The subsequent cold period from the middle of the 15th century until the middle of the 20th century was mild and was associated with the LIA, when air temperatures were, on average, $\sim 2{ }^{\circ} \mathrm{C}$ lower than during the recent period in the Siberian Altai.

The Altai glaciers survived the AWEs of the Holocene Climatic Optimum, which lasted over Siberia from 6500 to $3600 \mathrm{cal}$ a BC, through the MWP (640-1100 AD) and MoWP (1973-2003). The most intense enrichment of $\delta^{18} \mathrm{O}$ in the Bl2003 ice core is related to $\sim 660 \mathrm{AD}$, the Medieval Thermal Optimum. The Modern Warm Period, 1973-2003, represents a shift in Altai climate marked by an observed increase in air temperature, a weakening in the intensity of the westerlies and increases in inputs of recycled moisture from intercontinental Asia, which severely impacts glaciological conditions in the Altai. Despite these recent significant changes, recent air temperatures (1993-2003) are, on average, $0.5^{\circ} \mathrm{C}$ lower than air temperatures estimated during the MWP and Holocene Climate Optimum. During the current Altai's neo-glaciation existence, colder than modern periods occurred for $\sim 6.5 \mathrm{ka}$ during the Younger Dryas, PBO event and SCD, and periods warmer than modern periods occurred for $\sim 6.5 \mathrm{ka}$ including during the $\mathrm{HCO}$ and Medieval Warm Period.

\section{ACKNOWLEDGEMENTS}

This research was supported by grants from the National Science Foundation ATM-0754479 and ATM-0754644, the US Department of Energy (DE-A107) and by Oasis Project of the RIHN, Kyoto, Japan. The authors thank T. Prokopinskaya for her inestimable contribution in organizing the scientific expeditions. We also thank all expedition 
members, especially: A. Lushnikov, A. Chebotarev, A. Surazakov, M. Yoshihiro, M. Kenichiro, A. Takahashi, J. Uetake, T. Yamazaki, V. Yakubovskiy and V. Podoprigora, the chief pilots of the Russian helicopter MI-MTV from the Altai Regional Rescue Department. We also thank E. Korotkikh, D. Dixon, and S. Sneed for valuable contributions to the Belukha ice-core processing and analysis in the ice-core laboratory of the Climate Change Institute, University of Maine. We appreciate the useful comments and suggestions of scientific reviewers and editors.

\section{REFERENCES}

Aizen VB (2011) In Singh VP, Singh P and Haritashya UK eds. Encyclopedia of Snow, Ice and Glaciers. Springer, the Netherlands. Chapters 38; 39; 510; 813; 1179

Aizen VB and 5 others (2005) Stable-isotope time series and precipitation origin from firn cores and snow samples, Altai glaciers, Siberia. J. Glaciol., 51(175), 637-654

Aizen VB and 5 others (2006) Climatic and atmospheric circulation pattern variability from ice-core isotope/geochemistry records (Altai, Tien Shan and Tibet). Ann. Glaciol., 43, 49-60

Aizen VB, Kuzmichenok VA, Surazakov AB and Aizen EM (2007) Glacier changes in the Tien Shan as determined from topographic and remotely sensed data. J. Glob. Planet. Changes, Special NEESPI Program Issue, 56(3-4), 328-340

Alley RB (2000) The Younger Dryas cold interval as viewed from central Greenland. Quat. Sci. Rev., 19, 213-226

Alley RB and Ágústsdóttir AM (2005) The 8k event: cause and consequences of a major Holocene abrupt climate change. Quat. Sci. Rev., 24(10-11), 1123-1149 (doi: 101016/jquascirev 200412004)

Alley RB and 10 others (1993) Abrupt increase in Greenland snow accumulation at the end of the Younger Dryas event. Nature, 362, 527-529 (doi:10.1038/362527a0)

Alley RB and 5 others (1997) Holocene climatic instability; a prominent, widespread event 8,200 yr ago. Geology, 25, 483-486

Andreev AA and 5 others (2007) Environmental changes in the northern Altai during the last millennium documented in Lake Teletskoye pollen record. Quat. Res., 67, 394-399

Arnason B (1969) Equilibrium constant for fractionation of deuterium between ice and water. J. Phys. Chem., 73, 3491-3494.

Arz HW, Lamya F and Pätzoldb J (2006) A pronounced dry event recorded around $42 \mathrm{ka}$ in brine sediments from the northern Red Sea. Quat. Res., 66(3), 432-441, Bibcode:2006QuRes66432A (doi: 101016/jyqres200605006)

Beck HL and Bennett BG (2002) Historical overview of atmospheric nuclear weapons testing and estimates of fallout in the continental United States. Health Phys., 82(5), 591-608

Berzin N and Kungurtsev LV (1996) Geodynamic interpretation of Altai-Sayan geological complexes. Russ. Geol. Geophys., 37 (1), 56-73 (Russian)

Booth RK and 6 others (2005) A severe centennial-scale drought in midcontinental North America 4200 years ago and aarent global linkages. The Holocene, 15(3), 321-328 (doi: 101191/ $0959683605 \mathrm{hl} 825 \mathrm{ft})$

Bradley R (2000) 1000 years of climate change. Science, 288, 13531354

Bradley RS, Briffa KR, Cole J, Hughes MK and Osborn TJ (2003) The climate of the last millennium. In Alverson K, Bradley RS and Pedersen TF eds. Paleoclimate, global change and the future. Springer Verlag, Berlin, 105-141

Briffa KR and 6 others (1990) A 1,400-year tree-ring record of summer temperatures in Fennoscandia. Nature, 346, 434-439 (doi:10.1038/346434a0)

Bronk RC (2001) Development of the radiocarbon calibration program. Radiocarbon, 43(2A), 355-363
Butvilovskii VV (1993) Paleogeography of the late glacial and Holocene on Altai. Tomsk University Publisher, Tomsk (in Russian)

Carter MW and Moghissi AA (1977) Three decades of nuclear testing. Health Phys., 33, 55-71

Chun $\mathrm{CH}$, Jiangli $\mathrm{P}$, Zhaa X, Sub H and Jiaa Y (2011) Extraordinary floods related to the climatic event at 4200 BP on the Qishuihe River, middle reaches of the Yellow River, China. Quart. Sci. Rev., 30(3-4), 460-468 (doi: 101016/jquascirev201012007)

Clark ID and Fritz P (1997) Environmental isotopes in hydrogeology. Lewis Publishers, New York, $328 \mathrm{p}$

Claussen M-J and 5 others (1999) Simulation of an abrupt change in Saharan vegetation in the mid-Holocene. Geophys. Res. Lett., 26 (14), 2037-2040

Craig H (1957) Isotopic standards for carbon and oxygen and correction factors for mass-spectrometric analysis of carbon dioxide Geochim. Cosmochim. Acta, 12, 133-149

Dansgaard W (1964) Stable isotopes in precipitation. Tellus, 16(4), 436-468 (doi: 101111/j2153-34901964tb00181x)

Davis ME and Thompson LG (2006) An Andean ice-core record of a Middle Holocene mega-drought in North Africa and Asia. Ann. Glaciol., 43, 34-41 (doi: 103189/172756406781812456)

Davis ME, Thompson LG, Yao T and Wang N (2005) Forcing of the Asian monsoon on the Tibetan Plateau: evidence from high-resolution ice core and tropical coral records. J. Geophys. Res., 110 (D4), D04101 (doi: 101029/2004JD004933)

Eichler A and 7 others (2009) Temperature response in the Altai region lags solar forcing. Geophys. Res. Lett., 36, L01808 (doi: 101029/2008GL035930)

Eichler A and 5 others (2011) An ice-core based history of Siberian forest fires since AD 1250. Quat. Sci. Rev., 30, 1027-1034 (doi: 101016/jquascirev201102007 2005JD005819)

Froehlich K, Gibson JJ and Aggarwal P (2002) Deuterium excess in precipitation and its climatological significance. In Study of Environmental Changes Using Isotope Techniques, Proc. Intern. Conf. C\&S Pap. Ser. 13/P, International Atomic Energy Agency, Vienna, IAEA-CN-80/104, 54-65

Fujita K, Takeuchi N, Aizen V and Nikitin S (2004) Glaciological observations on the plateau of Belukha Glacier in the Altai Mountains, Russia from 2001 to 2003. Bull. Glaciol. Res., 21, 57-64

Grosswald MG (1980) Late quaternary ice sheet of northern Eurasia. Quat. Res., 13, 1-32

Grosswald MG, Kuhle M and Fastook JL (1994) Würm glaciation of Lake Issyk-Kul Area, Tian Shan Mts.: a case study in glacial history of Central Asia. Geo J., 33(2/3), 273-310

Haeberli W and Holzhauser H (2003) Alpine glacier mass changes during the past two millennia. Pages News, 1/11, 13-15

Haefeli R (1961) Contribution to the movement and the form of ice sheets in the Arctic and Antarctic. J. Glaciol., 3, 1133-1151

Hantemirov RM and Shiyatov SG (2002) A continuous multimillennial ring-width chronology in Yamal, northwestern Siberia. Holocene, 12(6), 717-726

Henderson KA and 5 others (2006) Temporal variations of accumulation and temperature during the past two centuries from Belukha ice core, Siberian Altai. J. Geophys. Res., 111, D03104 (doi: 101029/2005JD005819)

Herzschuh U (2006) Palaeo-moisture evolution in monsoonal central Asia during the last 50,000 Years. Quat. Sci. Rev., 25, 163-178

lizuka $Y$ and 9 others (2012) The rates of sea salt sulfatization in the atmosphere and surface snow of inland Antarctica. J. Geophys. Res., 117, D04308 (doi: 101029/2011JD016378)

IPCC (2014) WGIl AR5, Chapter 24, Asia (2492 Glaciers of Central Asia)

IPICS (2005) In Taylor K, Wolff KE, Alley RB, Brook E, Fitzpatrick J and Schwander J eds. International Partnerships in Ice Core Sciences (IGBP-PACES), Workshop Report. University of New Hampshire, Sterling, Virginia, $45 \mathrm{p}$

Jacoby GC, D'Arrigo RD and Davaajatms T (1996) Mongolian tree rings and 20th century warming. Science, 273, 771-773 
Jenk TM and 7 others (2006) Radiocarbon analysis in an Alpine ice core: record of anthropogenic and biogenic contributions to carbonaceous aerosols in the past (1650-1940). Atmos. Chem. Phys., 6, 5381-5390

Johnsen SJ and 14 others (1997) The $\delta^{18} \mathrm{O}$ record along the Greenland Ice Core Project deep ice core and the problem of possible Eemian climatic instability. J. Geophys. Res., 102 (C12), 26397-26410 (doi: 101029/97JC00167)

Joswiak DR (2008) Annual and decadal scale changes in atmospheric chemical composition determined from ice core records in association with meteorological factors and environmental changes in southwestern Siberia A Diss for PhD; College of Graduate Studies. University of Idaho $118 \mathrm{p}$

Jouzel J and 14 others (1996) Climatic interpretation of the recently extended Vostok ice records. Clim. Dyn., 12, 513-521

Kadota T, Fujita K, Seko K, Kayastha RB and Ageta Y (1997) Monitoring and prediction of shrinkage of a small glacier in the Nepal Himalaya. Ann. Glaciol., 24, 90-94

Kalugin I, Selegei V, Goldberg E and Seret G (2005) Rhythmic finegrained sediment deposition in Lake Teletskoye, Altai, Siberia, in relation to regional climate change. Quat. Int., 136, 5-13

Kang S, Wake CP, Qin D, Mayewski PA and Yao T (2000) Monsoon and dust signals in the Dasuopu firn core, central Himalaya. J. Glaciol., 46(153), 222-226

Kaspari S and 5 others (2008) Snow accumulation rate on Qomolangma (Mount Everest), Himalaya: synchronicity with sites across the Tibetan Plateau on 50-100 year timescales. J. Glaciol., 54(185), 343-352

Kobashi T, Severinghaus JP and Barnola J-M (2008) $4 \pm 15^{\circ} \mathrm{C}$ abrupt warming 11,270 a ago identified from traed air in Greenland ice Elsevier. Earth Planet. Sci. Lett., 268, 397-407

Kobashi T and 7 others (2011) High variability of Greenland surface temperature over the past 4000 years estimated from trapped air in an ice core. Geophys. Res. Lett., 38, L21501 (doi: 101029/ 2011GL049444)

Koerner RM and Fisher DA (1990) A record of Holocene summer climate from Canadian high Arctic ice core. Nature 343, 630631 (doi:10.1038/343630a0)

Koshkarova VL and Koshkarov AD (2004) Regional signatures of changing landscape and climate of northern central Siberia in the Holocene. Russ. Geol. Geophys., 45(6), 672-685 (in Russian)

Kuhle M (2004) The High Glacial (Last Ice Age and LGM) ice cover in High Central Asia. In Ehlers J, Gibbard PL eds. Development in Quaternary Science 2c (Quaternary Glaciation - Extent and Chronology, Part III: South America, Asia, Africa, Australia, Antarctica), Elsevier, Amsterdam, 175-199

Li B, Zhu AX, Zhang Y, Pei T, Qin CZ, Zhou C (2006) Glacier change over the past four decades in the middle Chinese Tien Shan. J. Glaciol., 52(178), 425-432 (doi: 10.3189/172756506781828557)

$\mathrm{Li} \mathrm{H}$ and $\mathrm{Ku} \mathrm{T} \mathrm{(2002)} \mathrm{Little} \mathrm{ice} \mathrm{age} \mathrm{and} \mathrm{medieval} \mathrm{warm} \mathrm{periods} \mathrm{in}$ Eastern China as read from the Speleothem Records. AGU, Fall Meeting 2002, abstract \#71C-09

Liu S and 7 others (2006) Glacier retreat as a result of climate change due to warming and increased precipitation in the Tarim River Basin, Northwest China. Ann. Glaciol., 43, 91-96

Lowe JJ and 7 others (2008) Precise dating and correlation of events in the North Atlantic region during the Last Termination: a revised protocol recommended by the INTIMATE group. Quat. Sci. Rev., 27, 6-17

Mackay AW and 6 others (2005) 1000 years of climate variability in central Asia: assessing the evidence using Lake Baikal (Russia) diatom assemblages and the alication of a diatom-inferred model of snow cover on the lake. Glob. Planet. Change, 46, 281-297

Malygina NS (2009) Reconstruction of atmospheric aerosol content over the Altai through the ice core records obtained from the saddle of Belukha Mountain. (PhD thesis, Institute of Water and Ecological Problems, Siberian filial Russian Academy of Science, Moscow, Russia) (in Russian)
Mann ME and 8 others (2009) Global signatures and dynamical origins of the Little Ice Age and Medieval Climate Anomaly. Science, 326, 1256-1260

Mayewski PA and Jeschke PA (1979) Himalayan and TransHimalayan glacier fluctuations since AD 1812. Arct. Alpine Res., 11(3), 267-287

Mayewski PA and 8 others (1993) Greenland ice core "signal" characteristics: an expanded view of climate change. J. Geophys. Res., 98(D7), 12,839-12,847

Mayewski PA and 12 others (1994) Changes in atmospheric circulation and ocean ice cover over the North Atlantic during the last 41,000 years. Science, 263, 1747-1751

Mayewski PA and 6 others (1997) Major features and forcing of highlatitude northern hemisphere atmospheric circulation using a 110,000-year-long glaciochemical series. J. Geophys. Res., 102, 26345-26366

Mayewski PA and 15 others (2004) Holocene climate variability. Quat. Res., 62, 243, 255

Mayewski PA, Aizen V, Qin D, Nakawo M and Schwikowski M (2005) Ice core Climate Archive Recovery Activity, on-line technical report. http://wwwclimatechangeumaineedu.

Meese DA and 8 others (1997) The Greenland Ice Sheet Project 2 depth - age scale: methods and results. J. Geophys. Res., 102 (C12), 26,411-26,423

Menounos B, Clague JJ, Osborn G, Luckman BH, Lakeman TR and Minkus R (2008) Western Canadian glaciers advance in concert with climate change circa $4.2 \mathrm{ka}$. Geophys. Res. Lett., 35, L07501 (doi: 10.1029/2008GL033172)

Mitchell TD, Carter TR, Jones PD, Hulme M and New M (2004) A comprehensive set of high-resolution grids of monthly climate for Europe and the globe: The observed record (1901-2000) and 16 scenarios (2001-2100) Tyndall Centre Working Paper 55, Tyndall Centre for Climate Change Research, University of East Anglia, Norwich, $30 \mathrm{p}$

Moore JC and 6 others (2012) Statistical extraction of volcanic sulphate from nonpolar ice cores. J. Geophys. Res., 117, D03306 (doi: 101029/2011JD016592)

Morrison J, Brockwell T, Merren T, Fourel F and Phillips AM (2001) On-line high-precision stable hydrogen isotopic analyses on nanoliter water samples. Anal. Chem., 73(15), 3570-3575

Naftz DL and 7 others (1996) Little Ice Age evidence from a southcentral North American ice core, U.S.A. J. Arct. Alpine Res., 28 (1), 35-41

Nakawo M, Chiba S, Satake H and Kinouchi S (1993) Isotopic fractionation during grain coarsening of wet snow, Ann. Glac., 18, 129-134

Nakazawa F and 6 others (2005) Dating of seasonal and annual layers in alpine glacier ice using pollen analysis. J. Glaciol., $\mathbf{5 1}$ (174), 453-490

Narama C, Shimamura Y, Nakayama D and Abdrakhmatov K (2006) Recent changes of glacier coverage in the western TerskeyAlatoo range, Kyrgyz Republic, using Corona and Landsat. Ann. Glac., 43, 223-229

O'Brien SR and 5 others (1995) Complexity of Holocene Climate as Reconstructed from a Greenland Ice Core. Science, 270, 1962-1964

Okamoto S and 9 others (2011) Re-evaluation of the reconstruction of summer temperatures from melt features in Belukha ice cores, Siberian Altai. J. Geophys. Res., 116, D02110 (doi: 101029/ 2010JD013977)

Okishev PA (2011) Relief and Oledenenie Russkogo Altaya [Book: The Relief and Glaciation of Russian Altai. Izdatel'stvo Tomskogo Gosudarstvennogo Universiteta]. Tomsk State University Publisher, $382 \mathrm{p}$ (in Russian)

Olivier S and 10 others (2003) Glaciochemical investigation of an ice core from Belukha glacier, Siberian Altai. Geophys. Res. Lett., 30(19), 2019

Olivier S and 8 others (2004) Plutonium from global fallout recorded in an ice core from the Belukha Glacier, Siberian 
Altai. Environ. Sci. Technol., 38(24), 6507-6512 (doi: 101021/ es0492900)

Olivier S and 8 others (2006) Temporal variations of mineral dust, biogenic tracers, and anthropogenic species during the past two centuries from Belukha ice core, Siberian Altai. J. Geophys. Res., 111, D05309 (doi: 101029/2005JD005830)

O'Neill JR (1968) Hydrogen and oxygen isotopic fractionation between ice and water. J. Phys. Chem., 72, 3683-3684

Osterberg EC, Handley M, Sneed SB, Mayewski PA and Kreutz K (2006) A high-resolution, continuous ice core melter system with discrete sampling for major ion, trace element, and stable isotope analyses. Environ. Sci. Technol., 40, 3355-3361

Ovchinnikov DV, Adamenko MF and Panushkina IP (2000) 1105-year tree-ring chronology in Altai region and its application for reconstruction of summer temperature. Geolines, 11, $121-122$

Palais JM, Germani MS and Zielinski GA (1992) Inter-hemispheric transport of volcanic ash from a 1259 AD volcanic eruption to the Greenland and Antarctic Ice Sheets. Geophys. Res. Lett., 19 (8), 801-804

Panyushkina IP, Adamenko MF and Ovchinnikov DV (2000) Dendroclimatic net over Altai Mountains as a base for numerical paleogeographic reconstruction of climate with high time resolution. In Problems of Climatic Reconstructions in Pleistocene and Holocene 2. Institute of Archaeology and Ethnography, Novosibirsk, 413-419

Parker AG and 5 others (2006) A record of Holocene climate change from lake geochemical analyses in southeastern Arabia. Quat. Res., 66(3), 465-476, Bib code:2006 Qu Res66465P (doi: 101016/jyqres200607001)

Paul F, Kaab A, Maisch M, Kellenberger TW and Haeberli W (2004) Rapid disintegration of Alpine glaciers observed with satellite data. Geophys. Res. Lett., 31(L21402) (doi: 101029/ 2004GL020816)

Peteet DM (1995) Global younger Dryas? Quat. Intl., 28, 93-104 (doi: 101016/1040-6182(95)00049-O)

Petit-Maire N, Sanlaville P and Zhong-Wei Y (1994) Changements globaux et paléomoussons: La zone de transition afroasiatique au cours des derniers 140000 ans. Géochronique, 50, 16-19

Pinglot JF and 13 others (2003) Ice cores from Arctic sub-polar glaciers: chronology and post-depositional processes deduced from radioactivity measurements. J. Glaciol., 49(164), 149-158

Qin D and 9 others (2001) Evidence for recent climate change from ice cores in the central Himalayas. Ann. Glaciol., 31, 153-158

Rasmussen SO and 15 others (2006) A new Greenland ice core chronology for the last glacial termination. J. Geophys. Res., 111, D06102 (doi: 10.1029/2005JD006079)

Raymond CF (1983) Deformation in the vicinity of ice divides. J. Glaciol., 29(103), 357-373

Reimer PJ and 27 others (2009) IntCal09 and Marine09 radiocarbon age calibration curves, 0-50,000 years cal BP. Radiocarbon, $\mathbf{5 1}$ (4), 1111-1150

Rhodes $\mathrm{T}$ and 10 others (1996) A Late Pleistocene-Holocene Lacustrine Record from Lake Manas, Zunggar (Northern Xinjiang, Western China). Palaeogeogr. Palaeoclimatol. Palaeoecol., 120, 105-121

Ricketts DR, Johnson TC, Brown ET, Rasmussen KA, and Romanovsky VV (2001) Trace element and stable isotope study of the Holocene paleoclimate of Lake Issyk-Kul. Palaeogeogr. Palaeoclimatol. Palaeoecol., 176, 207-227

Ruff $M$ and 5 others (2007) A gas ion source for radiocarbon measurements at $200 \mathrm{kV}$. Radiocarbon, 49, 307-314

Saarnisto M (2000) Climate variability during the last interglacialglacial cycle in NW Eurasia Abstracts of PAGES - PEPIII: Past Climate Variability Through Europe and Africa

Schwikowski M, Brutsch S, Gaggeler HW and Schotter U (1999) A high resolution air chemistry record from an alpine ice core:
Fiescherhorn glacier, Swiss Alps. J. Geophys. Res., 104( $\mathrm{N}$ D11), 13,709-13719

Shatravin VI (2000) Reconstruction of Pleistocene and Holocene glaciations in Tien-Shan and Pamir In Book: Pamir and Tien Shan "Glacier and Climate Fluctuations during the Pleistocene and Holocene" International Workshop, 22-23 July 2000, University of Bayreuth, Germany

Siebert L and Simkin T (2002) Volcanoes of the World: an Illustrated Catalog of Holocene Volcanoes and their Eruptions Smithsonian Institution, Global Volcanism Program, Digital Information Series, GVP-3. http://wwwvolcanosiedu/world/.

Siebert L, Simkin T and Kimberly P (2010) Volcanoes of the world, 3rd edn. University of California Press, Berkeley, $558 p$

Sigl $M$ and 10 others (2009) Towards radiocarbon dating of ice cores. J. Glaciol., 55(194), 985-996

Steffensen JP and 19 others (2008) High-resolution Greenland Ice core data show abrupt climate change Haens in few years. Science, 321(5889), 680-684 (doi: 101126/science1157707)

Stern D (2005) Global sulfur emissions from 1850 to 2000. Chemosphere, 58(2), 163-175

Stothers RB (1984) The great Tambora eruption in 1815 and its aftermath. Science, 224(1191), 1198 (doi: 101126/ science22446541191)

Surazakov AB and Aizen VB (2006) Estimating volume change of Mountain Glaciers using SRTM and topographic data. IEEE Trans. Geosci. Remote Sens., 44(10), 2991-2995

Synal H-A, Stocker M and Suter M (2007) MICADAS: a new compact radiocarbon AMS system. Nucl. Instrum. Methods Phys. Res., B259(1), 7-13

Szidat S and 6 others (2004) THEODORE, a two-step heating system for the EC/OC determination of radiocarbon $\left({ }^{14} \mathrm{C}\right)$ in the environment. Nucl. Instrum. Methods Phys. Res., B223-224, 829-836

Takeuchi N and 7 others (2004) A report on ice core drilling on the western plateau of Mt Belukha in the Russian Altai Mountains in 2003. Polar Meterol. Glaciol., 18, 121-133

Takeuchi $\mathrm{N}$ and 7 others (2014) The disappearance of glaciers in the Tien Shan Mountains in Central Asia at the end of Pleistocene. Quat. Sci. Rev., 103, 26-33 (doi:10.1016/j. quascirev.2014.09.006)

Taylor K and 6 others (1992) Ice-core dating and chemistry by directcurrent electrical conductivity. J. Glaciol., 38(130), 325-332

Taylor KC and 12 others (1997) The holocene-younger Dryas transition recorded at summit, Greenland. Science, 278, 825-827

Thompson LG and 8 others (1989) 100,000 year climate record from Qinghai-Tibetan Plateau ice cores. Science, 246(4929), 474-477

Thompson LG and 7 others (1995) Late glacial stage and holocene tropical ice core records from Huascarán, Peru. Science, 269, 47-50

Thompson LG and 9 others (1997) Tropical climate Qinghai-Tibetan ice core instability: the last glacial cycle. Science, 276, 18211825 (doi: 101126/science27653201821)

Thompson LG and 5 others (2000) A high-resolution millennial record of the South Asian Monsoon from Himalayan Ice cores. Science, 289, 1916-1919

Thompson LG and 5 others (2003) Tropical glacier and ice core evidence of climate change on annual to millennial time scales. Clim. Change, 59, 137-155

Tian L and 8 others (2006) Recent rapid warming trend revealed from the isotopic record in Muztagata ice core, eastern Pamirs. J. Geophys. Res., 111, D13103 (doi: 10.1029/2005JD006249)

UNEP/World Glacier Monitoring Service (2008) Glacier mass balance data 2005-2006

Valendik EN (1996) Temporal and spatial distribution of forest fires in Siberia. In Goldammer JG and Furyaev VV eds. Fire in Ecosystems of Boreal Eurasia. Kluwer Academic Publishers, Netherlands, 129-138 
Velichko AA and Isayeva LL (1992) Landscape types during the last glacial maximum. In Frenzel B, Pecsi B and Velichko AA eds. Atlas of Palaeoclimates \& Palaeoenvironments of the Northern Hemisphere. INQUA/Hungarian Academy of Sciences, Budapest, 59-60

Velichko AA and Kurenkova AA (1990) Landscapes of the Northern Hemisphere during the Late Glacial Maximum. In Soffer $O$ and Gamble G eds. The World at 18,000 BP. Unwin Hyman, London, 255-265

Velichko AA, Isayeva LL, Makeyev VM, Matishov GG and Faustova MA (1984) Late Pleistocene Glaciation of the Arctic Shelf and the reconstruction of Eurasia ice sheets. In Velichko AA ed. Late Quaternary Environments of the Soviet Union. Longman Group Ltd, London, 35-44

Velichko AA and 5 others (2002) Climate changes in east Europe and Siberia at the late Glacial-Holocene transition. Quat. Int., 91(N1), 75-99

Vinther BM and 13 others (2009) Holocene thinning of the Greenland ice sheet. Nature, 461, 385-388 (doi: 101038/ nature08355)

Vorob'ev YL, Akimov VA and Sokolov YI (2004) Forest fires on the territory of Russia: state and problems. Ministry of Extreme Situations, Russia DAKS-Press, Moscow, 312 p

Whitlow S, Mayewski P, Dibb J, Holdsworth G and Twickler M (1994) An ice-core based record of biomass burning in the Arctic and Subarctic, 1750-1980. Tellus B, 46(3), 234-242

Winkler MG and Wang PK (1993) The late-Quaternary vegetation and climate of China. In Wright HE, Jr and 5 others eds. Global Climates Since The Last Glacial Maximum. University of Minnesota Press, Minneapolis, 221-261

Yalcin K, Wake CP, Kreutz KJ and Whitlow SI (2006) A 1000-yr record of forest fire activity from Eclipse Icefield, Yukon, Canada. The Holocene, 16(2), 200-209

Yang X, Rost K, Lehmkuhl F, Zhenda Z and Dodson J (2004) The evolution of Dry lands in Northern China and in the Republic of Mongolia since the last glacial maximum. Quat. Int., 118-119, 69-85

Yao T and Yang M (2004) ENSO events recorded in Tibetan ice cores. Dev. Paleoenviron. Res., 9, 163-180

Zielinski GA (1995) Stratospheric loading and optical depth estimates of explosive volcanism over the last 2100 years derived from the Greenland Ice Sheet Project 2 ice core. J. Geophys. Res., 100(D10), 20,937-20,955

Zielinski GA and 8 others (1994) Record of volcanism since 7000 BC from the GISP Greenland ice core and implications for the volcano-climate system. Science, 264(5161), 948-952

Zoller H (1960) Pollenanalytische Untersuchungen zur Vegetationsgeschichte der insubrischen Schweiz. Denkschriften der Schweizerischen Naturforschenden Gesellschaft, 83, 45-156 (in German)

\section{APPENDIX}

CCI UM Climate Change Institute at the University of Maine, USA

ISU Idaho State University, Environmental

Monitoring Laboratory, USA

NICL National Ice Core Laboratory, USA

NIPR National Institute for Polar Research, Japan

NU Nagoya University, Japan

RIHN Research Institute for Humanity and Nature, Japan

UI University of Idaho, USA

Bl2003 ice core drilled to bedrock on the Western Belukha Plateau at $4115 \mathrm{~m}$ a.s.I. by US/ Japanese team in 2003 (current research; Takeuchi and others, 2004; Aizen and others, 2005)

$\mathrm{Bl} 2001$ ice core (not to bedrock) drilled on the saddle between the east and west Belukha Peaks at $4062 \mathrm{~m}$ a.s.l. by Swiss team in 2001 (Olivier and others, 2003)

GISP-2 ice core records from Greenland Ice Sheet Project Two (Alley, 2000; Kobashi and others, 2011; Vinther and others, 2009)

${ }^{14} \mathrm{C} \quad$ radiocarbon records

$\delta^{18} \mathrm{O} / \delta \mathrm{D} \quad$ stable isotopes records

${ }^{3} \mathrm{H}$ radiogenic measurements of tritium concentration

AWE1 first short and abrupt warming event

BA Bølling- Allerød period

$\mathrm{HCO} \quad H o l o c e n e$ Climate Optimum

IP Industrial Period

LGM Last Glacial Maximum

LIA Little Ice Age

MoWP Modern Warm Period

MWP Medieval Warm Period

PB Pre Boreal

PBO Pre Boreal Oscillation event

PI Pre-Industrial Period

PWP Pre-Medieval Warm Period

ReWP Recent Warm Period

SCD severe centennial drought

$\mathrm{SH} \quad$ Siberian High

YD Younger Dryas 